Европейская

Экономическая

Комиссия

Евростат

EKMT

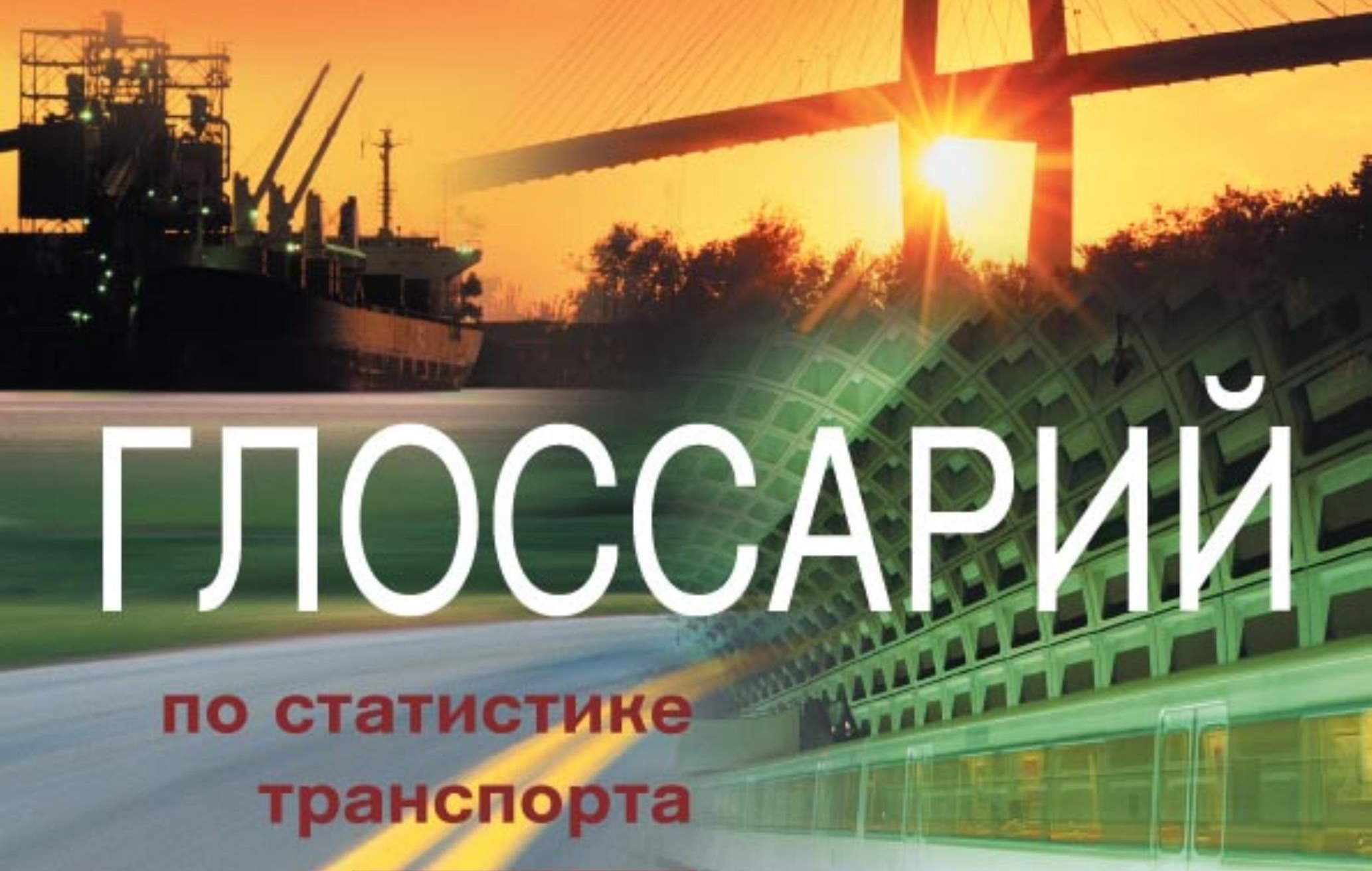

\title{
TPЕТЬЕ ИЗДАНИЕ
}

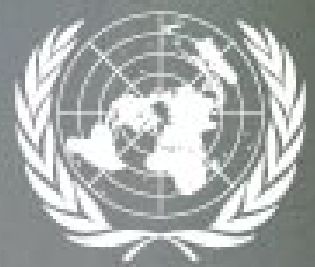

ОБЪЕДИНЕННЫЕ НАЦИЙ 


\section{ЕВРОПЕЙСКАЯ ЭКОНОМИЧЕСКАЯ КОМИССИЯ}
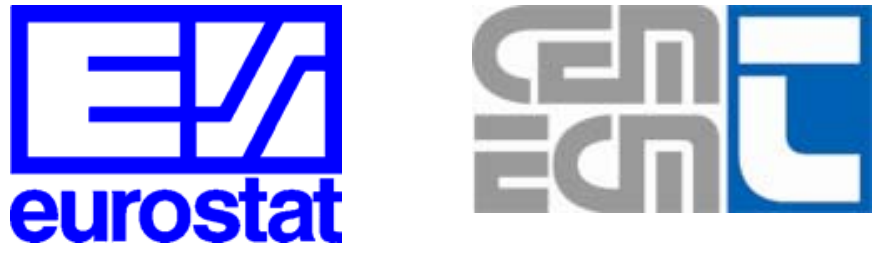

\section{МЕЖСЕКРЕТАРИАТСКАЯ РАБОЧАЯ ГРУППА ПО СТАТИСТИКЕ ТРАНСПОРТА (МРГ)}

\section{Глоссарий по \\ статистике транспорта}

Третье издание

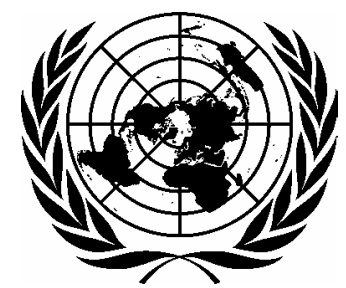


Условные обозначения документов Организации Объединенных Наций состоят из прописных букв и цифр. Когда такое обозначение встречается в тексте, оно служит указанием на соответствующий документ Организации Объединенных Наций.

Употребляемые обозначения и изложение материала в настоящем издании не означают выражения со стороны Секретариата Организации Объединенных Наций какого бы то ни было мнения относительно правового статуса страны, территории, города или района, или их властей, или относительно делимитации их границ. 


\section{ВЫРАЖЕНИЕ ПРИЗНАТЕЛЬНОСТИ}

Настоящее издание было подготовлено Межсекретариатской рабочей группой (МРГ.Транс), в состав которой входят г-н Мирослав Н. Йованович (ЕЭК ООН), Марио Баррето (ЕКМТ) и Ханс Стрелов (Евростат).

Консультации по различным главам были проведены с целым рядом национальных экспертов и представителей международных и неправительственных организаций. Различные этапы процесса пересмотра были проанализированы и одобрены членами Рабочей группы по статистике транспорта (WP.6) ЕЭК ООН.

На разных этапах подготовки пересмотренной главы по железнодорожному транспорту были получены замечания от г-на Жиля Гардиоля (МСЖД), Эрика Гриба (Статистическое управление Дании) и Ларса Сьёберга ("Банверкет", Швеция), которые также внесли значительный конкретный вклад в эту работу и которым выражается глубокая признательность за их помощь. Вопрос о пересмотре определений в главе по железнодорожному транспорту обсуждался на совещании Рабочей группы по железнодорожному транспорту, которое было организовано Евростатом в Люксембурге в октябре 2002 года.

Полностью пересмотренная глава по морскому транспорту была подготовлена Евростатом при содействии компетентных национальных органов. Главным консультантом и советником был г-н Ричард Бутчарт (компания "Артемис информейшн менеджмент"). Пересмотренные определения были одобрены на совещании Рабочей группы по морскому транспорту, состоявшемся в Люксембурге в январе 2003 года.

Исследовательской работой, общей координацией деятельности и редактированием занималась г-жа Сюзанна Гаравана Актипис (Евростат). 



\section{СОДЕРЖАНИЕ}

CTp.

Введение

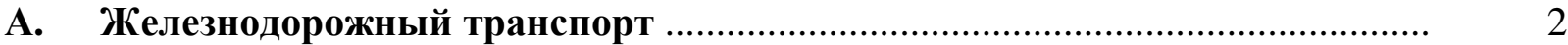

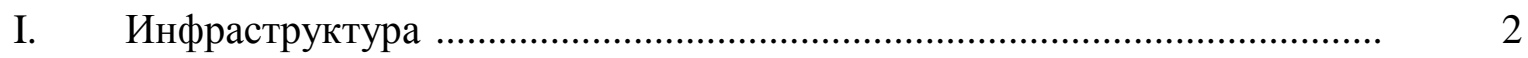

II. $\quad$ Транспортное оборудование (транспортные средства) ........................... 6

III. Предприятия, экономическая деятельность и сфера занятости .............. 14

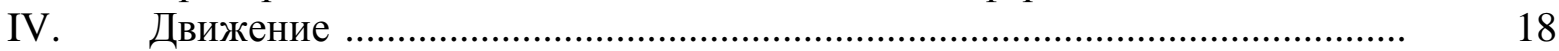

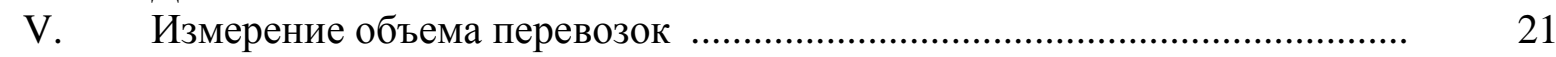

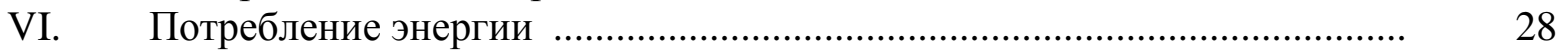

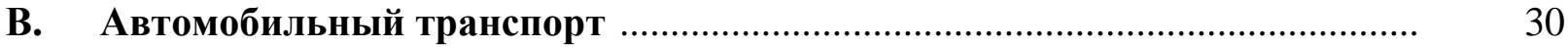

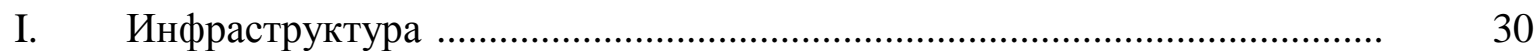

II. $\quad$ Транспортное оборудование (транспортные средства) .......................... 32

III. Предприятия, экономическая деятельность и сфера занятости .............. 38

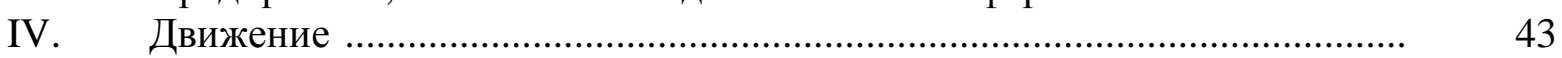

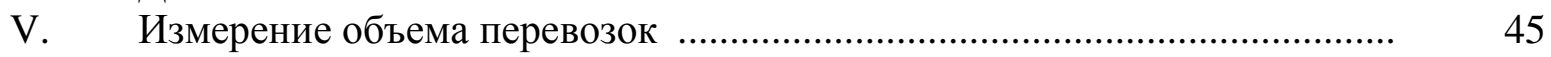

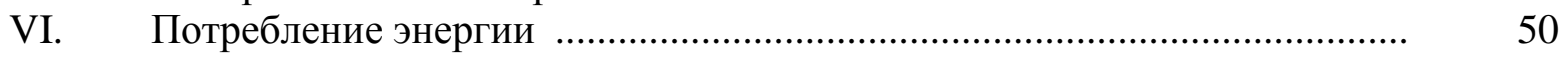

VII. Дорожно-транспортные происшествия ……........................................... 52

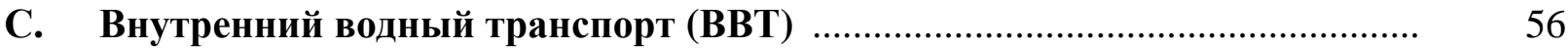

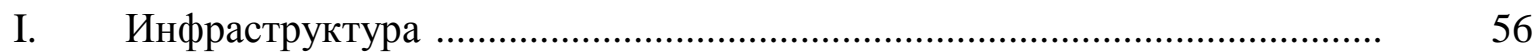

II. Транспортное оборудование (судно) ................................................. 57

III. Предприятия, экономическая деятельность и сфера занятости .............. $\quad 61$

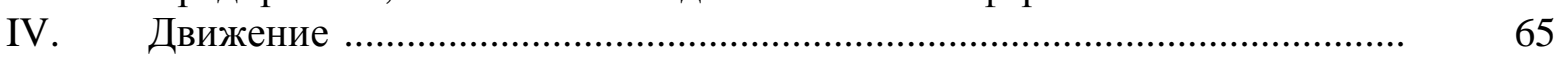

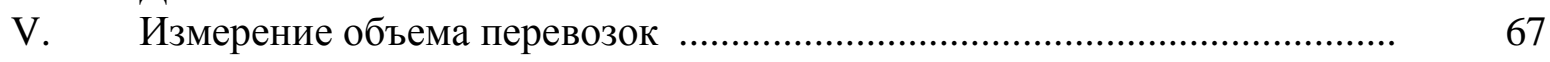

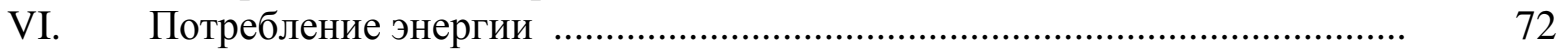

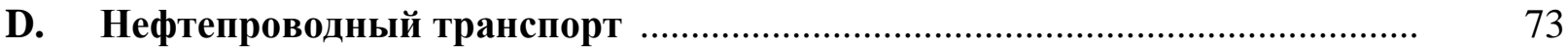

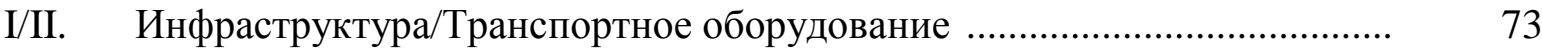

III. Предприятия, экономическая деятельность и сфера занятости .............. 74

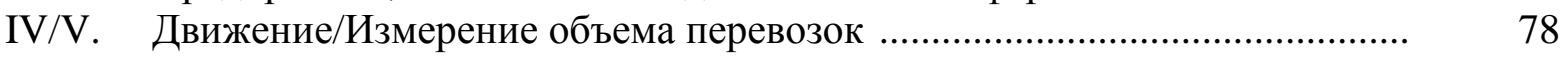

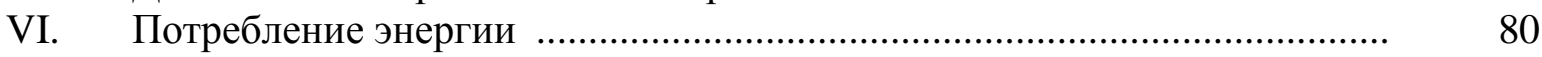


Cтp.

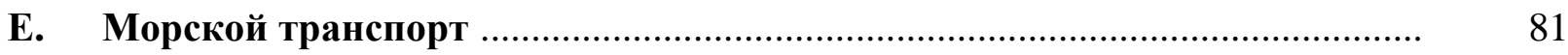

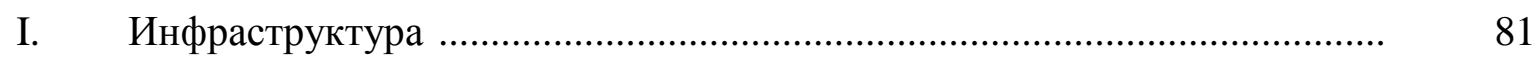

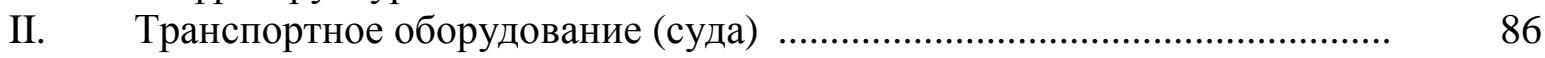

III. Предприятия, экономическая деятельность и сфера занятости .............. 94

IV. Движение ........................................................................................ 101

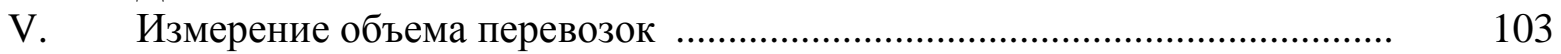

VI. Потребление энергии ....................................................................... 112

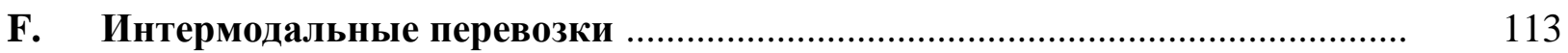

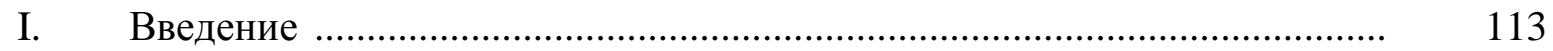

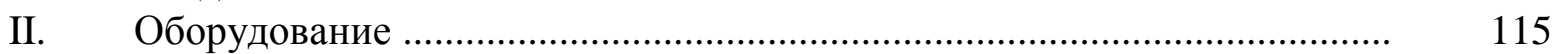

Предметный указатель ............................................................................ 119 


\section{ВВЕДЕНИЕ}

Глоссарий по статистике транспорта был впервые опубликован в 1994 году в целях оказания помощи странам-членам в процессе сбора данных по транспорту, осуществляемого ЕЭК ООН, ЕКМТ и Евростатом с использованием Общего вопросника.

Настоящее третье издание является результатом активного сотрудничества трех вышеупомянутых организаций, которые через посредство Межсекретариатской рабочей группы прилагали постоянные усилия для того, чтобы обеспечить согласование транспортной статистики на международном уровне. Сейчас Глоссарий включает 533 определения и служит справочным пособием для всех, кто связан со статистикой транспорта. Соблюдение принципов, отраженных в этих определениях, позволит существенным образом повысить качество данных и их сопоставимость.

Полностью пересмотренная глава по железнодорожному транспорту является итогом сложного процесса анализа текущего положения на рынке железнодорожных перевозок и продолжительного обмена мнениями между экспертами. Глава по морскому транспорту была также полностью пересмотрена и значительно расширена. Все пересмотренные варианты учитывают самые последние европейские нормативные акты в каждой конкретной области, а также определения, используемые в рамках соответствующих международных организаций (таких, например, как Международный союз железных дорог и Международная морская организация). В главу по автомобильному транспорту был добавлен абсолютно новый раздел по безопасности дорожного движения, а также четыре новые позиции, касающиеся транспортного оборудования. После опубликования Глоссария на английском, русском и французском языках, возможно, он будет переведен на все другие языки Европейского союза.

В рамках МРГ.Транс будет продолжена работа над терминологией, связанной со статистикой аварийности на железных дорогах, статистикой внутреннего водного и нефтепроводного транспорта, а также статистикой воздействия транспорта на окружающую среду, в целях ее возможного включения в будущие издания Глоссария. Третье издание Глоссария по статистике транспорта будет помещено в Интернете на адресных страницах трех организаций (см. ниже).

Любую информацию об этой публикации можно получить через следующих контактных лиц: 


\section{ЕВРОПЕЙСКАЯ ЭКОНОМИЧЕСКАЯ КОМИССИЯ ОРГАНИЗАЦИИ ОБЪЕДИНЕННЫХ НАЦИЙ (ЕЭК ООН)}

Miroslav N. Jovanović, Palais des Nations, CH-1211 Geneva 10

Электронная почта: Miroslav.Jovanović@ unece.org, Интернет: http://www.unece.org

\section{ЕВРОПЕЙСКАЯ КОНФЕРЕНЦИЯ МИНИСТРОВ ТРАНСПОРТА (ЕКМТ)}

Mario Barreto, 2/4 rue Louis David, F-75016 Paris

Электронная почта: Mario.Barreto@oecd.org, Интернет: http://www.oecd.org/cem

\section{EBPOCTAT}

Hans Strelow, Transport Statistics Unit, L-2920 Luxembourg

Электронная почта: Hans.Strelow @ cec.eu.int, Интернет: http://europa.eu.int/comm/eurostat/

\section{Примечание}

Выделенные курсивом пояснительные замечания, которые приводятся в отдельных случаях под определениями, имеют целью облегчить заполнение вопросников странами и непосредственно в определения не входят.

\section{А. ЖЕЛЕЗНОДОРОЖНЫЙ ТРАНСПОРТ}

Метро и легкий железнодорожный транспорт исключаются, если не указано иное. Трамваи включены в главу по автомобильному транспорту.

\section{A.I. ИНФРАСТРУКТУРА}

\section{A.I-01. Железная дорога}

Линия сообщения, представляющая собой рельсовый путь и предназначенная исключительно для железнодорожных транспортных средств.

Линия сообщения представляет собой часть пространства, оборудованного для осуществления перевозок.

\section{A.I-02. Метро}

Электрическая железная дорога для перевозки пассажиров, отличающаяся большой пропускной способностью, исключительным правом преимущественного проезда поездов, использованием многовагонных составов, высокой скоростью движения, быстрым ускорением, сложной системой сигнализации для обеспечения регулярности движения поездов и высоким расположением платформ. Метро также характеризуется частым расположением станций, что, как правило, означает расстояние в 700-1 200 м между станциями.

Понятие "высокой скорости" используется для сравнения с трамваями и легким железнодорожным транспортом и здесь означает приблизительно $30-40$ км/ч в 
случае небольших расстояний и 40-70 км/ч при более значительных расстояниях. Известно также как "подземка", "городская железная дорога" или "метрополитен".

\section{A.I-03. Легкий железнодорожный транспорт}

Железная дорога для перевозки пассажиров, на которой часто используются электрические рельсовые вагоны, эксплуатируемые по отдельности или в составе поездов небольшой длины и передвигающиеся по закрепленным сдвоенным железнодорожным путям. Расстояние между станциями/остановками обычно составляет менее 1200 м.

По сравнению с метро на легком железнодорожном транспорте используются более легкие конструкиии, он предназначен для меньших объемов движения и обычно для более низких скоростей.

Иногда трудно провести четкое различие между легким железнодорожным транспортом и трамваями; трамваи обычно не отделены от потоков автомобильного движения, тогда как легкий железнодорожный транспорт может быть отделен от других систем.

\section{A.I-04. Железнодорожная сеть}

Все железные дороги в данном районе.

В нее не входят участки дорог или водных путей, даже если железнодорожный подвижной состав может перевозиться по таким марирутам, например, на прицепах для перевозки вагонов или на железнодорожных паромах. Исключаются железнодорожные линии, используемые только для туристических иелей, а также железные дороги, которые проложены исключительно для обслуживания шахт, лесоразработок либо других промышленных или сельскохозяйственных предприятий и которые закрыты для перевозок общегго пользования.

\section{A.I-05. Железнодорожный путь}

Пара рельсов, по которым могут передвигаться железнодорожные транспортные средства.

\section{А.І-6. Ширина колеи}

Расстояние между двумя рельсами, измеренное между внутренними краями головок рельсов.

В настоящее время используются железнодорожные колеи следующей ширины:

Нормальная колея: $\quad 1,435$ м 
$\begin{array}{ll}\text { Широкая колея: } & 1,524 \text { м (например, Финляндия) } \\ & 1,600 \text { м (например, Ирландия) } \\ & 1,668 \text { м (например, Португалия) } \\ \text { Узкая колея: } & 0,60 \text { м; 0,70 м; 0,75 м; 0,76 м; 0,785 м; 0,90 м; 1,00 м. }\end{array}$

Иногда вместо термина "путь широкой колеи" используется термин "ширококолейная железная дорога".

\section{А.I-07. Железнодорожный габарит приближения строений}

Очертание контура, через который должны проходить железнодорожное транспортное средство и его груз, с учетом туннелей и путевых препятствий.

По согласованию с МСЖД используются следующие три международных габарита:

ГАБАРИТ А:

общая высота 3,85 м над рельсовым путем и 1,28 м с каждой сторонь оси рельсовой колеи.

ГАБАРИТ В:

общая высота 4,08 м над рельсовым путем и 1,28 м с каждой стороны оси рельсовой колеи.

\section{ГАБАРИТ С:}

общая высота 4,65 м над рельсовым путем и 1,45 м с каждой стороны оси рельсовой колеи.

Другим габаритом, имеющим особое значение, является ГАБАРИТ В+: общая высота составляет 4,18 м над рельсовым путем и 1,36 м с каждой стороны оси рельсовой колеи.

Вообще существует много других габаритов, признанных на железнодорожных cетяx.

\section{A.I-08. Главный путь}

Путь, обеспечивающий непрерывность линии на всем протяжении и предназначенный для движения поездов между станциями или местностями, указанными в тарифах в качестве независимых пунктов отправления или прибытия для перевозки пассажиров или грузов.

\section{А.I-09. Электрифицированный путь}

Путь, снабженный воздушным контактным проводом или контактным рельсом для обеспечения электрической тяги. 


\section{A.I-10. Подъездные железнодорожные пути}

Железнодорожные пути, отходящие от главных железнодорожных путей.

Протяженность подъездных железнодорожных путей включается в протяженность железнодорожных путей, управляемых управляюшим инфраструктурой, за исключением частных подъездных железнодорожных путей.

\section{A.I-11. Частный подъездной железнодорожный путь}

Путь или комплекс путей, которые не управляются управляющим инфраструктурой, но связаны с путем управляющего инфраструктурой таким образом, что
a) железнодорожные предприятия или вспомогательные подразделения могут осуществлять необходимую деятельность;
b) промышленные, коммерческие или портовые и т.д. объекты или группы объектов могут обслуживаться железной дорогой без перегрузки грузов.

\section{A.I-12. Линия}

Один или несколько расположенных рядом главных путей, образующих маршрут между двумя пунктами. Если участок сети состоит из двух или нескольких параллельных линий, то учитывается столько линий, сколько имеется маршрутов, для исключительного обслуживания которых предназначены пути.

\section{А.I-13. Специализированная высокоскоростная линия}

Линия, которая специально построена для обеспечения на ее основных участках движения со скоростью, как правило, не менее 250 км/ч.

Высокоскоростные линии могут включать примыкающие пути, в частности железнодорожные узль с расположенными на них центральными городскими станциями, где скорость движения может регулироваться с учетом местных условий.

\section{A.I-14. Модернизированная высокоскоростная линия}

Обычная железнодорожная линия, которая специально модернизирована для обеспечения на ее основных участках движения со скоростью порядка 200 км/ч.

Они включают специильно модернизированные высокоскоростные линии, которые имеют особые характеристики в силу топографических, рельефных или градостроительных ограничений и на которых скорость должна регулироваться применительно к каждому случаю. 


\section{A.I-15. Протяженность эксплуатируемых линий}

Общая протяженность линии, эксплуатируемой с целью осуществления пассажирских перевозок и/или грузовых перевозок.

Если линия эксплуатируется одновременно несколькими железнодорожными компаниями, то она учитывается только один раз.

\section{A.I-16. Электрифицированная линия}

Линия с одним или несколькими электрифицированными главными путями.

Прилегающие к станцииям участки линий, электрифищированные только для осуществления маневровых операчий, но не на всем протяжении линии до следующей станции, учитываются в качестве неэлектрифицированных линий.

\section{A.I-17. Виды электрической энергии}

В настоящее время используются следующие виды электрического тока:

- $\quad$ переменный ток

$25000 \mathrm{~B}, 50 \Gamma^{2}$
$15000 \mathrm{~B}, 16^{2 / 3} \Gamma Ц$
$3000 \mathrm{~B}$
$1500 \mathrm{~B}$
$750 \mathrm{~B}$
$660 \mathrm{~B}$
$630 \mathrm{~B}$

\section{A.I-18. Максимальная эксплуатационная скорость}

Самая высокая скорость, допускаемая для коммерческих перевозок с учетом технических характеристик инфраструктуры.

\section{А.II. ТРАНСПОРТНОЕ ОБОРУДОВАНИЕ (ТРАНСПОРТНЫЕ СРЕДСТВА)}

\section{A.II-01. Железнодорожное транспортное средство}

Подвижное оборудование, передвигающееся исключительно по рельсам, которое либо использует собственную тягу (тяговые транспортные средства), либо буксируется другим транспортным средством (пассажирские вагоны, прицепные вагоны моторвагонного поезда, багажные и товарные вагоны).

В статистические данные хозяйствующего субъекта на железнодорожном транспорте включаются следуюшие транспортные средства:

а) все железнодорожные транспортные средства, принадлежашие хозяйствующему субъекту на железнодорожном транспорте, а также 
средства, взятые им внаем и фактически находящиеся в его распоряжении, включая те транспортные средства, которые ремонтируются или ожидают ремонта либо содержатся в парке в рабочем или нерабочем состоянии, а также иностранные транспортные средства, находящиеся в распоряжении этого хозяйствующего субъекта, и его транспортные средства, временно находящиеся в порядке обычной эксплуатащฺи за гранищей;

b) товарные вагоны, принадлежащие частным владельиам, т.е. товарные вагоны, не принадлежашие хозяйствующему субъекту на железнодорожном транспорте, но допущенные к перевозкам за счет этого субъекта при соблюдении указанных условий, а также товарные вагоны, отданные этим хозяйствующим субъектом внаем третьим сторонам и эксплуатируемые в качестве товарных вагонов, принадлежащих частным владельцам.

Из статистических данных хозяйствующего субъекта на железнодорожном транспорте исключаются транспортные средства, которые не находятся в его распоряжении, т.е.:

а) иностранные транспортные средства или транспортные средства, не принадлежащие хозяйствующему субъекту на железнодорожном транспорте, которые эксплуатируются в железнодорожной сети;

b) транспортные средства, которые отданы внаем или каким-либо иным образом переданы в распоряжение других хозяйствующих субъектов на железнодорожном транспорте;

c) транспортные средства, зарезервированнье исключительно для технических перевозок или предназначенные для продажи, передачи на слом или списания.

\section{А.II-02. Высокоскоростное железнодорожное транспортное средство}

Железнодорожное транспортное средство, предназначенное для движения с крейсерской скоростью не менее 250 км/ч на специализированных высокоскоростных железнодорожных линиях.

На некоторых участках в силу местных условий крейсерская скорость может быть ниже.

\section{A.II-03. Высокоскоростное железнодорожное транспортное средство с наклонным кузовом}

Железнодорожное транспортное средство с системой наклона кузова, предназначенное для движения с крейсерской скоростью не менее 200 км/ч на модернизированных высокоскоростных железнодорожных линиях. 
На некоторых участках в силу местных условий крейсерская скорость может быть ниже.

\section{A.II-04. Обычное высокоскоростное железнодорожное транспортное средство}

Любое железнодорожное транспортное средство, которое специально не предназначено для движения по специализированным или модернизированным высокоскоростным линиям, но все же способно развивать максимальную крейсерскую скорость приблизительно 200 км/ч.

\section{А.II-05. Поездная секция}

Неделимый блок, состоящий из автомотрисы (автомотрис) и прицепного (прицепных) вагона (вагонов) либо из локомотива (локомотивов) и пассажирского железнодорожного транспортного средства (пассажирских железнодорожных транспортных средств).

В эту категорию включены поездные секиии, которые технически являются разъемными, но обычно сохраняются в одной и той же конфигурации.

Поездная секиия может сиееляться с другой секичией.

Иногда тяговое усилие может распределяться по всей поездной секциии.

\section{A.II-06. Тяговое транспортное средство}

Транспортное средство, оборудованное первичным двигателем и двигателем или только двигателем и предназначенное исключительно для буксировки других транспортных средств ("локомотив") или для буксировки других транспортных средств и перевозки пассажиров и/или грузов ("автомотриса").

\section{А.II-07. Локомотив}

Тяговое железнодорожное транспортное средство, усилие которого на тяговом крюке составляет не менее 110 кВт, оборудованное первичным двигателем и двигателем или только двигателем и используемое лишь для буксировки железнодорожных транспортных средств.

Мотовозы из этой категории исключаются.

\section{A.II-08. Мотово3}

Тяговое железнодорожное транспортное средство, усилие которого на тяговом крюке составляет менее 110 кВт. 
Обычно используется для выполнения маневровых работ или для продвижения рабочих поездов и осуществления перевозок на короткие расстояния либо малотоннажных перевозок с иелью обслуживания терминалов.

\section{A.II-09. Паровоз}

Цилиндровый или турбинный локомотив, источником энергии которого является пар, независимо от вида используемого топлива.

\section{А.II-10. Электровоз}

Локомотив с одним или несколькими электродвигателями, питаемыми электрическим током, подводимым главным образом по контактному проводу или контактному рельсу либо поступающим от находящихся на локомотиве аккумуляторов.

К категории электровозов относятся оборудованные таким образом локомотивы, снабженные также энергетической установкой (дизельной или иной) для питания током электродвигателя, когда этот ток нельзя получать от контактного провода или контактного рельса.

\section{A.II-11. Тепловоз}

Локомотив, основным источником энергии которого является дизельный двигатель, независимо от типа установленной передачи.

Однако дизель-электрические локомотивы, оборудованные также для получения электроэнергии, подводимой по контактному проводу или по контактному рельсу, относятся к категории электровозов.

\section{A.II-12. Автомотриса}

Тяговое железнодорожное транспортное средство, сконструированное для перевозки по железной дороге пассажиров или грузов. Определение различных категорий локомотивов (электровозы, тепловозы) применяется с соответствующими изменениями к автомотрисам.

Блок, состоящий из автомотрис и прищепных вагонов моторвагонного поезда, может называться

- "многосекиионным", если он модульного типа;

- "поездной секцией", если он стационарного типа.

В статистике механических транспортных средств каждая автомотриса в неразъемной секции учитывается отдельно; в статистике пассажирских транспортных средств и грузовых транспортных средств каждый кузов, 
оборудованный для перевозки пассажсиров или грузов, учитывается в качестве одной единищьл.

\section{A.II-13. Пассажирское железнодорожное транспортное средство}

Железнодорожное транспортное средство для перевозки пассажиров, даже если в нем имеется одно или несколько специальных отделений или специальных мест для багажа, грузовых мест, почты и т.д.

К этим транспортным средствам относятся такие специальные транспортные средства, как спальные вагоны, вагоны-салоны, вагоны-рестораны и санитарные вагоны. Каждое отдельное транспортное средство неразъемной секиии для перевозки пассажиров учитывается в качестве пассажирского железнодорожного транспортного средства. В эту категорию включены автомотрисы, предназначенные для пассажирских перевозок.

\section{А.II-14. Прицепной вагон моторвагонного поезда}

Нетяговое пассажирское железнодорожное транспортное средство, сцепленное с одной или несколькими автомотрисами.

Транспортные средства, используюшиеся для грузовых перевозок, даже если они буксируются автомотрисой, считаются товарными вагонами.

\section{A.II-15. Пассажирский вагон}

Пассажирское железнодорожное транспортное средство, за исключением автомотрисы или прицепного вагона моторвагонного поезда.

\section{А.II-16. Число сидячих и спальных мест}

Число сидячих и спальных мест, имеющихся в пассажирском транспортном средстве, когда оно используется по назначению.

Из этой категории исключаются места в вагонах-ресторанах и купе-буфетах.

\section{A.II-17. Число стоячих мест}

Число разрешенных стоячих мест, имеющихся в пассажирском транспортном средстве, когда оно используется по назначению.

\section{A.II-18. Багажный вагон}

Нетяговое железнодорожное транспортное средство, входящее в состав пассажирских или грузовых поездов и используемое поездной бригадой в случае необходимости также для перевозки багажа, грузовых мест, велосипедов и т.д. 
Транспортные средства, имеющие одно или несколько купе для пассажиров, должны учитываться не в качестве багажных вагонов, а в качестве пассажирских железнодорожных транспортных средств. Почтовые вагоны, принадлежашие железнодорожным компаниям, считаются багажными вагонами, если они не имеют купе для пассажиров.

\section{A.II-19. Товарный вагон}

Железнодорожное транспортное средство, обычно предназначенное для перевозки грузов.

В эту категорию включаются автомотрисы и прицепные вагоны моторвагонного поезда, оборудованные только для перевозки грузов.

\section{A.II-20. Товарный вагон, принадлежащий хозяйствующего субъекту на железнодорожном транспорте}

Любой товарный вагон, принадлежащий хозяйствующего субъекту на железнодорожном транспорте.

Из этой категории исключаются товарные вагоны, принадлежащие частным владельиам.

\section{A.II-21. Товарный вагон, принадлежащий частному владельцу}

Вагон, не принадлежащий хозяйствующему субъекту на железнодорожном транспорте, но находящийся в его распоряжении и допущенный к перевозкам за его счет при соблюдении специальных условий, либо товарный вагон, отданный хозяйствующему субъекту на железнодорожном транспорте внаем третьим сторонам.

\section{A.II-22. Крытый вагон}

Товарный вагон, характеризуемый закрытой конструкцией (сплошные стенки до самого верха и крыша) и безопасностью, которую он обеспечивает перевозимым в нем грузам (возможность закрытия вагона на замок и опломбирования).

В эту категорию включаются товарные вагоны с открывающейся крышей, а также изотермические и отапливаемые вагоны и вагоны-ледники.

\section{A.II-23. Изотермический вагон}

Крытый вагон, кузов которого имеет термоизолирующие стенки, двери, пол и крышу, что ограничивает теплообмен между внутренней и наружной поверхностью кузова таким образом, чтобы по общему коэффициенту теплопередачи 
(коэффициент К) транспортное средство могло быть отнесено к одной из двух следующих категорий:

$\mathrm{I}_{\mathrm{N}}=$ Обычное изотермическое транспортное средство,, характеризующееся коэффициентом $\mathrm{K}$, не превышающим $0,7 \mathrm{BT} / \mathrm{m}^{2}{ }^{\circ} \mathrm{C}$

$\mathrm{I}_{\mathrm{R}}=$ Изотермическое транспортное средство с усиленной изоляцией, характеризующееся коэффициентом $\mathrm{K}$, не превышающим $0,4 \mathrm{~B} \mathrm{~T} / \mathrm{m}^{2}{ }^{\circ} \mathrm{C}$

\section{А.II-24. Вагон-ледник}

Изотермический вагон, в котором используется источник холода (естественный лед с добавлением или без добавления соли; эвтектические плиты; сухой лед с приспособлением, позволяющим регулировать его сублимацию, или без такового; сжиженные газы с устройством для регулирования испарения или без такового и т.д.), не являющийся механической или "абсорбционной" установкой.

Такой вагон позволяет при средней наружной температуре $+30^{\circ} \mathrm{C}$ понижать температуру внутри порожнего кузова и затем ее поддерживать

- $\quad$ на уровне не более $+7^{\circ} \mathrm{C}$ для класса $A$;

- н на уровне не более - $10^{\circ} \mathrm{C}$ для класса B;

- н на уровне не более $-20^{\circ} \mathrm{C}$ для класса C; и

-

с помощью соответствующих хладагентов и устройств.

\section{A.II-25. Вагон-рефрижератор}

Изотермический вагон, имеющий индивидуальную или общую для нескольких транспортных единиц холодильную установку (механический компрессор, "абсорбционную" установку и т.д.).

Такой вагон позволяет при средней наружной температуре $+30^{\circ} \mathrm{C}$ понижать температуру внутри порожнего кузова и затем постоянно поддерживать ее следующим образом с любым заданным фактически постоянным уровнем температуры $t_{1}$, согласно приводимым ниже нормам, установленным для трех классов:

Класс А. Вагон-рефрижератор, имеющий такую холодильную установку, при которой $t_{1}$ может выбираться в пределах между $+12^{\circ} \mathrm{C}$ и $0^{\circ} \mathrm{C}$ включительно.

Класс В. Вагон-рефрижератор, имеющий такую холодильную установку, при которой $t$ ! может выбираться в пределах между $+12^{\circ} \mathrm{C}$ и $-10^{\circ} \mathrm{C}$ включительно.

Класс С. Вагон-рефрижератор, имеющий такую холодильную установку, при которой t! может выбираться в пределах между $+12^{\circ} \mathrm{C} u-20^{\circ} \mathrm{C}$ включительно. 


\section{А.II-26. Отапливаемый вагон}

Изотермический вагон, имеющий отопительную установку.

Такой вагон позволяет повышать температуру внутри порожнего кузова и затем поддерживать ее в течение по меньшей мере 12 часов без дополнительной подачи тепла на практически постоянном уровне не менее $+12^{\circ} \mathrm{C}$ при средней наружной температуре кузова, которая указана ниже для двух классов:

Класс A. Отопительное оборудование, используемое в случаях, когда средняя наружная температура составляет $-10^{\circ} \mathrm{C} ; u$

Класс B. Отопительное оборудование, используемое в случаях, когда средняя наружная температура составляет $-20^{\circ} \mathrm{C}$.

\section{А.II-27. Полувагон}

Вагон без крыши с неоткидными бортами высотой более 60 см.

\section{А.II-28. Вагон-платформа}

Вагон без крыши и бортов, вагон без крыши с бортами высотой не более 60 см или опрокидывающаяся платформа обычного либо специального типа.

Вагоны, сконструированные исключительно для перевозки контейнеров, съемных кузовов или грузовых автотранспортных средств, в эту категорию не входят.

\section{А.II-29. Вагон-цистерна}

Вагон, сконструированный для перевозки больших объемов жидкости или газа.

\section{A.II-30. Бункерный вагон}

Вагоны для перевозки навалом сыпучих грузов, например цемента, муки, гипса и т.д.

\section{A.II-31. Вагон для интермодальных перевозок}

Вагон, специально построенный или оборудованный для перевозки интермодальных транспортных единиц (ИТЕ) или других грузовых автотранспортных средств (см. F.II-10).

\section{A.II-32. Грузоподъемность вагона}

Грузоподъемность вагона - разрешенный максимальный вес грузов, которые могут в нем перевозиться. 


\section{A.III. ПРЕДПРИЯТИЯ, ЭКОНОМИЧЕСКАЯ ДЕЯТЕЛЬНОСТЬ И СФЕРА ЗАНЯТОСТИ}

\section{A.III-01. Хозяйствующий субъект на железнодорожном транспорте}

Любой частный или государственный хозяйствующий субъект, функционирующий главным образом в качестве железнодорожного предприятия, в качестве управляющего инфраструктурой либо комплексной компании.

В эту категорию следует включать хозяйствующие субъекты, основной вид деятельности которых не связан с железными дорогами, если они имеют относительно большую долю на рынке железнодорожных перевозках. Следует регистрировать только виды деятельность, связанные с железными дорогами.

\section{A.III-02. Железнодорожное предприятие}

Любое государственное или частное предприятие, предоставляющее услуги по перевозке грузов и/или пассажиров по железной дороге.

В эту категорию включены все предприятия, располагающие тяговыми возможностями/предоставляющие такие возможности. Исключаются железнодорожные предприятия, функционирующче полностью или главным образом на промышленных и аналогичных объектах, в том числе в портах, $u$ железнодорожные предприятия, которые предоставляют главным образом местные туристические услуги, как, например, железные дороги, на которых эксплуатируются сохранившиеся классические паровозы.

Иногда используется термин "железнодорожный оператор".

\section{A.III-03. Управляющий инфраструктурой}

Любой государственный орган или предприятие, отвечающие, в частности, за создание и техническое обслуживание железнодорожной инфраструктуры, а также за функционирование систем контроля и безопасности.

Управляющий инфраструктурой может передавать другому хозяйствующему субъекту на железнодорожном транспорте следующие функиии: техническое обслуживание железнодорожной инфраструктуры, а также функционирование системы контроля и безопасности.

\section{A.III-04. Комплексная компания}

Железнодорожное предприятие, являющееся также управляющим инфраструктурой. 


\section{A.III-05. Сфера занятости}

Среднее число лиц, работающих в течение данного периода в хозяйствующем субъекте на железнодорожном транспорте, а также лиц, работающих за пределами этого хозяйствующего субъекта, но входящих в его штат и получающих заработную плату непосредственно от него.

Эти статистические данные должны включать всех сотрудников, занятых полную рабочую неделю на выполнении всех основных и вспомогательных видов деятельности хозяйствующего субъекта (железнодорожные операции, модернизация, новое строительство, дорожное и экспедиторское обслуживание, производство электроэнергии, гостиницы и рестораны и т.д.).

\section{А.III-06. Виды занятости}

К основным категориям занятости относятся:

\section{- Общая администрация}

Включает цеентральный и региональный управленческий персонал (например, по финансовым, правовым, кадровым и т.д. вопросам) и советы директоров.

Управленческий персонал специализированных отделов (транспортных операций и управления движением, службы тяги и подвижного состава, дорожноэксплуатационных и путевых работ) исключается, однако учитывается 8 статистических данных, касающихся каждой из этих служб.

- Транспортные операции и управление движением

Сотрудники станциионных служб (за исключением сотрудников, обеспечивающих функиионирование систем контроля и безопасности), поездные бригады (за исключением бригад тяговых единиц), а также персонал соответствующих центральныхх и региональных ведомств. Включаются сотрудники туристических и рекламных агентств.

- Службы тяги и подвижного состава

Бригады тяговых единии, персонал мастерских, инспекторы, а также персонал соответствующих иентральных и региональных ведомств.

- Дорожно-эксплуатационные и путевые работы

Постоянный персонал ремонтно-эксплуатационных служб и служб технического контроля (включая сотрудников, отвечающцих за функционирование систем контроля и безопасности). 
- $\quad$ Прочие операции

Пассажирские и грузовые автомобильные перевозки, экспедиторские услуги, выработка электроэнергии, услуги гостиничного персонала и т.д.

\section{A.III-07. Оборот}

Общий объем операций, осуществленных хозяйствующим субъектом на железнодорожном транспорте за рассматриваемый период. Это соответствует объему рыночных продаж товаров или услуг, предоставленных третьим сторонам. Оборот включает все налоги и пошлины на товары или услуги, произведенные компанией, без учета НДС, взимаемого предприятием с заказчиков. Он также включает все другие начисления, относимые на счет заказчиков. Из него должны вычитаться снижение цен, возврат части цены и скидки, а также стоимость возвращенной тары, но не скидки при сделках за наличные.

Оборот не включает продажи основного капитала. Исключаются также субсидии на осуществление транспортных операций, полученные от государственных органов.

\section{А.III-08. Поступления}

Суммы, которые выражаются в денежных единицах и которые поступают на доходную часть счетов хозяйствующего субъекта на железнодорожном транспорте.

\section{А.III-09. Типы поступлений}

К основным категориям поступлений относятся:

- Поступления от транспортных операций

В эту категорию включаются поступления от перевозки грузов и пассажсиов.

- Суммы, получаемые от государства или государственных органов

В эту категорию включаются компенсачионные выплаты и другие субсидии.

- Прочие поступления

В эту категорию включаются поступления, не связанные с транспортной деятельностью, например финансовые поступления и т.д.

\section{А.III-10. Расходы}

Суммы имеющихся источников, расходуемые хозяйствующим субъектом на железнодорожном транспорте в связи с транспортной операцией или операцией по 
предоставлению услуг или с рядом транспортных операций и операций по предоставлению услуг.

\section{A.III-11. Виды расходов}

К основным категориям расходов относятся:

- Издержки на рабочую силу

Включаются заработная плата рабочих и служащих, пенсии, различные отчисления на социальные цели и т.д.

- Издержки на материалы и стоимость услуг

Включаются закупка других материалов и оплата услуг, предоставляемых третьими сторонами, за вычетом расходов на энергию для тяговых единиц.

- $\quad$ Расходы на энергию

Включаются суммы, выделенные под количество энергии для тяговых единиц.

- $\quad$ Налоги

- $\quad$ Финансовые отчисления

- $\quad$ Прочие расходы

Включаются суммы амортизационных отчислений, резервные фонды и т.д.

\section{A.III-12. Добавленная стоимость}

Валовая продукция (сбыт или денежные поступления и другой доход плюс изменение стоимости товарно-материальных запасов) хозяйствующего субъекта на железнодорожном транспорте за вычетом расходов на его промежуточное потребление. Добавленная стоимость отечественного производства всех хозяйствующих субъектов на железнодорожном транспорте в какой-либо стране равняется их вкладу в ВВП этой страны.

Предполагается, что добавленная стоимость здесь указывается в рыночных цеенах.

\section{A.III-13. Капиталовложения в материальные активы}

Расходы (закупки и производство за собственный счет) хозяйствующего субъекта на железнодорожном транспорте на расширение своего основного капитала за счет новых и бывших в употреблении средств производства (товаров производственного 
назначения) за вычетом чистого дохода, полученного от продаж аналогичных подержанных и отбракованных товаров.

Вклад всех хозяйствуюших субъектов на железнодорожном транспорте в валовые вложения в основной капитал страны равняется общему объему их инвестиций в материальные активы за вычетом разницы в цене покупки и продажи земли.

\section{A.III-14. Капиталовложения в инфраструктуру}

Расходы на строительство новой и расширение существующей инфраструктуры, включая реконструкцию, обновление и капитальный ремонт объектов инфраструктуры.

Инфраструктура включает землю, постоянные путевые сооружения, здания, мосты и туннели, а такюе связанные с ними стационарные объекты, устройства и установки (сигнализация, телекоммуникации, контактная сеть, электрические подстанциии и т.д.) в отличие от подвижного состава.

\section{A.III-15. Капиталовложения в подвижной состав}

Расходы на приобретение новых железнодорожных транспортных средств.

\section{A.III-16. Расходы на содержание инфраструктуры}

Расходы на поддержание инфраструктуры в рабочем состоянии.

\section{A.III-17. Расходы на содержание подвижного состава}

Расходы на поддержание железнодорожных транспортных средств в рабочем состоянии.

\section{A.IV. ДВИЖЕНИЕ}

\section{A.IV-01. Железнодорожное движение}

Любое движение железнодорожного транспортного средства по эксплуатационным линиям.

Если какое-либо железнодорожное транспортное средство перевозится на другом транспортном средстве, то учитывается движение только перевозящего транспортного средства (активный вид транспорта).

\section{A.IV-02. Маневровая работа}

Операция по передвижению железнодорожного транспортного средства или группы железнодорожных транспортных средств в пределах железнодорожной станции или иных железнодорожных объектов (депо, мастерских, сортировочной станции и т.д.). 


\section{A.IV-03. Железнодорожное движение по национальной территории}

Любое движение железнодорожных транспортных средств в пределах национальной территории, независимо от страны, в которой эти транспортные средства зарегистрированы.

\section{A.IV-04. Рейс железнодорожного транспортного средства}

Любое передвижение железнодорожного транспортного средства из установленного пункта отправления в установленный пункт назначения.

Рейс может подразделяться на участки или этапьл.

\section{A.IV-05. Поезд}

Одно или несколько железнодорожных транспортных средств, буксируемых одним или несколькими локомотивами либо автомотрисами, или одиночная автомотриса, двигающаяся под определенным номером либо под отдельным обозначением между конкретным исходным пунктом и конкретным конечным пунктом.

Одиночный локомотив, т.е. локомотив, осуществляющий самостоятельное движение, в качестве поезда не рассматривается.

\section{A.IV-06. Типы поездов}

К основным категориям относятся:

- Грузовой поезд: предназначенный для перевозки грузов поезд, состоящий из одного или нескольких товарных вагонов и, в соответствующих случаях, из багажных вагонов, передвигающихся либо порожняком, либо загруженными.

- Пассажирский поезд: предназначенный для перевозки пассажиров поезд, состоящий из одного или нескольких пассажирских железнодорожных транспортных средств и, в соответствующих случаях, из багажных вагонов, передвигающихся либо порожняком, либо загруженными.

- Смешанный поезд: поезд, состоящий из пассажирских железнодорожных транспортных средств и товарных вагонов.

- $\quad$ Прочие поезда: поезда, осуществляющие движение только по требованию хозяйствующего субъекта на железнодорожном транспорте и не использующиеся для коммерческих перевозок. 


\section{A.IV-07. Поездо-километр}

Единица измерения, соответствующая передвижению поезда на расстояние в один километр.

Под расстоянием подразумевается фактически пройденное расстояние.

\section{A.IV-08. Тяговое транспортное средство-километр}

Единица измерения, соответствующая любому передвижению активного тягового транспортного средства на расстояние в один километр.

В эту категорию включаются одиночные тяговые транспортные средства. Исключаются транспортные средства, осуществляющие маневровые операции.

\section{A.IV-09. Буксируемое транспортное средство-километр}

Единица измерения, соответствующая любому передвижению буксируемого транспортного средства на расстояние в один километр.

Включается движение автомотрис. Исключаются маневровые операции.

\section{A.IV-10. Предлагаемый тонно-километр}

Единица измерения, соответствующая перевозке одной тонны в товарном вагоне на расстояние в один километр в процессе транспортировки, для которой этот вагон первоначально предназначался.

Следует учитывать расстояние фактического пробега. Исключаются маневровые и другие аналогичные операчии.

\section{A.IV-11. Вагоно-километр}

Единица измерения, соответствующая любому передвижению одного груженого или порожнего товарного вагона на расстояние в один километр.

Следует учитывать расстояние фактического пробега. Исключаются маневровые и другие аналогичные операчии. Учитываются все пробеги вагонов, независимо от того, кто является собственником вагона.

\section{A.IV-12. Предлагаемое место-километр}

Единица измерения, соответствующая перевозке одного места в пассажирском железнодорожном транспортном средстве на расстояние в один километр в процессе транспортировки, для которой это транспортное средство первоначально предназначалось. 
Следует учитывать расстояние фактического пробега. Исключаются маневровые и другие аналогичные операции.

\section{A.IV-13. Буксируемый тонно-километр брутто-брутто}

Единица измерения, соответствующая передвижению на расстояние в один километр одной тонны массы железнодорожного транспортного средства, включая массу тягового транспортного средства.

Включается общая масса тяговой единищь, буксируемого железнодорожного транспортного средства и его груза. Исключается масса пассажиров и их багажа. Исключаются маневровые и другие аналогичные операчии.

\section{A.IV-14. Буксируемый тонно-километр брутто}

Единица измерения, соответствующая передвижению на расстояние в один километр одной тонны массы буксируемых транспортных средств (и автомотрис) и их груза.

Включается масса автомотрис, но исключается масса локомотивов. Исключается масса пассажиров и их багажа. Исключаются маневровые и другие аналогичные операции.

\section{А.V. ИЗМЕРЕНИЕ ОБЪЕМА ПЕРЕВОЗОК}

\section{A.V-01. Железнодорожная перевозка}

Любая перевозка грузов и/или пассажиров на железнодорожном транспортном средстве по данной железнодорожной сети.

Если железнодорожное транспортное средство перевозится на другом железнодорожном транспортном средстве, то учитывается движение только перевозящего транспортного средства (активный вид транспорта).

\section{A.V-02. Виды железнодорожных перевозок}

К основным категориям относятся:

- $\quad$ коммерческие железнодорожные перевозки: перевозки, осуществляемые в интересах другой стороны за плату;

- $\quad$ служебные железнодорожные перевозки: перевозки, производимые хозяйствующим субъектом на железнодорожном транспорте для удовлетворения своих внутренних потребностей, независимо от того, приносят ли они доход, подлежащий бухгалтерскому учету. 


\section{A.V-03. Национальная железнодорожная перевозка}

Железнодорожная перевозка между двумя пунктами (пунктом погрузки/посадки и пунктом разгрузки/высадки), находящимися в одной и той же стране, независимо от страны, в которой были зарегистрированы железнодорожные транспортные средства.

Эта перевозка может включать транзитную перевозку через вторую страну.

\section{A.V-04. Международная железнодорожная перевозка}

Железнодорожная перевозка между двумя пунктами (пунктом погрузки/посадки и пунктом разгрузки/высадки) в двух разных странах.

Эта перевозка может включать транзитную перевозку через одну или несколько дополнительных стран.

\section{A.V-05. Транзитная железнодорожная перевозка}

Железнодорожная перевозка по стране между двумя пунктами (пунктом погрузки/посадки и пунктом разгрузки/высадки), находящимися за пределами этой страны.

Транзитной перевозкой не считаются транспортные операции, предусматривающие погрузку/посадку или разгрузку/высадку из железнодорожного транспортного средства на границе этой странь с другого вида транспорта/на другой вид транспорта.

\section{A.V-06. Пассажир железнодорожного транспорта}

Любое лицо, за исключением членов поездной бригады, совершающее поездку на железнодорожном транспорте.

Исключаются пассажиры, совершающие поездку только на паромах или автобусах, эксплуатируемьх железной дорогой.

\section{A.V-07. Коммерческий пассажир железнодорожного транспорта}

Пассажир, имеющий оплаченный билет.

\section{A.V-08. Пассажиро-километр на железнодорожном транспорте}

Единица измерения, соответствующая перевозке по железной дороге одного пассажира на расстояние в один километр. 
Следует учитывать расстояние, которое фактически проехал пассажир в данной сети. Если это расстояние неизвестно, то в этом случае следует учитывать расстояние, за которое фактически взимается плата, или оценочное расстояние.

\section{A.V-09. Цель поездки пассажира железнодорожного транспорта}

Мотивы поездки:

- работа и учеба (регулярные поездки),

- деловые поездки,

- $\quad$ поездки в праздничные дни (каникулы или отпуск),

- $\quad$ прочие поездки (в магазины, с целью отдыха, семейные поездки).

\section{A.V-10. Пассажир железнодорожного транспорта, совершивший посадку}

Пассажир, совершающий посадку в железнодорожное транспортное средство с целью поездки.

Прямая пересадка пассажира с одного железнодорожного транспортного средства на другое, независимо от железнодорожного предприятия, не рассматривается в качестве высадки/посадки.

Каждый случай использования в ходе пересадки другого вида транспорта рассматривается в качестве высадки из железнодорожного транспортного средства с последующей посадкой на железнодорожное транспортное средство.

\section{A.V-11. Пассажир железнодорожного транспорта, совершивший высадку}

Пассажир, высаживающийся из железнодорожного транспортного средства после поездки.

Прямая пересадка пассажира с одного железнодорожного транспортного средства на другое, независимо от железнодорожного предприятия, не рассматривается в качестве высадки/посадки.

Каждый случай использования в ходе пересадки другого вида транспорта рассматривается в качестве высадки из железнодорожного транспортного средства с последующей посадкой на железнодорожное транспортное средство.

\section{A.V-12. Поездка пассажира железнодорожного транспорта}

Сочетание пункта посадки и пункта высадки пассажиров, перевозимых железной дорогой, независимо от маршрута в железнодорожной сети. 


\section{A.V-13. Пункт посадки}

Пункт, в котором пассажир железнодорожного транспорта осуществляет посадку на железнодорожное транспортное средство с целью поездки.

Прямая пересадка пассажира с одного железнодорожного транспортного средства на другое, независимо от железнодорожного предприятия, не рассматривается в качестве высадки/посадки.

Каждый случай использования в ходе пересадки другого вида транспорта рассматривается в качестве высадки из железнодорожного транспортного средства с последующей посадкой на железнодорожное транспортное средство.

\section{A.V-14. Пункт высадки}

Пункт, в котором пассажир железнодорожного транспорта высаживается из железнодорожного транспортного средства после поездки.

Прямая пересадка пассажира с одного железнодорожного транспортного средства на другое, независимо от железнодорожного предприятия, не рассматривается в качестве высадки/посадки.

Каждый случай использования в ходе пересадки другого вида транспорта рассматривается в качестве высадки из железнодорожного транспортного средства с последующей посадкой на железнодорожное транспортное средство.

\section{A.V-15. Грузы, перевезенные железнодорожным транспортом}

Любые грузы, перевезенные на железнодорожных транспортных средствах.

К этим грузам относятся все грузовые места и оборудование, как, например, контейнеры, съемные кузова или поддоны, а также грузовые автотранспортные средства, перевезенные железнодорожным транспортом.

\section{A.V-16. Грузовая отправка}

Партия грузов, перевезенная по одному и тому же транспортному документу в соответствии с действующими правилами или тарифами, если таковые имеются.

\section{A.V-17. Виды грузовых отправок}

Основными категориями являются:

- маршрутная отправка: любая грузовая отправка, состоящая из одной или нескольких повагонных отправок, переданных одновременно для перевозки одним и тем же грузоотправителем на одной и той же станции и отправляемых 
без изменения состава поезда по адресу одного и того же грузополучателя на одну и ту же станцию назначения;

- $\quad$ повагонная отправка: любая грузовая отправка, для перевозки которой необходим весь вагон, независимо от того, полностью используется его грузоподъемность или нет;

- $\quad$ мелкие отправки: любая грузовая отправка, для перевозки которой не нужен и не требуется весь вагон.

\section{A.V-18. Macca}

Учитываемой массой является масса брутто-брутто груза.

В эту массу включается общзая масса грузов, всей упаковки и масса тары контейнера, съемного кузова и поддонов, содержащих грузы, а также масса автодорожных транспортных средств, перевозимых железнодорожным транспортом. Когда масса тары исключается, учитываемой массой является масса брутто.

\section{A.V-19. Тонно-километр на железнодорожном транспорте}

Единица измерения грузовых перевозок, соответствующая железнодорожной перевозке одной тонны грузов на расстояние в один километр.

Под расстоянием понимается фактически пройденное расстояние в рассматриваемой сети. Если это расстояние неизвестно, то в таком случае следует учитывать расстояние, за которое фактически взимается плата, или оченочное расстояние.

\section{A.V-20. Категории грузов, перевозимых железнодорожным транспортом}

К категориям грузов, перевозимых железнодорожным транспортом, относятся категории, определенные в используемой международной номенклатуре для транспортной статистики, утвержденной Евростатом, ЕКМТ или ЕЭК ООН.

\section{A.V-21. Опасные грузы}

Классы опасных грузов, перевозимых железнодорожным транспортом, определены в Правилах международной перевозки опасных грузов по железным дорогам (МПОГ).

\section{A.V-22. Погруженный груз}

Груз, помещенный на железнодорожное транспортное средство и перевозимый железнодорожным транспортом. 
В отличие от автомобильных и внутренних водных перевозок прямая перегрузка с одного железнодорожного транспортного средства на другое и смена тягового транспортного средства не рассматриваются в качестве разгрузки/погрузки. Однако если груз выгружается из железнодорожного транспортного средства, грузится на другой вид транспорта и вновь загружается на другое железнодорожное транспортное средство, то эта операџия рассматривается $в$ качестве выгрузки из первого железнодорожного транспортного средства и последующей погрузки на второе железнодорожное транспортное средство.

\section{A.V-23. Выгруженный груз}

Груз, снятый с железнодорожного транспортного средства после железнодорожной перевозки.

В отличие от автомобильных и внутренних водных перевозок прямая перегрузка с одного железнодорожного транспортного средства на другое и смена тягового транспортного средства не рассматриваются в качестве разгрузки/погрузки. Однако если груз выгружается из железнодорожного транспортного средства, грузится на другой вид транспорта и вновь загружается на другое железнодорожное транспортное средство, то эта операџия рассматривается 8 качестве выгрузки из первого железнодорожного транспортного средства и последующей погрузки на второе железнодорожное транспортное средство.

\section{A.V-24. Международные грузовые перевозки железнодорожным транспортом - погрузка (вывозимые грузы)}

Грузы, перевозимые железнодорожным транспортом между пунктом погрузки, находящимся в стране-респонденте, и пунктом разгрузки в другой стране.

Не включаются сквозные транзитные грузы. Включаются вагоны, загруженные на железнодорожной сети и перевозимые на паромах до иностранной сети.

\section{A.V-25. Международные грузовые перевозки железнодорожным транспортом - разгрузка (ввозимые грузы)}

Грузы, перевозимые на железнодорожном транспорте между пунктом погрузки, находящимся в иностранном государстве, и пунктом разгрузки в странереспонденте.

Не включаются сквозные транзитные грузы. Включаются вагоны, загруженные на иностранной железнодорожной сети и перевозимые на паромах до сети страны, представляющей отчетность. 


\section{A.V-26. Сквозные транзитные грузы, перевозимые железнодорожным транспортом}

Грузы, перевозимые железнодорожным транспортом по территории страныреспондента между двумя пунктами (пункт погрузки/разгрузки), находящимися за пределами этой страны.

Включаются вагоны, ввозимые в сеть, по которой представляется информация, и/или вывозимые из этой сети на паромах.

\section{A.V-27. Линия железнодорожного грузового сообщения}

Сочетание пункта погрузки и пункта выгрузки грузов, перевозимых железнодорожным транспортом, независимо от маршрута следования.

\section{A.V-28. Пункт погрузки}

Пункт, в котором грузы грузятся на железнодорожное транспортное средство с целью перевозки.

В отличие от автомобильных и внутренних водных перевозок прямая перегрузка с одного железнодорожного транспортного средства на другое и смена тягового транспортного средства не рассматриваются в качестве разгрузки/погрузки. Однако если груз выгружается из железнодорожного транспортного средства, грузится на другой вид транспорта и вновь загружается на другое железнодорожное транспортное средство, то эта операџия рассматривается в качестве выгрузки из первого железнодорожного транспортного средства и последующей погрузки на второе железнодорожное транспортное средство.

\section{А.V-29. Пункт разгрузки}

Пункт, в котором грузы выгружаются из железнодорожного транспортного средства после перевозки.

В отличие от автомобильных и внутренних водных перевозок прямая перегрузка с одного железнодорожного транспортного средства на другое и смена тягового транспортного средства не рассматриваются в качестве разгрузки/погрузки. Однако если груз выгружается из железнодорожного транспортного средства, грузится на другой вид транспорта и вновь загружается на другое железнодорожное транспортное средство, то эта операџия рассматривается в качестве выгрузки из первого железнодорожного транспортного средства и последующей погрузки на второе железнодорожное транспортное средство. 


\section{А.VI. ПОТРЕБЛЕНИЕ ЭНЕРГИИ}

\section{A.VI-01. Потребление энергии на железнодорожном транспорте}

Конечное потребление энергии тяговыми транспортными средствами с целью обеспечения тяги, а также службами движения и различными объектами (отопление, кондиционирование воздуха, освещение...).

\section{A.VI-02. Тонна нефтяного эквивалента (т н.э.)}

Единица измерения потребления энергии: 1 т н.э. = 0,041868 ТДж.

Переводные коэффициенты, принятые Международным энергетическим агентством (МЭА) на 1991 год:

$\begin{array}{ll}\text { - моторное топливо } & 1,070 \\ \text { - газойль/дизельное топливо } & 1,035 \\ \text { - тяжелое дизельное топливо } & 0,960 \\ \text { - сжиженный нефтяной газ } & 1,130 \\ \text { - природный газ } & 0,917\end{array}$

Переводной коэффиичент, используемый МЭА для электроэнергии, составляет: $1 \mathrm{TBm} . ч=0,086 \mathrm{Mm}$ н.э.

A.VI-03. Джоуль

Единица измерения потребления энергии:

1 тераджоуль $=10^{12}$ Дж $=2,78 \times 10^{5}$ кВт.ч

1 тераджоуль $=23,88459$ т н.э.

\section{A.VI-04. Моторное топливо (бензин)}

Легкое углеводородное топливо для использования в двигателях внутреннего сгорания, исключая топливо для самолетов.

Моторное топливо дистиллируется при температуре от $35^{\circ} \mathrm{C}$ до $215^{\circ} \mathrm{C} u$ подвергается реформингу, каталитическому крекингу или смешиванию с какой-либо ароматической фракиией для достижения достаточно высокого октанового числа ( $\geq 80$ ДОЧ).

Теплотворная способность: 44,8 ТДж/1 $000 \mathrm{~m}$.

\section{A.VI-05. Газойль/дизельное топливо (дистиллятное нефтетопливо)}

Топливо, полученное путем атмосферной перегонки самой низкой фракции сырой нефти. 
Газойль/дизельное топливо включает тяжелье газойли, получаемые путем вакуумной повторной перегонки остатков атмосферной перегонки.

Газойль/дизельное топливо дистиллируется при температуре $200^{\circ} \mathrm{C}-380^{\circ} \mathrm{C}$ менее чем на $65 \%$ по объему при $250^{\circ} \mathrm{C}$, включая потери, и на $80 \%$ или более при температуре $350^{\circ} \mathrm{C}$. Температура вспышки всегда выше $50^{\circ} \mathrm{C}$, а удельный вес более 0,81. Тяжелье фракиии, полученные путем смешивания, относятся к газойлю при условии, что их кинематическая вязкость не превышает $25 \mathrm{cCm}$ при $40^{\circ} \mathrm{C}$.

Теплотворная способность: 43,3 ТДж/1 $000 \mathrm{~m}$.

\section{A.VI-06. Тяжелое (остаточное) дизельное топливо}

Тяжелые виды топлива, состоящие из остатков перегонки.

Это топливо включает все остаточные дизельные топлива (в том числе те, которые получены путем смешивания). Вязкость тяжелого топлива превышает 25 сСт при $40^{\circ} \mathrm{C}$. Температура вспышки всегда выше $50^{\circ} \mathrm{C}$, а удельный вес - более 0,90 .

\section{A.VI-07. Сжиженные нефтяные газы (СНГ)}

Легкие фракции углеводородов парафинового ряда, полученные путем перегонки сырой нефти.

СНГ включают пропан и бутан или смесь этих двух углеводородов. Они могут быть сжижены при низком давлении (5-10 атмосфер). В жидком состоянии и при температуре $38^{\circ} \mathrm{C}$ показатель сравнительного давления пара составляет не более 24,5 бара. Их удельный вес может изменяться в пределах от 0,50 до 0,58.

\section{A.VI-08. Каменный уголь}

Природные окаменелые органические отложения черного цвета с высшей теплотворной способностью более 23860 кДж/кг (5 700 ккал/кг) в беззольных условиях при содержании влаги, достигаемой при температуре $30^{\circ} \mathrm{C}$, и при относительной влажности воздуха 96\%, со средним коэффициентом отражения витринита не менее 0,6 .

\section{A.VI-09. Бурый уголь - лигнит}

Уголь с низкой степенью коксования и высшей теплотворной способностью менее 23860 кДж/кг (5 700 ккал/кг) в условиях отсутствия сырой золы и содержания более $31 \%$ летучего вещества на основе, свободной от сухих минералов. 


\section{A.VI-10. Электрическая энергия}

Энергия, произведенная на гидроэлектрических, геотермальных, ядерных и обычных тепловых электростанциях, за исключением энергии, произведенной на гидроаккумулирующих станциях, и определенная на основе показателя теплотворной способности электроэнергии (3,6 ТДж/ГВт.ч).

Гидроаккумулирующая станщия представляет собой станцию, имеющую емкость, которая заполняется с помощью насосов.

\section{В. АВТОМОБИЛЬНЫЙ ТРАНСПОРТ}

\section{B.I. ИНФРАСТРУКТУРА}

\section{B.I-01. Дорога}

Линия сообщения (проезжий путь), имеющая твердое покрытие, за исключением железных дорог и взлетно-посадочных полос, открытая для общего пользования и предназначенная в основном для дорожных механических транспортных средств, передвигающихся на своих собственных колесах.

Включаются мосты, туннели, несущие конструкции, пересечения дорог, перекрестки и развязки. Включаются также платные дороги. Исключаются специальные велосипедные дорожки.

\section{B.I-02. Дорожная сеть}

Все дороги в данном районе.

\section{B.I-03. Категория дороги}

Классификация дорожной сети определяется а) администрацией, несущей ответственность за ее строительство, текущее содержание и/или эксплуатацию; b) в соответствии с конструкционными нормами или с) в зависимости от пользователей, имеющих право доступа на дорогу.

\section{В.I-04. Автомагистраль}

Дорога, которая специально построена и предназначена для движения автотранспортных средств, которая не обслуживает придорожных владений и которая:

a) за исключением отдельных мест или вре́менных ограничений, имеет для обоих направлений движения отдельные проезжие части, отделенные друг от друга разделительной полосой, не предназначенной для движения или, в исключительных случаях, другими средствами; 
b) не имеет пересечения на одном уровне ни с дорогами, ни с железнодорожными или трамвайными путями, ни с пешеходными дорожками;

c) специально обозначена в качестве автомагистрали и предназначена для использования конкретных категорий дорожных механических транспортных средств.

Полосы для въезда и выезда с автомагистрали включаются независимо от места нахождения дорожного знака. Включаются также городские автомагистрали.

\section{B.I-05. Городская дорога}

Дорога в пределах населенного пункта, въезды и выезды из которого обозначены с помощью специальных знаков.

\section{B.I-06. Дорога категории E}

Международная сеть дорог категории "Е" состоит из системы дорог, указанных в Европейском соглашении о международных автомагистралях, Женева, 15 ноября 1975 года, и в поправках к нему.

\section{B.I-07. Проезжая часть}

Часть дороги, предназначенная для движения дорожных механических транспортных средств; части дороги, которые образуют обочину с более низким или более высоким слоем дорожного покрытия, не являются проезжей частью; то же относится и к частям дороги, предназначенным для движения несамоходных дорожных транспортных средств или для стоянки транспортных средств, даже если в случае опасности эти дороги могут иногда использоваться для проезда механических транспортных средств. Ширина проезжей части измеряется перпендикулярно оси дороги.

\section{B.I-08. Полоса движения}

Одна из продольных полос, на которые подразделяется проезжая часть, независимо от наличия продольной дорожной разметки, и которая является достаточно широкой для движения в одну линию механических транспортных средств, за исключением мотоциклов.

\section{B.I-09. Трамвайный путь}

Линия сообщения, представляющая собой пару рельсов и предназначенная для движения трамваев. 
Она включает трамвайный путь, проложенный по дороге, используемой другими дорожными механическими транспортными средствами, а также трамвайный путь, проходящий отдельно от дороги.

\section{В.II. ТРАНСПОРТНОЕ ОБОРУДОВАНИЕ (ТРАНСПОРТНЫЕ СРЕДСТВА)}

\section{B.II-01. Дорожное транспортное средство}

Транспортное средство на колесах, предназначенное для использования на дорогах.

\section{B.II-02. Парк дорожных транспортных средств}

Количество дорожных транспортных средств, которые зарегистрированы на дунную дату в стране и которые можно использовать на дорогах, открытых для общего пользования.

Он включает дорожные транспортные средства, освобожденные от уплатьл ежегодных налогов или сборов; он также включает ввезенные подержанные транспортные средства и другие дорожные транспортные средства в соответствии с национальной практикой. Из этих статистических данных следует исключать военные транспортные средства.

\section{B.II-03. Национальное дорожное транспортное средство}

Дорожное транспортное средства, зарегистрированное в стране-респонденте, имеющее номерные знаки этой страны или зарегистрованное отдельно (трамваи, троллейбусы и т.д.).

Если в какой-либо конкретной стране регистрация дорожных транспортных средств отсутствует, то национальным дорожным транспортным средством является транспортное средство, которым владеет или которое сдает внаем компания, находящаяся в этой стране и уплачивающая налоги.

\section{B.II-04. Иностранное дорожное транспортное средство}

Дорожное транспортное средство, зарегистрированное в стране иной, чем странареспондент, и имеющее номерные знаки этой страны.

\section{В.II-05. Дорожное механическое транспортное средство}

Дорожное транспортное средство, оборудованное двигателем, который является единственным средством для приведения его в движение, и обычно используемое для перевозки пассажиров или грузов или для буксировки на дорогах транспортных средств, используемых для перевозки пассажиров или грузов.

Из этих статистических данных исключаются механические транспортные средства, передвигающиеся по рельсам. 


\section{B.II-06. Пассажирское дорожное транспортное средство}

Дорожное транспортное средство, предназначенное исключительно или преимущественно для перевозки одного или нескольких человек.

Транспортные средства, предназначенные для перевозки как пассажиров, так и грузов, следует относить либо к пассажирским дорожным транспортным средствам, либо к грузовым дорожным транспортным средствам в зависимости от их основного назначения, что определяется их техническими характеристиками или категорией для иелей налогообложения.

\section{В.II-07. Велосипед}

Дорожное транспортное средство, которое имеет два или более колес и приводится в движение исключительно мускульной энергией лиц, находящихся в этом транспортном средстве, в частности с помощью системы педалей, рычага или рукоятки (например, двухколесный, трехколесный, четырехколесный велосипеды, а также инвалидные коляски).

\section{B.II-08. Пассажирское дорожное механическое транспортное средство}

Дорожное механическое транспортное средство, предназначенное исключительно или преимущественно для перевозки одного или более человек.

Транспортное средство, предназначенное для перевозки как пассажиров, так и грузов, следует относить либо к пассажирским дорожным транспортным средствам, либо к грузовым дорожным транспортным средствам в зависимости от их основного назначения, что определяется их техническими характеристиками или их категорией для ичелей налогообложения.

\section{B.II-09. Типы пассажирских дорожных механических транспортных средств}

Эти транспортные средства могут классифицироваться в соответствии с видом энергии, которая используется в двигателе; основные виды энергии:

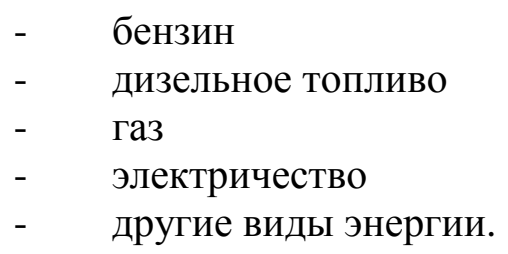

\section{В.II-10. Мопед}

Двух- или трехколесное дорожное транспортное средство, которое оборудовано двигателем с рабочим объемом цилиндров менее $50 \mathrm{~cm}^{3}\left(3,05\right.$ дюйма $\left.{ }^{3}\right)$ и 
максимально разрешенная конструктивная скорость которого соответствует национальным правилам.

\section{B.II-11. Мотоцикл}

Двухколесное дорожное механическое транспортное средство с прицепной коляской или без нее, включая мотороллер или трехколесное дорожное механическое транспортное средство, порожний вес которого не превышает 400 кг (900 фунтов). Включаются все такие транспортные средства с рабочим объемом цилиндров $50 \mathrm{~cm}^{3}$ или более, а также транспортные средства, рабочий объем цилиндров которых составляет менее $50 \mathrm{~cm}^{3}$ и которые не подпадают под определение мопеда.

\section{B.II-12. Пассажирский автомобиль}

Дорожное механическое транспортно средство, иное, чем мотоцикл, предназначенное для перевозки пассажиров и имеющее не более девяти сидячих мест (включая место водителя).

Иными словами, термин "пассажирский автомобиль" охватывает микроавтомобили (для вождения которых не требуется водительских удостоверений), такси и взятые напрокат пассажирские автомобили при условии, что они имеют менее десяти сидячих мест. В эту категорию могут также входить пикапь.

\section{B.II-13. Жилой прицеп}

Дорожное транспортное средство, не предназначенное для перевозки пассажиров и/или грузов и предназначенное для буксировки пассажирским автомобилем.

Иными словами, термин "жилой прицеп" включает дорожное транспортное средство, предназначенное в основном для целей отдыха.

\section{B.II-14. Автобус дальнего следования или городской автобус}

Пассажирское дорожное механическое транспортное средство, предназначенное для перевозки пассажиров и имеющее более девяти сидячих мест (включая место водителя).

В эти статистические данные также включаются мини-автобусы для перевозки пассажиров, имеющие более девяти сидячих мест (включая место водителя).

\section{В.II-15. Троллейбус}

Пассажирское дорожное транспортное средство, которое предназначено для перевозки пассажиров, имеет более девяти сидячих мест (включая место водителя), соединено с электрическими проводами и не передвигается по рельсам. 
Этот термин охватывает транспортные средства, которые иногда используются в качестве троллейбусов, а иногда - в качестве автобусов (поскольку они имеют отдельный двигатель).

\section{B.II-16. Трамвай}

Пассажирское дорожное транспортное средство, которое предназначено для перевозки пассажиров, имеет более девяти сидячих мест (включая место водителя), соединено с электрическими проводами или приводится в движение с помощью дизельного двигателя и передвигается по рельсам.

\section{B.II-17. Число сидячих/спальных мест в автобусах дальнего следования, городских автобусах и троллейбусах}

Число сидячих/спальных мест, включая место водителя, имеющихся в транспортном средстве при использовании его в целях, для которых оно преимущественно предназначено.

В случае сомнения следует учитывать наибольщее число имеющихся сидячих/спальных мест.

\section{B.II-18. Грузовое дорожное транспортное средство}

Дорожное транспортное средство, предназначенное исключительно или преимущественно для перевозки грузов.

Транспортные средства, предназначенные для перевозки как пассажиров, так и грузов, следует относить либо к пассажирским дорожным транспортным средствам, либо к грузовым дорожным транспортным средствам в зависимости от их основного назначения, что определяется их техническими характеристиками или их категорией для иелей налогообложения.

\section{B.II-19. Типы кузова грузовых дорожных транспортных средств}

Классификация грузовых дорожных транспортных средств по типам их верхней части конструкции. Используется следующая классификация типов кузовов грузовых дорожных транспортных средств:

- обычный открытый кузов (1)

- с крышей

- $\quad$ плоский

- $\quad$ самосвал (2)

- цистерна (3)

- твердые навалочные грузы

- жидкие наливные грузы

- $\quad$ кузов с регулируемой температурой (4) 
- $\quad$ другие закрытые кузова (5)

- $\quad$ кузов для перевозки решетчатого контейнера и съемного кузова (6)

- $\quad$ кузов для перевозки скота (7)

- $\quad$ другие кузова (8)

\section{B.II-20. Грузовое дорожное механическое транспортное средство}

Любое одиночное дорожное механическое транспортное средство, предназначенное для перевозки грузов (грузовой автомобиль), или любое другое сочлененное дорожное транспортное средство, предназначенное для перевозки грузов (например, грузовой автомобиль с прицепом (прицепами) или дорожное транспортное средствотягач с полуприцепом и прицепом или без прицепа).

\section{B.II-21. Грузовой автомобиль}

Дорожное механическое транспортное средство на жесткой раме, предназначенное исключительно или преимущественно для перевозки грузов.

В эту категорию включаются фургоны, которые представляют собой дорожные механические транспортные средства на жесткой раме, которые предназначены исключительно или преимущественно для перевозки грузов и масса-брутто которых составляет менее 3500 кг. В эту категорию могут также включаться пикапь.

\section{B.II-22. Дорожный тягач}

Дорожное механическое транспортное средство, предназначенное исключительно или преимущественно для буксировки других дорожных транспортных средств, которые не имеют механического привода (в основном полуприцепы).

Исключаются сельскохозяйственные тракторы.

\section{B.II-23. Сельскохозяйственный трактор}

Механическое транспортное средство, предназначенное исключительно или преимущественно для сельскохозяйственных целей, независимо от того, разрешается ему или нет использовать дороги, открытые для общего пользования.

\section{B.II-24. Прицеп}

Грузовое дорожное транспортное средство, предназначенное для буксировки дорожным механическим транспортным средством.

Из этой категории исключаются сельскохозяйственные прицепы и жилье прищепы. 


\section{В.II-25. Сельскохозяйственный прицеп}

Прицеп, предназначенный исключительно и преимущественно для сельскохозяйственных целей и для буксировки сельскохозяйственным трактором, независимо от того, разрешается ему или нет использовать дороги, открытые для общего пользования.

\section{В.II-26. Полуприцеп}

Грузовое дорожное транспортное средство без передней оси, сконструированное таким образом, чтобы часть этого транспортного средства и значительная часть веса находящегося на нем груза опирались на дорожный тягач.

\section{В.II-27. Сочлененное транспортное средство}

Дорожный тягач, сцепленный с полуприцепом.

\section{B.II-28. Автопоезд}

Грузовое дорожное механическое транспортное средство, сцепленное с прицепом.

В эту категорию включается сочлененное транспортное средство с дополнительньм прицепом.

\section{B.II-29. Транспортное средство специального назначения}

Дорожное транспортное средство, предназначенное для целей иных, чем перевозка пассажиров или грузов.

В эту категорию включаются, например, пожарные автомобили, автомобили скорой помощи, автокраны, самодвижущиеся катки, бульдозеры с металлическими колесами или на гусеничном ходу, транспортные средства для съемки фильмов, радио- и телевизионных программ, транспортные средства для передвижных библиотек, тягачи для транспортных средств, нуждающихся в ремонте, и другие не указанные конкретно дорожные транспортные средства.

\section{B.II-30. Грузоподъемность}

Максимальная масса грузов, объявленная допустимой компетентным органом страны регистрации транспортного средства.

\section{В.II-31. Полная масса транспортного средства (разрешенная максимальная масса)}

Общая масса неподвижного транспортного средства, готового к движению (или состава транспортных средств), включая находящийся на нем груз, объявленная допустимой компетентным органом страны регистрации. 
Этот показатель включает массу водителя и всех других одновременно перевозимых лиц.

\section{B.II-32. Возраст дорожного транспортного средства}

Период времени после первой регистрации дорожного транспортного средства независимо от страны регистрации.

\section{B.II-33. Рабочий объем цилиндров}

Рабочий объем цилиндров, удостоверенный компетентным органом страны регистрации.

\section{B.II-34. Масса порожнего транспортного средства}

Масса порожнего транспортного средства, удостоверенная компетентным органом страны регистрации.

\section{В.II-35. Вид энергии, на котором работает двигатель}

Основной вид энергии, на котором работает двигатель транспортного средства, удостоверенный компетентным органом страны регистрации.

Для гибридных или двухтопливных транспортных средств, которые оборудованы для работы на более чем одном виде топлива (например, на СНГ и бензине или на электроэнергии и дизельном топливе и т.д.), основным видом энергии, на котором работает двигатель, должно быть по возможности альтернативное топливо.

\section{В.II-36. Альтернативное топливо}

Вид энергии, на котором работает двигатель, кроме обычных видов топлива (бензина и дизельного топлива).

Альтернативные виды топлива включают электроэнергию, СНГ, природный газ (сжиженный или сжатый), спирты, смеси спиртов с другими видами топлива, водород, биотопливо (например, биодизельное топливо) и т.д. (неисчерпьвающий перечень). Альтернативные виды топлива не включают неэтилированный бензин, реформированный бензин или городское дизельное топливо (с низким содержанием серьl).

\section{В.III. ПРЕДПРИЯТИЯ, ЭКОНОМИЧЕСКАЯ ДЕЯТЕЛЬНОСТЬ И СФЕРА ЗАНЯТОСТИ}

\section{B.III-01. Перевозка по найму или за вознаграждение}

Перевозка пассажиров или грузов за плату, производимая за счет третьих лиц. 


\section{B.III-02. Перевозка за собственный счет}

Перевозка, которая осуществляется не по найму и не за вознаграждение.

\section{В.III-03. Предприятие}

Институциональная единица или наименьшее объединение институциональных единиц, которые охватывают и прямо или косвенно контролируют все функции, необходимые для осуществления производственной деятельности ${ }^{1}$.

Требования, предъявляемые к предприятию, состоят в том, что на предприятие распространяется единый режим собственности или контроля. Однако оно может быть гетерогенным в отношении своей экономической деятельности и своего местоположения.

\section{B.III-04. Автотранспортное предприятие}

Предприятие, которое осуществляет в одном или более местах деятельность по производству автотранспортных услуг с использованием дорожных транспортных средств и основными видами деятельности которого в связи с производством добавленной стоимости являются автомобильные перевозки.

В отраслевых классификащиях видов деятельности используется следующее подразделение:

- МСОК/ред.3ㄹ: подраздел 60, группа 602 - Прочий сухопутный транспорт; подгруппа 6021 - Прочий пассажирский сухопутный транспорт, подчиняюшийся расписанию; подгруппа 6022 - Прочий пассажирский сухопутный транспорт, не подчиняюшийся расписанию; подгруппа 6023 - Фрахтовые перевозки автодорожным транспортом;

\footnotetext{
1 МСОК/Третий пересмотренный вариант - Международная стандартная отраслевая классификация всех видов экономической деятельности, Статистические документы, серия М, № 4, ред. 3, Организация Объединенных Наций, 1990 год.

2 МСОК/Третий пересмотренный вариант - Международная стандартная отраслевая классификация всех видов экономической деятельности. Статистические документы, серия М, № 4, ред. 3, Организация Объединенных Наций, 1990 год.
} 
- КДЕС/ред.1 ${ }^{3}$ : подраздел 60, группа 602 - Городской и автомобильный транспорт;

подгруппа 60.21 - Пассажирский транспорт, подчиняющийся расписанию; подгруппа 60.22 - Перевозки на такси;

подгруппа 60.23 - Прочий автомобильный пассажсирский транспорт; подгруппа 60.24 - Автомобильный грузовой транспорт.

Учитываются даже те предприятия, которые не имеют наемных служащих. Следует учитывать только те единицы, которые фактически осуществляют деятельность в течение рассматриваемого периода. Исключаются "спящие" единицы или те единицы, которые не приступили к своей деятельности.

\section{B.III-05. Предприятие пассажирского автотранспорта}

Автотранспортное предприятие, которое предлагает и оказывает услуги по перевозке одного или более человек (пассажиров), исключая водителя, и основными видами деятельности которого в области автомобильных перевозок в связи с производством добавленной стоимости являются автомобильные пассажирские перевозки.

\section{B.III-06. Предприятие грузового автотранспорта}

Автотранспортное предприятие, которое предлагает и оказывает услуги по перевозке грузов и основными видами деятельности которого в области автомобильных перевозок в связи с производством добавленной стоимости являются автомобильные грузовые перевозки.

\section{B.III-07. Предприятие городского пассажирского автотранспорта}

Автотранспортное предприятие, которое осуществляет пассажирские городские, пригородные или подобные перевозки по расписанию или не по расписанию в пределах границ одного или более населенных пунктов и основными видами деятельности которого в области пассажирских автомобильных перевозок в связи с производством добавленной стоимости являются городские пассажирские автомобильные перевозки.

\section{B.III-08. Государственное автотранспортное предприятие}

Автотранспортное предприятие, которое в основном принадлежит (боле 50\% капитала) государству или государственным органам власти и их предприятиям.

3 КДЕС/ред. 1 - Статистическая классификация видов экономической деятельности Европейского сообщества, Официальный бюллетень, № L 83, 3 апреля 1990 года. 


\section{B.III-09. Сфера занятости}

Среднее число лиц, работающих в течение данного периода на автотранспортном предприятии (включая работающих собственников, партнеров, работающих регулярно на предприятии и не оплачиваемых работников, занятых на семейном предприятии), а также лиц, работающих за пределами этого предприятия, однако входящих в его штат и получающих заработную плату непосредственно от этого предприятия.

\section{B.III-10. Оборот}

Общий объем операций, осуществленный автотранспортным предприятием за рассматриваемый период. Это соответствует объему рыночных продаж товаров или услуг, предоставленных третьим сторонам. Оборот включает все налоги и пошлины на товары или услуги, произведенные предприятием, без учета НДС, взимаемого предприятием с заказчиков. Он также включает все другие начисления, относимые на счет заказчиков. Из него должны вычитаться снижение цен, возврат части цены и скидки, а также стоимость возвращенной тары, но не скидки при сделках за наличные.

Оборот не включает продажи основного капитала. Исключаются также эксплуатационные субсидии, полученные от государственных органов.

\section{B.III-11. Поступления}

Суммы, которые выражаются в денежных единицах и которые поступают на доходную часть счета автотранспортного предприятия.

\section{B.III-12. Типы поступлений}

К основным категориям поступлений относятся:

- Поступления от транспортных операций

В эту категорию включаются поступления от перевозки грузов и пассажиров.

- Суммы, получаемые от государства или государственных органов

В эту категорию включаются компенсаџионные выплаты и другие субсидии.

- $\quad$ Прочие поступления

В эту категорию включаются поступления, не связанные с транспортной деятельностью, например, финансовые поступления и т.д. 


\section{B.III-13. Расходы}

Суммы имеющихся источников, расходуемые автотранспортным предприятием в связи с транспортной операцией или операцией по предоставлению услуг либо с рядом транспортных операций и операций по предоставлению услуг.

\section{В.III-14. Виды расходов}

К основным категориям расходов относятся:

- Издержки на рабочую силу

Включается заработная плата рабочих и служащих, пенсии, различные отчисления на сочиальные ичели и т.д.

- Издержки на материалы и стоимость услуг

Включается закупка других материалов и оплата услуг, предоставляемьх третьими сторонами, за вычетом расходов на энергию.

- Расходы на энергию

- $\quad$ Налоги

- Финансовые отчисления

- $\quad$ Прочие расходы

Включаются суммы амортизационных отчислений, резервные фонды и т.д.

\section{B.III-15. Добавленная стоимость}

Валовая продукция автотранспортного предприятия за вычетом издержек на его промежуточное потребление. Добавленная стоимость отечественного производства всех автотранспортных предприятий в какой-либо стране равняется их вкладу в ВВП этой страны.

Предполагается, что добавленная стоимость здесь указывается в рыночных иченах.

\section{В.III-16. Капиталовложения в материальные активы}

Расходы (закупки и производство за собственный счет) автотранспортных предприятий на расширение своего основного капитала за счет новых и бывших в употреблении средств производства (товаров производственного назначения) за вычетом чистого дохода, полученного от продаж аналогичных подержанных и отбракованных товаров. 
Вклад всех автотранспортных предприятий в валовые вложения в основной капитал страны равняется общему объему их капиталовложений в материальные активы за вычетом разницы в цене покупки и продажи земли.

\section{B.III-17. Капиталовложения в дороги}

Расходы на строительство новых дорог и расширение инфраструктуры существующих дорог, включая реконструкцию, обновление и капитальный ремонт.

\section{B.III-18. Капиталовложения в дорожные транспортные средства}

Расходы на приобретение дорожных транспортных средств.

\section{B.III-19. Расходы на содержание дорог}

Расходы на поддержание дорог в рабочем состоянии.

Эти расходы включают содержание дорожного покрытия, ремонт отдельных участков и текущий ремонт (работы по устранению неровностей на проезжей части, вызванных износом, ремонт обочины и т.д.).

\section{B.III-20. Расходы на содержание дорожных транспортных средств}

Расходы на поддержание дорожных транспортных средств в рабочем состоянии.

\section{B.IV. ДВИЖЕНИЕ}

\section{B.IV-01. Дорожное движение}

Любое движение дорожного транспортного средства по данной сети.

Если дорожное транспортное средство перевозится на другом транспортном средстве, то учитывается движение только перевозящего транспортного средства (активньй вид транспорта).

\section{B.IV-02. Дорожное движение по национальной территории}

Любое движение дорожных транспортных средств в пределах национальной территории, независимо от страны, в которой это транспортное средство зарегистрировано.

\section{B.IV-03. Дорожное движение порожних транспортных средств}

Любое движение дорожного транспортного средства, для которого масса бруттобрутто перевозимых грузов, включая массу оборудования, такого, как контейнеры, съемные кузова и поддоны, равняется нулю; а также любое движение автобусов 
дальнего следования, городских автобусов, троллейбусов и трамваев без пассажиров.

Движение дорожного транспортного средства, перевозящего порожнее оборудование, такое, как контейнеры, съемные кузова и поддоны, не рассматривается в качестве порожнего пробега.

\section{B.IV-04. Городское дорожное движение}

Движение, осуществляемое по городским дорогам или трамвайным путям.

Участки транзитного рейса, включающие сравнительно непродолжсительный пробег по городским дорогам, не учитываются в качестве городского дорожного движения.

\section{B.IV-05. Рейс дорожного транспортного средства}

Передвижение дорожного транспортного средства из пункта отправления в пункте назначения.

Рейс может подразделяться на ряд участков или этапов.

\section{B.IV-06. Транспортное средство-километр}

Единица измерения, соответствующая передвижению дорожного механического транспортного средства на расстояние в один километр.

Следует учитывать расстояние фактического пробега. Включается передвижение порожних дорожных механических транспортных средств. Транспортные единицы, состоящие из тягача и полуприцепа или из грузового автомобиля и прицепа, учитываются в качестве одного транспортного средства.

\section{B.IV-07. Предлагаемый тонно-километр}

Единица изренения, соответствующая перевозке одной тонны в дорожном грузовом транспортном средстве на расстояние в один километр при осуществлении перевозок, для которых оно первоначально предназначалось.

Следует учитывать расстояние фактического пробега.

\section{B.IV-08. Предлагаемое место-километр для сидящего/стоящего пассажира}

Единица измерения, соответствующая перевозке одного сидящего/стоящего пассажира в дорожном транспортном средстве на расстояние в один километр, при осуществлении перевозок, для которых оно первоначально предназначалось.

Следует учитывать расстояние фактического пробега. 


\section{B.IV-09. Прибывшее дорожное транспортное средство}

Любое груженое или порожнее дорожное механическое транспортное средство, которое прибыло в страну по автомобильной дороге.

Если дорожное механическое транспортное средство прибывает в страну на другом виде транспорта, то считается, что в страну прибыл только активный вид транспорта.

\section{B.IV-10. Выбывшее дорожное транспортное средство}

Любое груженое или порожнее дорожное механическое транспортное средство, которое выбыло из страны по автомобильной дороге.

Если дорожное механическое транспортное средство выбывает из страны на другом виде транспорта, то считается, что из страны выбывает только активньй вид транспорта.

\section{B.IV-11. Дорожное транспортное средство, следующее транзитом}

Любое груженое или порожнее дорожное механическое транспортное средство, которое прибывает в страну или выбывает из нее через разные пункты, независимо от вида транспорта, при условии, что вся перевозка в пределах этой страны осуществляется по автомобильным дорогам и что в ней не производится ни погрузка, ни выгрузка.

Включаются дорожные механические транспортные средства, которые на границе этой станы грузятся на другой вид транспорта или выгружаются с него.

\section{В.V. ИЗМЕРЕНИЕ ОБЪЕМА ПЕРЕВОЗОК}

\section{B.V-01. Автодорожная перевозка}

Любая перевозка грузов и/или пассажиров на дорожном транспортном средстве по данной дорожной сети.

Если дорожное транспортное средство перевозится на другом транспортном средстве, то учитывается движение только перевозящего транспортного средства (активный вид транспорта).

\section{B.V-02. Национальная автодорожная перевозка}

Автодорожная перевозка между двумя пунктами (пунктом погрузки/посадки и пунктом разгрузки/высадки), находящимися в одной и той же стране, независимо от 
страны, в которой зарегистрировано транспортное средство. Эта перевозка может включать транзитную перевозку через вторую страну.

\section{B.V-03. Каботажная автодорожная перевозка}

Национальная автодорожная перевозка, осуществляемая на механическом транспортном средстве, зарегистрированном в другой стране.

\section{B.V-04. Международная автодорожная перевозка}

Автодорожная перевозка между двумя пунктами (пунктом погрузки/посадки и пунктом разгрузки/высадки) в двух разных странах. Эта перевозка может включать транзитную перевозку через одну или более дополнительных стран.

\section{B.V-05. Автодорожная перевозка, осуществляемая третьей стороной}

Международная автодорожная перевозка, осуществляемая на дорожном механическом транспортном средстве, зарегистрированном в третьей стране.

Третьей страной является страна, в которой не производится погрузка/посадка, или страна, в которой не производится разгрузка/высадка.

\section{B.V-06. Автодорожная транзитная перевозка}

Автодорожная перевозка по стране между двумя пунктами (пунктом погрузки и пунктом разгрузки), причем оба пункта находятся в другой стране или в других странах, при условии, что вся перевозка в пределах данной страны осуществляется по автомобильной дороге и что в этой стране не производится ни погрузка, ни разгрузка.

Включаются дорожные механические транспортные средства, которые на границе данной страны грузятся на другой вид транспорта или выгружаются с него.

\section{B.V-07. Городская автодорожная перевозка}

Перевозка, осуществляемая по городским дорогам или трамвайным путям.

В качестве городской перевозки учитываются только те перевозки, которые осуществляются в основном или только по городским дорогам.

\section{В.V-08. Пассажир автомобильного транспорта}

Любое лицо, совершающее поездку на дорожном транспортном средстве. Водители пассажирских автомобилей, исключая водителей такси, учитываются в качестве пассажиров. Обслуживающий персонал, предназначенный для городских автобусов, автобусов дальнего следования, троллейбусов, трамваев и грузовых дорожных транспортных средств, не учитывается в качестве пассажиров. 


\section{B.V-09. Пассажиро-километр на автомобильном транспорте}

Единица измерения, соответствующая перевозке одного пассажира по автомобильной дороге на расстояние в один километр.

Следует учитывать расстояние, которое фактически проехал пассажир.

\section{B.V-10. Цель поездки пассажира автомобильного транспорта}

Мотивы поездки:

- работа и учеба (регулярные поездки)

- деловые поездки

- $\quad$ поездки в праздничные дни (каникулы или отпуск)

- прочие поездки (в магазины, с целью отдыха, семейные поездки).

\section{B.V-11. Пассажир автомобильного транспорта, совершивший посадку}

Пассажир, совершающий посадку в дорожное транспортное средство с целью поездки.

Пересадка с одного дорожного транспортного средства на другое рассматривается в качестве посадки после высадки.

\section{B.V-12. Пассажир автомобильного транспорта, совершивший высадку}

Пассажир, высаживающийся из дорожного транспортного средства после поездки.

Пересадка с одного дорожного транспортного средства на другое рассматривается в качестве высадки перед повторной посадкой.

\section{B.V-13. Линия автомобильного пассажирского сообщения}

Сочетание пункта посадки и пункта высадки пассажиров, перевозимых автомобильным транспортом, независимо от маршрута следования.

Эти пункты определяются с помощью международных классификационных систем, таких, как НТЕС (номенклатура территориальньх единии для статистики - Евростат).

\section{В.V-14. Пункт посадки}

В качестве такого пункта рассматривается пункт, в котором пассажир совершает посадку на дорожное транспортное средство с целью поездки. 
Пересадка из одного дорожного транспортного средства на другое рассматривается в качестве посадки после высадки.

\section{B.V-15. Пункт высадки}

В качестве такого пункта рассматривается пункт, в котором пассажир совершает высадку из дорожного транспортного средства после поездки.

Пересадка с одного дорожного транспортного средства на другое рассматривается в качестве высадки перед повторной посадкой.

\section{B.V-16. Грузы, перевозимые автомобильным транспортом}

Любые грузы, перевезенные на грузовых дорожных транспортных средствах.

К этим грузам относятся все грузовые места и оборудование, такое, как контейнеры, съемные кузова или поддоны.

\section{B.V-17. Macca}

Учитываемой массой является масса брутто - брутто-груза.

В эту массу включается общая масса груза, всей упаковки и масса тары контейнера, съемного кузова и поддонов, содержащих грузы. Когда масса тары исключается, то учитываемой массой является масса брутто.

\section{B.V-18. Тонно-километр на автомобильном транспорте}

Единица измерения грузовых перевозок, соответствующая автомобильной перевозке одной тонны груза на расстояние в один километр.

Следует учитывать расстояние фактического пробега.

\section{B.V-19. Типы грузов, перевозимых автомобильным транспортом}

К категориям грузов, перевозимых автомобильным транспортом, относятся категории, определенные в номенклатуре НСТ/Р (Стандартная грузовая номенклатура для транспортной статистики/пересмотренный вариант - Евростат) или в номенклатуре КЕТС (Классификация грузов для европейской транспортной статистики ЕЭК ООН).

\section{B.V-20. Опасные грузы}

Классы опасных грузов, перевозимых автомобильным транспортом, определены в Европейском соглашении о международной дорожной перевозке опасных грузов (ДОПОГ). 


\section{B.V-21. Погруженный груз}

Груз, помещенный на дорожное транспортное средство и перевозимый автомобильным транспортом.

Перегрузка с одного грузового дорожного транспортного средства на другое или смена дорожного тягача рассматривается в качестве погрузки после выгрузки.

\section{B.V-22. Выгруженный груз}

Груз, снятый с дорожного транспортного средства после автомобильной перевозки.

Перегрузка с одного грузового дорожного транспортного средства на другое или смена дорожного тягача рассматривается в качестве выгрузки перед повторной погрузкой.

\section{B.V-23. Грузы, вывозимые из страны автомобильным транспортом (в отличие от} сквозных транзитных грузов, перевозимых автомобильным транспортом)

Грузы, погруженные на дорожное транспортное средство в данной стране, вывезенные из страны автомобильным транспортом и выгруженные в другой стране.

\section{B.V-24. Грузы, ввозимые в страну автомобильным транспортом (в отличие от сквозных транзитных грузов, перевозимых автомобильным транспортом)}

Грузы, погруженные на дорожное транспортное средство в другой стране, ввезенные в страну автомобильным транспортом и разгруженные в этой стране.

\section{B.V-25. Сквозные транзитные грузы, перевозимые автомобильным транспортом}

Грузы, ввезенные в страну по автомобильной дороге и вывезенные из страны по автомобильной дороге через пункт, иной, чем пункт ввоза, после их перевозки через территорию страны на одном и том же дорожном механическом транспортном средстве.

Перегрузка с одного грузового дорожного транспортного средства на другое или смена дорожного тягача рассматривается в качестве погрузки/разгрузки.

\section{B.V-26. Линия автомобильного грузового сообщения}

Сочетание пункта погрузки и пункта выгрузки грузов, перевозимых автомобильным транспортом, независимо от маршрута следования.

Эти пункты определяются с помощью международных классификащионных систем, таких, как НТЕС (Номенклатура территориальных единиц для статистики - Евростат). 


\section{В.V-27. Пункт погрузки}

В качестве такого пункта рассматривается пункт, в котором грузы грузятся на грузовое дорожное механическое транспортное средство или в котором производится смена дорожного тягача.

\section{B.V-28. Пункт разгрузки}

В качестве такого пункта рассматривается пункт, в котором грузы выгружаются с грузового дорожного механического транспортного средства или в котором производится смена дорожного тягача.

\section{В.VI. ПОТРЕБЛЕНИЕ ЭНЕРГИИ}

\section{B.VI-01. Потребление энергии на автомобильном транспорте}

Конечное потребление энергии дорожными механическими транспортными средствами.

\section{B.VI-02. Тонна нефтяного эквивалента (т н.э.)}

Единица измерения потребления энергии (1 т н.э = ТДж).

Переводные коэффициенты, принятые Международным энергетическим агентством (МЭА) на 1991 год:

$\begin{array}{lll}\text { - } & \text { моторное топливо } & 1,070 \\ \text { - } & \text { газойль/дизельное топливо } & 1,035 \\ \text { - } & \text { тяжелое дизельное топливо } & 0,960 \\ \text { - } & \text { сжиженный нефтяной газ } & 1,130 \\ \text { - } & \text { природньй газ } & 0,917\end{array}$

Переводной коэффициент, используемый МЭА для электроэнергии, составляет: 1 TBm.ч = 0,86 Mm н.э.

\section{B.VI-03. Джоуль}

Единица измерения потребления энергии:

1 тераджоуль $=10^{12}$ Дж $=2,78 \times 10^{5}$ кВт.ч

1 тераджоуль $=23,88459$ т н.э.

\section{B.VI-04. Моторное топливо (бензин)}

Легкое углеводородное топливо для использования в двигателях внутреннего сгорания, исключая топливо для самолетов. 
Моторное топливо дистиллируется при температуре от $35^{\circ} \mathrm{C}$ до $215^{\circ} \mathrm{C}$ и подвергается реформингу, каталитическому крекингу или смешиванию с какой-либо ароматической фракцией для достижения достаточно высокого октанового числа $\geq 80$ ДОЧ).

Теплотворная способность: 44,8 ТДж/1 000 т.

\section{B.VI -05. Газойль/дизельное топливо (дистиллятное нефтетопливо)}

Топливо, полученное путем атмосферной перегонки самой низкой фракции сырой нефти.

Газойль/дизельное топливо включает тяжелье газойли, получаемые путем вакуумной повторной перегонки остатков атмосферной перегонки.

Газойль/дизельное топливо дистиллируется при температуре $200^{\circ} \mathrm{C}-380^{\circ} \mathrm{C}$ менее чем на $65 \%$ по объему при $250^{\circ} \mathrm{C}$, включая потери, и на $80 \%$ или более при температуре $350^{\circ} \mathrm{C}$. Температура вспышки всегда выше $50^{\circ} \mathrm{C}$, а удельньй вес более 0,81. Тяжелые фракиии, полученные путем смешивания, относятся к газойлю при условии, что их кинематическая вязкость не превышает $25 \mathrm{cCm}$ при $40^{\circ} \mathrm{C}$.

Теплотворная способность: 43,3 ТДж/1 000 т.

\section{B.VI-06. Сжиженные нефтяные газы (СНГ)}

Легкие фракции углеводородов парафинового ряда, полученные путем перегонки сырой нефти.

СНГ включает пропан и бутан или смесь этих двух углеводородов. Они могут быть сжижены при низком давлении (5-10 атмосфер). В жидком состоянии и при температуре $38^{\circ} \mathrm{C}$ показатель сравнительного давления пара меньше или равен 24,5 бара. Их удельный вес может изменяться в пределах от 0,50 до 0,58.

\section{B.VI-07. Сжиженный природный газ (СПГ)}

Жидкие или сжиженные углеводороды, получаемые при производстве, очистке и стабилизации природного газа. Их характеристики изменяются в пределах от характеристик этана, бутана и пропана до характеристик тяжелых масел. СПГ либо подвергается перегонке из сырой нефти на нефтеперегонных заводах с добавлением очищенных нефтепродуктов, либо используется непосредственно в зависимости от его характеристик.

\section{B.VI-08. Электрическая энергия}

Энергия, произведенная на гидроэлектрических, геотермальных, ядерных и обычных тепловых электростанциях, за исключением энергии, произведенной на 
гидроаккумулирующих станциях, и определенная на основе показателя теплотворной способности электроэнергии (3,6 ТДж/ГВт.ч).

Гидроаккумулирующая станщия представляет собой станцию, имеющую емкость, которая заполняется с помощью насосов.

\section{В.VII. ДОРОЖНО-ТРАНСПОРТНЫЕ ПРОИСШЕСТВИЯ}

\section{B.VII-01. Дорожно-транспортное происшествие с нанесением травмы}

Любое дорожно-транспортное происшествие с участием по крайней мере одного дорожного транспортного средства, движущегося по дороге общего пользования или частной дороге, открытой для общего пользования, в результате которого ранен или погиб по крайней мере один человек.

Включаются столкновения между дорожными транспортными средствами; между дорожными транспортными средствами и пешеходами; между дорожными транспортными средствами и животными или неподвижными препятствиями и столкновения с участием только одного дорожного транспортного средства. Включаются столкновения между автодорожными и железнодорожными транспортными средствами. Столкновения с участием нескольких транспортных средств учитываются как одно дорожно-транспортное происшествие при условии, что последовательные столкновения происходят с весьма короткими интервалами. Из дорожно-транспортных происшествий с нанесением травмы исключаются дорожно-транспортные происшествия с нанесением только материального ущерба.

\section{B.VII-02. Дорожно-транспортное происшествие со смертельным исходом}

Любое дорожно-транспортное происшествие с нанесением травмы, в результате которого погиб человек.

\section{B.VII-03. Дорожно-транспортное происшествие без смертельного исхода}

Любое дорожно-транспортное происшествие с нанесением травмы, кроме дорожнотранспортного происшествия со смертельным исходом.

\section{B.VII-04. Потерпевший}

Любой погибший или раненый в результате дорожно-транспортного происшествия с нанесением травмы.

\section{B.VII-05. Погибший}

Любой погибший на месте или скончавшийся в течение 30 дней в результате дорожно-транспортного происшествия с нанесением травмы. 
Для стран, не применяющих данное определение, коэффищиент преобразования устанавливается с таким расчетом, чтобы обеспечить возможность сопоставления на основе определения, предусматривающего 30-дневный срок.

Францฺия 1.057 Италия 1.03 Латвия 1.08 Португалия 1.3 Туричия 1.3

\section{B.VII-06. Раненый}

Любой человек, не погибший, но получивший ранение в результате дорожнотранспортного происшествия с нанесением травмы и нуждающийся в обычном медицинском лечении.

\section{B.VII-07. Тяжелораненый}

Любой раненый, который был госпитализирован на период свыше 24 часов.

\section{B.VII-08. Легкораненый}

Любой раненый, за исключением тяжелораненого.

\section{B.VII-09. Водитель (причастный к дорожно-транспортному происшествию с нанесением травмы)}

Любой участник дорожно-транспортного происшествия с нанесением травмы, управлявший дорожным транспортным средством на момент дорожнотранспортного происшествия.

\section{B.VII-10. Пассажир (причастный к дорожно-транспортному происшествию с нанесением травмы)}

Любой участник дорожно-транспортного происшествия с нанесением травмы, кроме водителя, находившийся внутри дорожного транспортного средства или на нем или садившийся внутрь дорожно-транспортного средства или высаживавшийся из него.

\section{B.VII-11. Пешеход (причастный к дорожно-транспортному происшествию с нанесением травмы)}

Любой участник дорожно-транспортного происшествия с нанесением травмы; кроме пассажира или водителя, определенных выше.

Включаются лища, находящиеся в детской или инвалидной коляске или любом другом небольшом средстве передвижения без двигателя, или лица, толкающие или тянущие вышеуказанные транспортные средства. Также включаются лица, толкающие велосипед, мопед, передвигающиеся на роликовых коньках, роликовой доске, на льюжах или при помощчи аналогичных средств. 


\section{B.VII-12. Дорожно-транспортное происшествие с участием дорожного транспортного средства и пешехода}

Любое дорожно-транспортное происшествие с нанесением травмы, участниками которого являются одно или несколько дорожных транспортных средств и один или несколько пешеходов.

Включаются дорожно-транспортные происшествия независимо от того, оказался ли пешеход участником дорожно-транспортного происшествия на его первом или последующем этапе, и независимо от того, был ли пешеход ранен или погиб на дороге или вне проезжей части.

\section{B.VII-13. Дорожно-транспортное происшествие с участием одного дорожного транспортного средства}

Любое дорожно-транспортное происшествие с нанесением травмы, в котором участвует только дорожное транспортное средство.

Включаются дорожно-транспортные происшествия с участием транспортных средств, пытающихся избежать столкновения и сворачивающих с проезжей части, или дорожно-транспортные происшествия, вызванные столкновением с препятствием или жсивотными на дороге. Исключаются столкновения с пешеходами и транспортными средствами, находящимися на стоянке.

\section{B.VII-14. Дорожно-транспортное происшествие с участием нескольких дорожных транспортных средств}

Любое дорожно-транспортное происшествие с нанесением травмы; участниками которого являются два дорожных транспортных средства или более.

Выделяются следующие типы дорожно-транспортных происшествий с нанесением травмы, участниками которых являются два дорожных транспортных средства или более:

a) Заднее столкновение: столкновение с другим транспортным средством, следующим по той же полосе проезжей части и движущимся в том же направлении, которое снизило скорость или временно остановилось.

Включаются столкновения с движущимися транспортными средствами; исключаются столкновения с транспортными средствами, находящимися на стоянке.

b) Лобовое столкновение: столкновение с другим транспортным средством, следующим по той же полосе проезжей части и движущимся в противоположном направлении, которое ввиду условий дорожного движения снизило скорость или временно остановилось. 
Включаются столкновения с транспортными средствами, которые снижают скорость или временно остановились; исключаются столкновения с транспортными средствами, находящимися на стоянке.

с) Столкновение, вызванное пересечением дороги или поворотом: столкновение с другим транспортным средством, движущимся под углом к траектории движения первого транспортного средства, вызванное пересечением дороги, выездом с дороги или въездом на дорогу.

Исключаются столкновения с остановившимися для поворота транспортными средствами, которые следует классифицировать как а) или $b$ ).

d) Прочие столкновения, включая столкновение с транспортными средствами, находящимися на стоянке: столкновение, происходящее при движении транспортных средств бок о бок, при обгоне или смене рядов; или столкновение с транспортным средством, которое находилось на стоянке или остановилось на краю проезжей части, на обочине, на специально обозначенных стояночных местах, на тротуаре или площадках для стоянки и т.д.

Включаются все столкновения, не охваченные пунктами а), b) и с). Составным элементом классификачии дорожно-транспортных происшествий с участием транспортных средств является момент первого столкновения на проезжей части или момент первого механического воздействия на транспортное средство.

B.VII-15. Дорожно-транспортное происшествие с участием водителей, которые, согласно протоколу, находились в состоянии алкогольного опьянения, под воздействием наркотиков или медикаментов

Любое дорожно-транспортное происшествие с нанесением травмы, при котором по крайней мере один водитель, согласно протоколу, находился в состоянии алкогольного опьянения, под воздействием наркотиков или медикаментов, в соответствии с национальными правилами.

\section{В.VII-16. В пределах населенных пунктов}

Пункт, въезд в который и выезд из которого обозначены соответствующими дорожными знаками. 


\section{B.VII-17. За пределами населенных пунктов}

Любые участки, кроме пунктов, въезды в которые и выезды из которых обозначены соответствующими дорожными знаками.

Включает автомагистрали, если не указано иное.

\section{B.VII-18. Светлое время суток}

В соответствии с протоколом полиции или других компетентных органов.

\section{B.VII-19. Темное время суток}

В соответствии с протоколом полиции или других компетентных органов.

\section{B.VII-20. Сумерки (или условия не известны)}

Остаточная категория, охватывающая случаи, когда условия естественного освещения являются очень плохими или не имеется никакой информации о состоянии освещенности.

\section{B.VII-21. Сухая дорожная поверхность}

Поверхность дороги, на которой нет воды, снега, льда или прочих веществ.

\section{B.VII-22. Прочая дорожная поверхность}

Любая другая дорожная поверхность, кроме сухой дорожной поверхности.

\section{С. ВНУТРЕННИЙ ВОДНЫЙ ТРАНСПОРТ (ВВТ)}

\section{С.I. ИНФРАСТРУКТУРА}

\section{C.I-01. Водный путь}

Река, канал, озеро или другое водное пространство, которое в силу природных или искусственных характеристик пригодно для судоходства.

Включаются водные пути морского характера (водные пути, обозначенные страной, представляющей информачию, в качестве пригодных для судоходства прежде всего морских судов). В водные пути также включаются устья рек; их границей является ближайшая к морю точка, в которой ширина реки одновременно составляет менее 3 км при низкой воде и менее 5 км при высокой воде. 


\section{C.I-02. Судоходный внутренний водный путь}

Водное пространство, не являющееся частью моря, по которому могут осуществлять движение нормально груженые суда грузоподъемностью не менее 50 тонн. Этот термин применяется как в отношении судоходных рек и озер, так и в отношении судоходных каналов.

Длина рек и каналов измеряется по осевой линии фарватера. Длина озер и заливов измеряется по кратчайшему судоходному пути между двумя наиболее удаленными точками, в которые и из которых осуществляются транспортные операции. Водный путь, образующий общую гранииу между двумя странами, включается 8 статистические данные обеими странами.

\section{C.I-03. Категории судоходных внутренних водных путей}

Категории судоходных внутренних водных путей определяются с учетом международных классификационных систем, например, с помощью систем, разработанных Европейской экономической комиссией Организации Объединенных Наций или Европейской конференцией министров транспорта.

\section{C.I-04. Судоходная река}

Природный водный путь, открытый для судоходства, независимо от того, улучшался он для целей судоходства или нет.

\section{C.I-05. Судоходное озеро}

Природное водное пространство, открытое для судоходства.

Включаются заливы (водное пространство с содержанием солоноватой воды, отделенное от моря береговой полосой).

\section{C.I-06. Судоходный канал}

Водный путь, построенный в основном для судоходства.

\section{C.I-07. Сеть судоходных внутренних водных путей}

Все судоходные внутренние водные пути, открытые для судоходства общего пользования в данном районе.

\section{C.I-08. Судоходный внутренний водный путь, регулярно используемый для перевозок}

Водные пути, по которым ежегодно производится определенный объем перевозок; этот объем, выраженный в тонно-километрах на километр водного пути, 
определяется соответствующим компетентным органом с учетом условий на сети водных путей этой страны.

\section{C.II. ТРАНСПОРТНОЕ ОБОРУДОВАНИЕ (СУДНО)}

\section{C.II-01. Судно ВВT}

Находящиеся на плаву суда, предназначенные для перевозки грузов или пассажирских перевозок общего пользования по судоходным внутренним водным путям.

Включаются суда, находящиеся в ремонте. Включаются суда, которые пригодны для внутреннего судоходства, но которые допущены к морским перевозкам (суда смешанного плавания река-море). Из этой категории исключаются: портовые плавучие средства, морские портовые лихтеры и морские портовые буксиры, паромы, рыболовецкие суда, землечерпальные снаряды, суда, осуществляющие гидротехнические работь, и суда, используемье исключительно под складские помещения, плавучие мастерские, плавучие дачи и прогулочные суда.

\section{C.II-02. Национальное судно ВВТ}

Судно ВВТ, которое зарегистрировано на данную дату в стране-респонденте.

Если в какой-либо конкретной стране регистращия судов для перевозок по внутренним водным путям отсутствует, то национальным судном ВВТ является судно, которым владеет компания, находящаяся в этой стране и уплачивающая налоги.

\section{С.II-03. Иностранное судно ВВТ}

Судно ВВТ, которое зарегистрировано на данную дату в стране иной, чем страна-респондент.

\section{C.II-04. Грузовое судно ВВТ}

Судно грузоподъемностью не менее 20 тонн, предназначенное для грузовых перевозок по судоходным внутренним водным путям.

\section{C.II-05. Пассажирское судно ВВТ}

Судно, предназначенное исключительно или в основном для пассажирских перевозок общего пользования по судоходным внутренним водным путям.

\section{C.II-06. Флот судов внутреннего плавания}

Количество судов ВВТ, зарегистрированных на данную дату в стране и допущенных к эксплуатации на внутренних водных путях, открытых для общего пользования. 
Изменения во флоте связаны с полным или частичным изменением типа судна или изменением флота судов внутреннего плавания страны-респондента в результате строительства новых судов, изменения их типа или грузоподъемности, закупки или продажи за гранищей, списания на слом, повреждения судов, включения в морской регистр или исключения из него.

\section{C.II-07. Самоходная баржа}

Грузовое судно ВВТ, имеющее собственную двигательную установку.

Буксируемые баржи, толкаемые баржи и толкаемые-буксируемые баржи, которые имеют только вспомогательный двигатель, в соответствующих случаях должны рассматриваться в качестве буксируемых барж, толкаемых барж или толкаемых-буксируемых барж. Тот факт, что самоходная баржа может быть использована для буксировки, не меняет ее назначения.

\section{C.II-08. Самоходная наливная баржа}

Самоходная баржа, предназначенная для перевозки наливом жидкостей и газов.

Наливные суда для массовой перевозки сыпучих грузов, таких, как иемент, мука, гипс и т.д., должны исключаться и учитываться вместе с самоходными баржами.

\section{C.II-09. Самоходная баржа-толкач}

Самоходная баржа, предназначенная или оборудованная для толкания толкаемых или толкаемых-буксируемых барж.

\section{C.II-10. Самоходная наливная баржа-толкач}

Самоходная баржа-толкач для перевозки наливом жидкостей или газов.

Наливные суда для массовой перевозки сыпучих грузов, таких, как иемент, мука, гипс и т.д., должны исключаться и учитываться вместе с самоходными баржами-толкачами.

\section{C.II-11. Самоходное судно типа "река-море"}

Грузовое судно ВВТ грузоподъемностью не менее 20 тонн, предназначенное также для перевозки грузов по морю и оборудованное собственной двигательной установкой мощностью не менее 37 кВт. 


\section{C.II-12. Несамоходная баржа}

Грузовое судно ВВТ, предназначенное для буксировки и не имеющее самостоятельной установки.

Наличие на несамоходной барже вспомогательного двигателя не меняет ее назначения.

\section{C.II-13. Несамоходная наливная баржа}

Несамоходная баржа для перевозки наливом жидкостей или газов.

Наливные суда для массовой перевозки сыпучих грузов, таких, как иемент, мука, гипс и т.д., должны исключаться и учитываться вместе с несамоходными баржами.

\section{C.II-14. Толкаемая баржа}

Грузовое судно ВВТ, предназначенное для толкания и не имеющее самостоятельной двигательной установки.

Наличие на толкаемой барже вспомогательного двигателя не меняет ее назначения.

\section{C.II-15. Толкаемая наливная баржа}

Толкаемая баржа для перевозки наливом жидкостей или газов.

Наливные суда для массовой перевозки сыпучих грузов, таких, как иемент, мука, гипс и т.д., должны исключаться и учитываться вместе с толкаемыми баржами.

\section{C.II-16. Толкаемая-буксируемая баржа}

Грузовое судно ВВТ, предназначенное для толкания или буксировки и не имеющее самостоятельной двигательной установки.

Наличие на толкаемой-буксируемой барже вспомогательного двигателя не меняет ее назначения.

\section{C.II-17. Толкаемая-буксируемая наливная баржа}

Толкаемая-буксируемая баржа для перевозки наливом жидкостей или газов.

Наливные суда для массовой перевозки сыпучих грузов, таких, как иемент, мука, гипс и т.д., должны исключаться и учитываться вместе с толкаемымибуксируемыми баржами. 


\section{C.II-18. Буксир}

Судно с источником двигательной силы мощностью не менее 37 кВт, предназначенное для буксировки несамоходных барж, толкаемых-буксируемых барж и плотов, но не для перевозки грузов.

Исключаются портовые и морские буксиры.

\section{C.II-19. Толкач}

Судно с источником двигательной силы мощностью не менее 37 кВт, предназначенное или приспособленное для толкания толкаемых или толкаемыхбуксируемых барж, но не для перевозки грузов.

Исключаются портовые буксиры.

\section{C.II-20. Толкач-буксир}

Судно с источником двигательной силы мощностью не менее 37 кВт, предназначенное или приспособленное для буксировки несамоходных барж, толкаемых-буксируемых барж или плотов или для толкания толкаемых и толкаемыхбуксируемых барж, но не для перевозки грузов.

\section{C.II-21. Грузоподъемность}

Максимальный выраженный в тоннах разрешенный вес грузов, которые судно может перевозить согласно судовым документам.

\section{C.II-22. Пассажировместимость пассажирского судна ВВТ}

Максимальное допустимое число пассажиров, которое судно может перевозить согласно судовым документам.

\section{C.II-23. Мощность (кВт)}

Механическая мощность, развиваемая двигателем, которым оборудовано судно.

Эта мощность измеряется в фактических киловаттах (мощность, передаваемая на гребной винт):

$1 \kappa B m=1,36$ л.с.; 1 л.с. $=0,735 \kappa$ Вm.

\section{C.II-24. Год постройки судна}

Год первоначальной постройки корпуса. 


\section{С.III. ПРЕДПРИЯТИЯ, ЭКОНОМИЧЕСКАЯ ДЕЯТЕЛЬНОСТЬ И СФЕРА ЗАНЯТОСТИ}

\section{C.III-01. Перевозка по найму или за вознаграждение}

Перевозка за плату пассажиров или грузов, производимая за счет третьих лиц.

\section{C.III-02. Перевозка за собственный счет}

Перевозка, которая осуществляется не по найму и не за вознаграждение.

\section{C.III-03. Предприятие}

Институциональная единица или наименьшее объединение институциональных единиц, которые охватывают и прямо или косвенно контролируют все функции, необходимые для осуществления своей производственной деятельности 4 .

Требования, предъявляемье к предприятию, состоят в том, что на предприятие распространяется единый режим собственности или контроля. Однако оно может быть гетерогенным в отночении своей экономической деятельности и своего местоположения.

\section{C.III-04. Предприятие ВВТ}

Предприятие, которое осуществляет в одном или более местах деятельность по производству услуг по внутренним водным перевозкам с использованием судов ВВТ и основными видами деятельности которого в связи с производством добавленной стоимости являются внутренние водные перевозки.

В отраслевых классификащиях видов деятельности используется следующее подразделение:

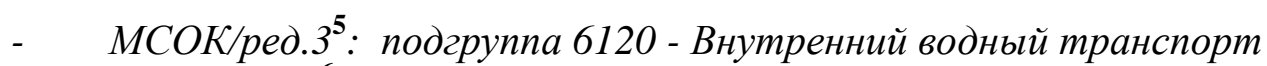

- $\quad$ КДЕС/ред.1 $1^{\mathbf{6}}$ : подгруппа 61.20 - Речной транспорт.

4 МСОК/Третий пересмотренный вариант - Международная стандартная отраслевая классификация всех видов экономической деятельности, Статистические документы, серия М, № 4, ред.3, Организация Объединенных Наций, 1990 год.

5 МСОК/Третий пересмотренный вариант - Международная стандартная отраслевая классификация всех видов экономической деятельности, Статистические документы, серия М, № 4, ред.3, Организация Объединенных Наций, 1990 год.

6 КДЕС/ред.1 - Статистическая классификация видов экономической деятельности Европейского союза, Официальный бюллетень, № 4 L 83, 3 апреля 1993 года. 
Учитываются даже те предприятия, которые не имеют наемных служащих. Следует учитывать только те единицы, которые фактически осуществляют деятельность в течение рассматриваемого периода. Исключаются "спящие" единицы или те единицы, которые не приступили к своей деятельности.

\section{C.III-05. Государственное предприятие ВBT}

Предприятие ВВТ, которое в основном принадлежит (более 50\% капитала) государству или государственным органам власти и их предприятиям.

\section{C.III-06. Сфера занятости}

Среднее число лиц, работающих в течение данного периода на предприятии BВТ (включая работающих собственников, партнеров, работающих регулярно на предприятии, и не оплачиваемых работников, занятых на семейном предприятии), а также лиц, работающих за пределами этого предприятия, однако входящих в его штат и получающих заработную плату непосредственно от этого предприятия.

\section{C.III-07. Оборот}

Общий объем операций, осуществленный предприятием BВТ за рассматриваемый период. Это соответствует объему рыночных продаж товаров и услуг, предоставленных третьим сторонам. Оборот включает все налоги и пошлины на товары или услуги, произведенные предприятием, без учета НДС, взимаемого предприятием с заказчиков. Он также включает все другие начисления, относимые на счет заказчиков. Из него должны вычитаться снижение цен, возврат части цены и скидки, а также стоимость возвращенной тары, но не скидки при сделках за наличные.

Оборот не включает продажи основного капитала. Исключаются также эксплуатационные субсидии, полученные от государственных органов.

\section{C.III-08. Поступления}

Суммы, которые выражаются в денежных единицах и которые поступают на доходную часть счета предприятия ВВТ.

\section{C.III-09. Типы поступлений}

К основным категориям поступлений относятся:

- Поступления от транспортных операций

В эту категорию включаются поступления от перевозки грузов и пассажиров.

- Суммы, получаемые от государства или от государственных органов 
В эту категорию включаются компенсационные выплаты и другие субсидии.

- Прочие поступления

В эту категорию включаются поступления, не связанные с транспортной деятельностью, например финансовые поступления и т.д.

\section{C.III-10. Расходы}

Суммы имеющихся источников, расходуемые предприятием ВВТ в связи с транспортной операцией или операцией по предоставлению услуг либо с рядом транспортных операций и операций по предоставлению услуг.

\section{C.III-11. Виды расходов}

К основным категориям расходов относятся:

- Издержки на рабочую силу

Включается заработная плата рабочих и служащих, пенсии, различные отчисления на социиальные цели и т.д.

- Издержки на материалы и стоимость услуг

Включается закупка других материалов и оплата услуг, предоставляемых третьими сторонами, за вычетом расходов на энергию.

- Расходы на энергию

- $\quad$ Налоги

- $\quad$ Финансовые отчисления

- Прочие расходы.

Включаются суммы амортизационных отчислений, резервные фонды и т.д.

\section{C.III-12. Добавленная стоимость}

Валовая продукция предприятия ВВТ за вычетом издержек на его промежуточное потребление. Добавленная стоимость отечественного производства всех предприятий ВВТ в какой-либо стране равняется их вкладу в ВВП этой страны.

Предполагается, что добавленная стоимость здесь указывается в рыночных ценах. 


\section{C.III-13. Капиталовложения в материальные активы}

Расходы (закупки и производство за собственный счет) предприятий ВВТ на расширение своего основного капитала за счет новых и бывших в употреблении средств производства (товары производственного назначения) за вычетом чистого дохода, полученного от продаж аналогичных подержанных и отбракованных товаров.

Вклад всех предприятий ВВТ в валовые вложения в основной капитал страны равняется общему объему их капиталовложений в материальные активы за вычетом разницы в цеене покупки и продажи земли.

\section{C.III-14. Капиталовложения в инфраструктуру}

Расходы на строительство новой и расширение существующей инфраструктуры, включая реконструкцию, обновление и капитальный ремонт.

Включаются расходы на шлюзыл.

\section{C.III-15. Капиталовложения в суда}

Расходы на приобретение судов.

\section{C.III-16. Расходы на содержание инфраструктуры}

Расходы на поддержание инфраструктуры в рабочем состоянии.

Включаются расходы на шлюзы.

\section{C.III-17. Рсходы на содержание судов}

Расходы на поддержание судов в рабочем состоянии.

\section{C.IV. ДВИЖЕНИЕ}

\section{C.IV-01. Движение по внутренним водным путям}

Любое движение судна ВВТ по данной сети.

Если судно перевозится на другом транспортном средстве, учитывается движение только перевозящегго транспортного средства (активный вид транспорта).

\section{C.IV-02. Движение по внутренним водным путям на национальной территории}

Любое движение судна ВВТ в пределах национальной территории независимо от страны, в которой это судно зарегистрировано. 


\section{C.IV-03. Движение по внутренним водным путям порожних судов}

Любое движение грузового судна ВВТ, для которого масса брутто-брутто перевозимых грузов, включая массу оборудования, такого, как контейнеры, съемные кузова и поддоны, равняется нулю; а также любое движение пассажирского судна ВВТ без пассажиров.

Движение судна ВВT, перевозящего порожнее оборудование, такое, как контейнеры, съемные кузова и поддоны, не рассматривается в качестве порожнего рейса.

\section{C.IV-04. Рейс на внутреннем водном транспорте}

Любое движение судна ВВТ из указанного пункта отправления в указанный пункт назначения.

Рейс может подразделяться на ряд этапов или участков.

\section{C.IV-05. Судно-километр}

Единица измерения, соответствующая передвижению судна ВВТ на расстояние в один километр.

Следует учитывать расстояние фактического пробега. Включается передвижение порожних судов. В составе каждая единииа учитывается в качестве одного судна.

\section{C.IV-06. Состав на внутреннем водном транспорте}

Одно или более судов ВВТ, которые не имеют источника двигательной силы и которые буксируются или толкаются одним или более судов ВВТ с источником двигательной силы.

\section{C.IV-07. Транспортное средство-километр}

Единица измерения, соответствующая передвижению отдельного судна ВВТ или состава на расстояние в один километр.

Следует учитывать расстояние фактического пробега. Учитывается движение отдельных порожних судов или состава. 


\section{C.IV-08. Предлагаемый тонно-километр}

Единица измерения, соответствующая перевозке одной тонны на грузовом судне BВT на один километр при осуществлении перевозок, для которых оно первоначально предназначалось.

Следует учитывать расстояние фактического пробега.

\section{C.IV-09. Предлагаемое место-километр}

Единица измерения, соответствующая перевозке одного места на пассажирском судне ВВТ на один километр при осуществлении перевозок, для которых оно первоначально предназначалось.

Следует учитывать расстояние фактического пробега.

\section{C.IV-10. Прибывшее судно ВBT}

Любое груженое или порожнее судно ВВТ, прибывшее в страну по внутреннему водному пути.

Если судно ВВТ прибывает в страну на другом виде транспорта, то считается, что в страну прибыл только активный вид транспорта.

\section{C.IV-11. Выбывшее судно ВВT}

Любое груженое или порожнее судно ВВТ, выбывшее из страны по внутреннему водному пути.

Если судно ВВТ выбывает из страны на другом виде транспорта, то считается, что из страны выббывает только активный вид транспорта.

\section{C.IV-12. Судно ВBT, следующее транзитом}

Любое груженое или порожнее судно ВВТ, которое прибыло в страну или выбыло из нее через разные пункты, независимо от вида транспорта, при условии, что вся перевозка в пределах этой страны осуществлялась по внутреннему водному пути и что в ней не производились ни погрузка, ни выгрузка.

Включаются суда ВВТ, которые на границе этой страны грузятся на другой вид транспорта или выгружаются с него. 


\section{С.V. ИЗМЕРЕНИЕ ОБЪЕМА ПЕРЕВОЗОК}

\section{C.V-01. Перевозка внутренним водным транспортом (ВВT)}

Любая перевозка грузов и/или пассажиров на судне ВВТ по данной сети внутренних водных путей.

Если судно ВВТ перевозится на другом транспортном средстве, то учитывается движение только перевозящего транспортного средства (активный вид транспорта).

\section{C.V-02. Национальная перевозка внутренним водным транспортом}

Перевозка по внутренним водным путям между двумя пунктами (пунктом погрузки/посадки и пунктом разгрузки/высадки), находящимися в одной и той же стране, независимо от страны, в которой зарегистрировано судно ВВТ. Эта перевозка может включать транзитную перевозку через вторую страну.

\section{C.V-03. Каботажная перевозка внутренним водным транспортом}

Национальная перевозка ВВТ, осуществляемая на судне ВВТ, зарегистрированном в другой стране.

\section{C.V-04. Международная перевозка внутренним водным транспортом}

Перевозка по внутренними водным путям между двумя пунктами (пунктом погрузки/посадки и пунктом разгрузки/высадки), находящимися в двух разных странах. Эта перевозка может включать транзитную перевозку через одну или более дополнительных стран.

\section{C.V-05. Перевозка внутренним водным транспортом, осуществляемая третьей стороной}

Международная перевозка ВВТ, осуществляемая на судне ВВТ, зарегистрированном в третьей стране.

Третьей страной является страна, в которой не производится погрузка/посадка, или страна, в которой не производится разгрузка/высадка. 


\section{C.V-06. Транзитная перевозка внутренним водным транспортом}

Перевозка ВВТ по стране между двумя пунктами (пунктом погрузки/посадки и пунктом разгрузки/высадки), причем оба пункта находятся в другой стране или в других странах, при условии, что вся перевозка в пределах данной страны осуществляется на судне ВВТ и что в этой стране не производятся ни погрузка, ни разгрузка.

Включаются суда ВВТ, которые на границе этой страны грузятся на другой вид транспорта или выгружаются с него.

\section{C.V-07. Городская перевозка внутренним водным транспортом}

Перевозка, осуществляемая по внутренним водным путям, находящимся в пределах границ населенного пункта.

В качестве городской перевозки учитываются только те перевозки, которые осуществляются в основном или только по внутренним водным путям, находящимся в пределах границ населенного пункта.

\section{C.V-08. Пассажир внутреннего водного транспорта}

Любое лицо, совершающее поездку на судне ВВТ. Обслуживающий персонал, предназначенный для судов ВВТ, в качестве пассажиров не рассматривается.

\section{C.V-09. Пассажиро-километр на внутреннем водном транспорте}

Единица измерения, соответствующая перевозке одного пассажира по внутреннему водному пути на расстояние в один километр.

Следует учитывать расстояние, которое фактически проехал пассажир.

\section{C.V-10. Цель поездки пассажира внутреннего водного транспорта}

Мотивы поездки:

- работа и учеба (регулярные поездки)

- $\quad$ деловые поездки

- поездки в праздничные дни (каникулы или отпуск)

- прочие поездки (в магазины, с целью отдыха, семейные поездки). 


\section{C.V-11. Пассажир внутреннего водного транспорта, совершивший посадку}

Пассажир, совершивший посадку на судно ВВТ с целью поездки.

Пересадка с одного судна ВВТ на другое рассматривается в качестве посадки после высадки.

\section{C.V-12. Пассажир внутреннего водного транспорта, совершивший высадку}

Пассажир, совершивший высадку с судна ВВТ после поездки.

Пересадка с одного судна ВВТ на другое рассматривается в качестве высадки перед повторной посадкой.

\section{C.V-13. Линия пассажирского сообщения ВBT}

Сочетание пункта посадки и пункта высадки пассажиров, перевозимых по внутренним водным путям, независимо от маршрута следования.

Эти пункты определяются с помощью международных классификационных систем, таких, как НТЕС (Номенклатура территориальных единиц для статистики - Евростат).

\section{C.V-14. Пункт посадки}

В качестве такого пункта рассматривается пункт, в котором пассажир совершает посадку на судно ВВТ с целью поездки.

Пересадка с одного судна ВВТ на другое рассматривается в качестве посадки после высадки.

\section{C.V-15. Пункт высадки}

В качестве такого пункта рассматривается пункт, в котором пассажир совершает высадку с судна ВВТ после поездки.

Пересадка с одного судна ВВТ на другое рассматривается в качестве высадки перед повторной посадкой.

\section{C.V-16. Грузы, перевозимые по внутренним водным путям}

Любые грузы, перевозимые на грузовом судне ВВТ.

К этим грузам относятся все грузовые места и оборудование, такое, как контейнеры, съемные кузова или поддоны. 


\section{C.V-17. Macca}

Учитываемой массой является масса брутто-брутто груза.

Учитываемая масса равна общей массе груза и упаковки, а также массе тары оборудования, такого, как контейнеры, съемные кузова и поддоны.

\section{C.V-18. Тонно-километр на внутреннем водном транспорте}

Единица измерения грузовых перевозок, соответствующая перевозке одной тонны грузов по внутренним водным путям на расстояние в один километр.

Следует учитьвать расстояние фактического пробега.

\section{C.V-19. Типы грузов, перевозимых по внутренним водным путям}

К категории грузов, перевозимых по внутренним водным путям, относятся категории, определенные в номенклатуре НСТ/Р (Стандартная грузовая номенклатура для транспортной статистики/пересмотренный вариант - Евростат) или в номенклатуре КЕТС (Классификация грузов для европейской транспортной статистики ЕЭК ООН).

\section{C.V-20. Опасные грузы}

Классы опасных грузов, перевозимых по внутренним водным путям, определены в Европейском соглашении о международной перевозке опасных грузов по внутренним водным путям (ВОПОГ).

\section{C.V-21. Погруженный груз}

Груз, помещенный на судно ВВТ и перевозимый по внутренним водным путям.

Перегрузка с одного судна ВВТ на другое рассматривается в качестве погрузки после выгрузки. Это также относится к смене толкачей-буксиров или буксиров.

\section{C.V-22. Выгруженный груз}

Груз, снятый с судна ВВТ после перевозки по внутренним водным путям.

Перегрузка с одного судна ВВТ на другое рассматривается в качестве выгрузки перед повторной погрузкой. Это относится также к смене толкачей-буксиров или буксиров. 


\section{C.V-23. Грузы, вывозимые из страны по внутренним водным путям (в отличие от сквозных транзитных грузов, перевозимых по внутренним водным путям)}

Грузы, погруженные на судно ВВТ в данной стране, вывезенные из страны по внутренним водным путям и выгруженные в другой стране.

\section{C.V-24. Грузы, ввозимые в страну по внутренним водным путям (в отличие от сквозных транзитных грузов, перевозимых по внутренним водным путям)}

Грузы, погруженные на судно ВВТ в другой стране, ввезенные в страну по внутренним водным путям и выгруженные в этой стране.

\section{C.V-25. Сквозные транзитные грузы, перевозимые по внутренним водным путям}

Грузы, ввезенные в страну по внутренним водным путям и вывезенные из страны по внутренним водным путям через пункт иной, чем пункт ввоза, после их перевозки через территорию страны только по внутренним водным путям на одном и том же грузовом судне ВВТ.

Перегрузка с одного судна ВВТ на другое и смена толкачей-буксиров или буксиров рассматривается в качестве погрузки/выгрузки.

\section{C.V-26. Линия грузового сообщения ВВТ}

Сочетание пункта погрузки и пункта выгрузки грузов, перевозимых по внутренним водным путям, независимо от маршрута следования.

Эти пункты определяются с помощуью международных классификационных систем, таких, как НТЕС (Номенклатура территориальных единиц для статистики - Евростат).

\section{C.V-27. Пункт погрузки}

В качестве такого пункта рассматривается пункт, в котором грузы грузятся на грузовое судно ВВТ или в котором производится смена толкачей-буксиров или буксиров.

\section{C.V-28. Пункт разгрузки}

В качестве такого пункта рассматривается пункт, в котором грузы выгружаются с грузового судна ВВТ или в котором производится смена толкачей-буксиров или буксиров. 


\section{С.VI. ПОТРЕБЛЕНИЕ ЭНЕРГИИ}

\section{C.VI-01. Потребление энергии на BBT}

Конечное потребление энергии судами ВВТ.

Включается конечное потребление энергии порожними судами ВBT.

\section{C.VI-02. Тонна нефтяного эквивалента (т н.э.)}

Единица изменения потребления энергии (1 т н.э. = 0,041868 Тдж).

Переводные коэффициенты, принятые Международным энергетическим агентством (МЭА) на 1991 год:

$\begin{array}{llr}\text { - } & \text { моторное топливо } & 1,070 \\ \text { - } & \text { газойль/дизельное топливо } & 1,035 \\ \text { - } & \text { тяжелое дизельное топливо } & 0,960 \\ \text { - } & \text { сжиженный нефтяной газ } & 1,130 \\ \text { - } & \text { природньй газ } & 0,917\end{array}$

Переводной коэффиичент, используемый МЭА для электроэнергии, составляет: 1 TBm.ч =0,086 Mm н.э.

\section{C.VI-03. Джоуль}

Единица измерения потребления энергии:

1 тераджоуль $=10^{12}$ Дж $=2,78 \times 10^{5}$ кВт.ч

1 тераджоуль $=23,88459$ т н.э.

\section{C.VI-04. Моторное топливо (бензин)}

Легкое углеводородное топливо для использования в двигателях внутреннего сгорания, исключая топливо для самолетов.

Моторное топливо дистиллируется при температуре от $35^{\circ} \mathrm{C}$ до $215^{\circ} \mathrm{C} u$ подвергается реформингу, каталитическому крекингу или смешивания с какой-либо ароматической фракиией для достижения достаточно высокого октанового числа ( $\geq 80$ ДОЧ).

Теплотворная способность: 44,8 Тдж/1 $000 \mathrm{~m}$. 


\section{C.VI-05. Газойль/дизельное топливо (дистиллятное нефтетопливо)}

Топливо, полученное путем атмосферной перегонки самой низкой фракции сырой нефти.

Газойль/дизельное топливо включает тяжелье газойли, получаемые путем вакуумной перегонки остатков атмосферной перегонки. Газойль/дизельное топливо дистиллируется при температуре $200^{\circ}-380^{\circ}$ С менее чем на $65 \%$ по объему при $250^{\circ} \mathrm{C}$, включая потери, и на $80 \%$ или более при температуре $350^{\circ} \mathrm{C}$. Температура вспьики всегда выле $50^{\circ} \mathrm{C}$, а удельный вес - более 0,81. Тяжелье фракиии, полученные путем смешивания, относятся к газойлю при условии, что их кинематическая вязкость не превышает 25 сСТ, при $40^{\circ} \mathrm{C}$.

Теплотворная способность: 43,3 ТДж/1 $000 \mathrm{~m}$.

\section{D. НЕФТЕПРОВОДНЫЙ ТРАНСПОРТ}

\section{D.I/II. ИНФРАСТРУКТУРА/ТРАНСПОРТНОЕ ОБОРУДОВАНИЕ}

\section{D.I/II-01. Нефтепроводы}

Трубопроводы для транспортировки сырой нефти или очищенных жидких нефтепродуктов путем их перекачки.

Включаются ответвления, а также нефтепроводы между сушей и буровыми платформами в море. Исключаются нефтепроводы, общая протяженность которых составляет менее 50 км или внутренний диаметр которых составляет менее 15 см, и нефтепроводы, используемые только для военных иелей или всецело расположенные в пределах участка промышленного назначения, а также нефтепроводы, всецело расположенные на некотором удалении от берега (т.е. находящиеся только в открытом море). Международные нефтепроводы, общая протяженность которых составляет 50 км или более, включаются, даже если протяженность участка в стране, представляющей информацию, составляет менее 50 км. Нефтепроводы, состоящие из двух (или более) параллельных трубопроводов, следует учитывать дважды (или более).

Следует учитывать только те единицы, которые фактически осуществляют деятельность в течение рассматриваемого периода. Исключаются "спящие" единицы или те единицы, которые не приступили к своей деятельности.

\section{D.I/II-02. Нефтепроводная сеть}

Все нефтепроводы в данном районе.

Территория рассматриваемого района включает ту часть морского дна, которая выделена по концессии. 


\section{D.I/II-03. Пропускная способность нефтепровода}

Максимальный вес продукта в тоннах, который может быть транспортирован по нефтепроводу в течение данного периода.

Пропускная способность трубопровода обычно измеряется в "тысячах баррелей в день". При переводе баррелей в тонны коэффициент пересчета для сырой нефти составляет: 1 тонна = 7,55 барреля (эта величина незначительно изменяется 8 зависимости от типа сырой нефти). Для нефтепродуктов коэффициент пересчета составляет: 1 тонна = 7,5 барреля.

\section{D.III. ПРЕДПРИЯТИЯ, ЭКОНОМИЧЕСКАЯ ДЕЯТЕЛЬНОСТЬ И СФЕРА ЗАНЯТОСТИ}

\section{D.III-01. Предприятие}

Институциональная единица или наименьшее объединение институциональных единиц, которые охватывают и прямо или косвенно контролируют все функции, необходимые для осуществления своей производственной деятельности ${ }^{7}$.

Требования, предъявляемье предприятию, состоят в том, что на предприятие распространяется единый режим собственности или контроля. Однако оно может быть гетерогенным в отношении своей экономической деятельности и своего местоположения.

\section{D.III-02. Нефтепроводное предприятие}

Предприятие, которое создано для осуществления в одном или более местах деятельности по производству услуг по транспортировке нефти по нефтепроводам и основными видами деятельности которого в связи с производством добавленной стоимости является транспортировка по нефтепроводам.

В отраслевых классификациях видов деятельности используется следующее подразделение:

-

- КДЕС/ред.19: 60.30 - Транспортирование по трубопроводам.

7 МСОК/Третий пересмотренный вариант - Международная стандартная отраслевая классификация всех видов экономической деятельности. Статистические документы, серия М, № 4, ред. 3, Организация Объединенных Наций, 1990 года.

8 МСОК/Третий пересмотренный вариант - Международная стандартная отраслевая классификация всех видов экономической деятельности, Статистические документы, серия М, № 4, ред. 3, Организация Объединенных Наций, 1990 год. 
Следует учитывать только те единицы, которые фактически осуществляют деятельность в течение рассматриваемого периода. Исключаются "спящие" единицы или те единиць, которые не приступили к своей деятельности.

\section{D.III-03. Государственное нефтепроводное предприятие}

Нефтепроводное предприятие, которое в основном принадлежит (более $50 \%$ капитала) государству или государственным органам власти и их предприятиям.

\section{D.III-04. Сфера занятости}

Среднее число лиц, работающих в течение данного периода на нефтепроводном предприятии, а также лиц, работающих за пределами этого предприятия, однако входящих в его штат и получающих заработную плату непосредственно от этого предприятия.

\section{D.III-05. Оборот}

Общий объем операций, осуществленных нефтепроводным предприятием за рассматриваемый период. Это соответствует объему рыночных продаж товаров и услуг, предоставленных третьим сторонам. Оборот включает все налоги и пошлины на товары или услуги, произведенные предприятием, без учета НДС, взимаемого предприятием с заказчиков. Он также включает все другие начисления, относимые за счет заказчиков. Из него должны вычитаться снижение цен, возврат части цены и счет заказчиков. Из него должны вычитаться снижение цен, возврат части цены и скидки, а также стоимость возвращенной тары, но не скидки при сделках за наличные.

Оборот не включает продажи основного капитала. Исключаются также эксплуатационные субсидии, полученные от государственных органов.

\section{D.III-06. Поступления}

Суммы, которые выражаются в денежных единицах и которые поступают на доходную часть счета нефтепроводного предприятия.

\section{D.III-07. Типы поступлений}

К основным категориям поступлений относятся:

- $\quad$ поступления от транспортных операций

- суммы, получаемые от государства или от государственных органов.

9 КДЕС/ред.1, Статистическая классификация видов экономической деятельности Европейского сообщества, Официальный бюллетень, № L 83, 3 апреля 1993 года. 
В эту категорию включаются поступления, не связанные с транспортировкой по нефтепроводу, например, финансовые поступления и т.д.

\section{D.III-08. Расходы}

Суммы имеющихся источников, расходуемые нефтепроводным предприятием в связи с транспортной операцией или операцией по предоставлению услуг или с рядом транспортных операций и операций по предоставлению услуг.

\section{D.III-09. Виды расходов}

К основным категориям расходов относятся:

- Издержки на рабочую силу.

Включается заработная плата рабочих и служащих, пенсии, различные отчисления на сочииальные цели и т.д.

- Издержки на материалы и стоимость услуг

Включается закупка других материалов и оплата услуг, предоставляемьх третьими сторонами за вычетом расходов на энергию.

- Расходы на энергию

- $\quad$ налоги

- Финансовые отчисления

- Прочие расходы.

Включаются суммы амортизационных отчислений, резервные фонды и т.д.

\section{D.III-10. Добавленная стоимость}

Валовая продукция нефтепроводного предприятия за вычетом издержек на его промежуточное потребление. Добавленная стоимость отечественного производства всех нефтепроводных предприятий в какой-либо стране равняется их вкладу в ВВП этой страны.

Предполагается, что добавленная стоимость здесь указывается в рыночных иеенах. 


\section{D.III-11. Капиталовложения в материальные активы}

Расходы (закупки и производство за собственный счет) нефтепроводных предприятий на расширение своего основного капитала за счет новых и бывших в употреблении средств производства (товары производственного назначения) за вычетом чистого дохода, полученного от продаж аналогичных подержанных или отбракованных товаров.

Вклад всех нефтепроводных предприятий в валовые вложения в основной капитал страны равняется общему объему их инвестиций в материальные активы за вычетом разницы в цеене покупки и продажи земли.

\section{D.III-12. Капиталовложения в инфраструктуру}

Расходы на строительство новой и расширение существующей инфраструктуры, включая реконструкцию, обновление, капитальный ремонт.

Включаются расходы на насосные станции.

\section{D.III-13. Расходы на содержание инфраструктуры}

Расходы на поддержание инфраструктуры в рабочем состоянии.

Включаются расходы на насоснье станичии.

\section{D.IV/V. ДВИЖЕНИЕ/ИЗМЕРЕНИЕ ОБЬЕМА ПЕРЕВОЗОК}

\section{D.IV/V-01. Транспортировка по нефтепроводу}

Любое перемещение сырой нефти или очищенных жидких нефтепродуктов по данной нефтепроводной сети.

\section{D.IV/V-02. Национальная транспортировка по нефтепроводу}

Транспортировка по нефтепроводу между двумя пунктами (пунктом подачи и пунктом приема), находящимися в одной и той же стране или в той части морского дна, которая относится к этой стране. Эта транспортировка может включать транзитную транспортировку через вторую страну.

\section{D.IV/V-03. Международная транспортировка по нефтепроводу}

Транспортировка по нефтепроводу между двумя пунктами (пунктом подачи и пунктом приема), находящимися в двух различных странах или на тех частях морского дна, которые относятся к ним. Эта транспортировка может включать транзитную транспортировку через одну или более дополнительных стран. 
D.IV/V-04. Грузы, транспортируемые по нефтепроводу.

Любая сырая нефть или очищенные жидкие нефтепродукты, транспортируемые по нефтепроводам.

\section{D.IV/V-05. Тонно-километр на нефтепроводном транспорте}

Единица измерения транспортировки, соответствующая транспортировке одной тонны грузов по нефтепроводу на расстояние в один километр.

Следует учитывать расстояние фактической транспортировки.

\section{D.IV/V-06. Типы грузов, транспортируемых по нефтепроводу.}

К категориям грузов, транспортируемых по нефтепроводу, относятся категории, определенные в номенклатуре НСТ/Р (Стандартная грузовая номенклатура для транспортной статистики/пересмотренный вариант - Евростат) или в номенклатуре КЕТС (Классификация грузов для европейской транспортной статистики ЕЭК ООН).

\section{D.IV/V-07. Предлагаемый тонно-километр}

Единица измерения, соответствующая пропускной способности нефтепровода, измеренной путем транспортировки на расстояние в один километр тонны грузов, которые могут быть транспортированы по нефтепроводу в течение данного периода.

D.IV/V-08. Грузы, транспортируемые из страны по нефтепроводу (в отличие от сквозных транзитных грузов, транспортируемых по нефтепроводу)

Грузы, поданные в нефтепровод в стране или с той части морского дна, которая относится к этой стране, и транспортируемые из этой страны по нефтепроводу.

D.IV/V-09. Грузы, транспортируемые в страну по нефтепроводу (в отличие от сквозных транзитных грузов, транспортируемых по трубопроводу)

Грузы, поданные в нефтепровод в другой стране или с той части морского дна, которая относится к этой стране, и транспортируемые в страну по нефтепроводу и принятые в этой стране.

\section{D.IV/V-10. Сквозные транзитные грузы, транспортируемые по нефтепроводу}

Грузы, которые транспортируются в страну по нефтепроводу и транспортируются из страны по нефтепроводу через пункт, иной, чем пункт ввоза, после их транспортировки через территорию страны только по нефтепроводу. 
Включаются грузы, которые были введены и/или вывезены из рассматриваемой страны на судах после их подачи в трубопровод/приема из трубопровода на гранище.

\section{D.IV/V-11. Нефтепроводная линия}

Сочетание пункта подачи и пункта приема грузов, транспортируемых по нефтепроводу, независимо от маршрута следования.

Эти пункты определяются с помощњю международных классификационных систем, таких, как НТЕС (Номенклатура территориальных единиц для статистики - Евростат).

\section{D.IV/V-12. Пункт подачи}

В качестве такого пункта рассматривается пункт, в котором грузы подаются с помощью насосов в нефтепровод.

\section{D.IV/V-13. Пункт приема}

В качестве такого пункта рассматривается пункт, в котором грузы принимаются с помощью насосов из нефтепровода.

\section{D.VI. ПОТРЕБЛЕНИЕ ЭНЕРГИИ}

\section{D.VI-01. Потребление энергии на нефтепроводном транспорте}

Конечное потребление энергии для транспортировки нефтепродуктов по нефтепроводу.

\section{D.VI-02. Тонна нефтяного эквивалента (т н.э.)}

Единица измерения потребления энергии (1 т н.э. = 0,041868 ТДж).

Переводные коэффициенты, принятые Международным энергетическим агентством (МЭА) на 1991 год:

$\begin{array}{lll}\text { - } & \text { моторное топливо } & 1,070 \\ \text { - } & \text { газойль/дизельное топливо } & 1,035 \\ \text { - } & \text { тяжелое дизельное топливо } & 0,960 \\ \text { - } & \text { сжиженный нефтяной газ } & 1,130 \\ \text { - } & \text { природный газ } & 0,917\end{array}$

Переводной коэффициент, используемый МЭА для электроэнергии, составляет: 1 TBm. $4=0,086 \mathrm{Mm}$ н.э. 
D.VI-03. Джоуль

Единица измерения потребления энергии:

1 тераджоуль $=10^{12}$ Дж $=2,78$ х $10^{5}$ кВт.ч

1 тераджоуль $=23,88459$ т н.э.

\section{D.VI-04. Моторное топливо (бензин)}

Легкое углеводородное топливо для использования в двигателях внутреннего сгорания, исключая топливо для самолетов.

Моторное топливо дистиллируется при температуре $35^{\circ}-215^{\circ} \mathrm{C}$ и подвергается реформингу, каталитическому крекингу или смешиванию с какой-либо ароматической фракиией для достижения достаточно высокого октанового числа ( $\geq 80$ ДОЧ).

Теплотворная способность: 44,8 ТДж/1 $000 \mathrm{~m}$.

\section{D.VI-05. Газойль/дизельное топливо (дистиллятное нефтетопливо)}

Топливо, полученное путем атмосферной перегонки самой низкой фракции сырой нефти.

Газойль/дизельное топливо включает тяжелье газойли, получаемые путем вакуумной повторной перегонки остатков атмосферной перегонки. Газойль/ дизельное топливо дистиллируется при температуре $200^{\circ}-380^{\circ}$ С менее чем на $65 \%$ по объему при $250^{\circ} \mathrm{C}$, включая потери, и на $80 \%$ или более при температуре $350^{\circ} \mathrm{C}$. Температура вспышки всегда выше $50^{\circ} \mathrm{C}$, а удельный вес - более 0,81. Тяжелье фракиии, полученные путем смешивания, относятся к газойлю при условии, что их кинематическая вязкость не превышает $25 \mathrm{cCm} \mathrm{при} 40^{\circ} \mathrm{C}$.

Теплотворная способность: 43,3 ТДж/1 $000 \mathrm{~m}$.

\section{D.VI-06. Сжиженные нефтяные газы (СНГ)}

Легкие фракции углеводородов парафинового ряда, полученные путем перегонки сырой нефти.

СНГ включает пропан и бутан или смесь этих двух углеводородов. Они могут быть сжижены при низком давлении (5-10 атмосфер). В жидком состоянии и при температуре $38^{\circ} \mathrm{C}$ показатель сравнительного давления пара меньше или равен 24,5 бара. Их удельный вес может изменяться в пределах от 0,50 до 0,58. 


\section{D.VI-07. Природный газ}

Природный газ, состоящий в основном из метана, содержащегося в естественных условиях в подземных месторождениях, и сопутствующий сырой нефти и газу, извлекаемому из угольных шахт (угольный газ).

\section{D.VI-08. Электрическая энергия}

Энергия, произведенная на гидроэлектрических, геотермальных, ядерных и обычных тепловых электростанциях, за исключением энергии, произведенной на гидроаккумулирующих станциях, и определенная на основе показателя тепловой способности электроэнергии (3,6 ТДж/ГВт.ч).

\section{Е. МОРСКОЙ ТРАНСПОРТ}

\section{Е.I. ИНФРАСТРУКТУРА}

\section{E.I-01. Прибрежная морская зона}

Прибрежная морская зона обычно определяется как непрерывный участок береговой линии вместе с находящимися в открытом море островами. Она определяется либо в виде одного или нескольких рядов портов вдоль береговой линии, либо исходя из широты и долготы одной или нескольких оконечностей прибрежной зоны.

Могут быть включены берега рек. Для некоторых стран два отдельных участка береговой линии могут учитьваться в качестве одной прибрежной морской зонь, как, например, это имеет место в случае атлантической и тихоокеанской береговых линий в Мексике.

\section{E.I-02. Порт}

Место, оснащенное оборудованием для швартовки торговых судов и погрузки грузов или посадки пассажиров на суда либо выгрузки грузов или высадки пассажиров с судов обычно непосредственно на причал.

\section{E.I-03. Статистический порт}

Статистический порт состоит из одного или более портов, обычно контролируемых одной портовой администрацией, способной регистрировать движение судов и грузов.

\section{E.I-04. Узловой порт}

Порт, предназначенный для обслуживания регулярного глубоководного морского судоходства и регулярного каботажного судоходства. 


\section{Е.I-05. ЛОКОД ООН}

Пятизначный код, в котором первые два знака представляют собой коды стран, предусмотренные в стандарте ИСО 3166, а остальные три знака соответствуют Рекомендации 16, принятой ЕЭК ООН в Женеве, и кодовым обозначениям Евростата для портов, еще не включенных в систему $\mathrm{OOH}$.

\section{E.I-06. Доступность порта с моря}

Доступность порта определяется следующими характеристиками:

i) максимальная длина судна, которое может причалить в порту - в метрах

ii) максимальная осадка судна, которое может причалить в порту - в метрах

iii) ширина и глубина подхода к порту над уровнем малой воды - в метрах

iv) ширина и глубина входного форватера над уровнем малой воды - в метрах

v) приливной период в часах, в течение которого в порт могут входить и из порта могут выходить суда с максимальной осадкой

vi) ограничения по высоте над уровнем полной воды - в метрах (с учетом мостов)

vii) величина прилива - в метрах

\section{E.I-07. Наземные портовые сооружения}

i) общая территория порта - $\mathrm{m}^{2}$

ii) площадки для хранения сырой нефти и нефтепродуктов - м²

iii) площадки для хранения и штабелирования других массовых грузов - м $^{2}$

iv) площадки для штабелирования контейнеров - м $^{2}$ и ТЕУ

v) другие территории - м $^{2}$

vi) автомобильные дороги - м

vii) железнодорожные пути - м

viii) пассажирские терминалы - количество терминалов и количество судов, которые могут причалить у терминала 
Площуадки для хранения и штабелирования массовых грузов включают складские помещения для сухих массовых грузов, лесоматериалов, бумаги, мелких партий грузов и т.д. Железнодорожные пути включают обгонные пути.

\section{E.I-08. Портовые складские площади}

Площадь в м² в портах для складирования по типу сооружения. Высота в метрах для крытых площадок.

i) открытые площадки без надежного заграждения

ii) открытие площадки с надежным заграждением

iii) крытые склады без заграждения

iv) крытые склады с заграждением

Площуадки с надежным заграждением имеют заборы, стены и/или системы наблюдения.

\section{Е.І-09. Протяженность портовых причалов по способу использования}

Общая протяженность причалов в метрах.

Протяженность причалов в метрах по способу использования:

i) многофункциональные причалы

Специализированные причалы:

ii) причалы для горизонтальной обработки грузов (ро-ро)

iii) контейнерные причалы

iv) причалы для обработки прочих генеральных грузов

v) причалы для сухих навалочных грузов

vi) причалы для обработки наливных грузов

vii) пассажирские причалы

viii) рыбоприемные причалы

ix) прочие 


\section{E.I-10. Протяженность портовых причалов по глубине воды}

Протяженность причалов в метрах по глубине воды для судов, пришвартованных у пирса при малой воде.

Возможные диапазоны глубин для ичелей сбора информаџии:

i) до 4 метров

ii) более 4-6 метров

iii) более 6-8метров

iv) более 8-10 метров

v) более 10-12 метров

vi) более 12-14 метров

vii) более 14 метров

\section{E.I-11. Причал для горизонтальной обработки грузов}

Место, где судно ро-ро может швартоваться, загружать и выгружать механические транспортные средства и другие передвижные ролкерные единицы через аппарели с судна на берег и наоборот.

\section{E.I-12. Портовые краны по грузоподъемности}

Количество имеющихся в портах кранов по грузоподъемности.

Возможные классы грузоподъемности:

i) до 10 тонн

ii) более 10-20 тонн

iii) более 20-40 тонн

iv) более 40 тонн

\section{E.I-13. Портовые краны по типу}

Количество имеющихся в портах кранов по типу конструкции.

i) мобильные контейнерные краны 
ii) другие контейнерные краны

Прочие краны

\section{E.I-14. Портовые ремонтные средства}

Ремонтные средства в портах по количеству и максимальному размеру принимаемых судов:
i) сухие доки
ii) плавучие доки
iii) стапели
iv) специализированные судоремонтные причалы

\section{E.I-15. Портовое навигационное оборудование и службы}

Наличие или отсутствие навигационного оборудования и служб: а) в портах и

b) в подходных фарватерах:

i) лоцманская проводка

ii) огни и маяки

iii) радиолокаторы и радиомаяки

iv) система управления движением судов (СУДС) в порту и службы регулирования прибрежного плавания вокруг порта

v) портовые буксиры - количество

vi) буксиры для сопровождения танкеров - количество

vii) бункеровочные средства

viii) швартовочные приспособления

\section{E.I-16. Портовые соединения с внутренними районами и каботажное плавание}

Наличие каботажного плавания и наличие соединений с внутренними районами и расстояние до них от ближайшего въезда в порт в км:

i) каботажное судоходство 

ii) пассажирский терминал
iii) грузовой терминал
iv) автомобильные подъездные дороги
v) соединение с внутренними водными путями
vi) аэропорт

\section{Е.II. ТРАНСПОРТНОЕ ОБОРУДОВАНИЕ (СУДА)}

\section{E.II-01. Мореходное судно}

Плавучее мореходное сооружение, имеющее один или несколько надводных корпусов.

Включаются суда на подводных крыльях, суда на воздушной подушке (экранопланы), катамараны (высокоскоростные суда), нефтебуровые установки, плавучие маяки и мореходные баржи. Включаются суда, находящиеся в ремонте. Исключаются суда, эксплуатируемые исключительно на внутренних водных путях, в защчищенных акваториях или районах, в которых применяются портовые правила, либо в непосредственной близости от них.

\section{E.II-02. Год постройки судна}

Год завершения строительства судна.

\section{E.II-03. Год последнего значительного переоборудования или модификации}

Год, в течение которого на судне в последний раз были произведены значительная модификация или переоборудование, влияющие на его конструкцию.

\section{E.II-04. Сухогрузная мореходная баржа}

Данная категория включает палубные баржи, саморазгружающиеся грунтоотвозные баржи, баржи-лихтеры, беспалубные сухогрузные баржи, палубные сухогрузные баржи и другие сухогрузные баржи.

\section{Е.II-05. Корабль (катер)}

Морское самоходное надводное судно.

Включаются катамараны (высокоскоростные суда). Исключаются суда на подводных крыльях, суда на воздушной подушке (экранопланы), погружаемые аппараты и подводные лодки. Морской корабль эксплуатируется в море, т.е. вне 
сферы применения правил техники безопасности на внутреннем водном транспорте, а именно там, где операторы морских перевозок должны соблюдать правила мореплавания.

\section{E.II-06. Торговое судно}

Судно, предназначенное для перевозки грузов, пассажирских перевозок или специально приспособленное для выполнения конкретных коммерческих функций.

Исключаются военные суда и суда, эксплуатируемые государственными органами и государственными службами. Торговые суда подразделяются на грузовые суда, пассажирские суда и суда прочего назначения, специально предназначенные для выполнения конкретных функций. К судам прочего назначения относятся рыболовные суда и плавучие рыбообрабатывающие заводы, буксиры, дноуглубительные снаряды, научно-исследовательские суда и суда, используемые для обеспечения производства и материально-технической поддержки в прибрежных водах.

На основе классификаџии Евростата (ICST-COM), согласованной с Международной классификацией типов судов ЮНКТАД, определены перечисленные ниже конкретные типь;; в то же время баржи рассматриваются отдельно и в определение торгового судна не включень:

i) Наливное судно

Данная категория включает нефтетанкеры, танкеры-химовозы, танкерыгазовозы, наливные баржи и прочие танкеры. Наливные суда следует далее подразделять на:

а) наливные суда с одиночным корпусом;

b) наливные суда с двойным корпусом.

ii) Балкер

Данная категория включает суда для перевозки массовых грузов/нефти и навалочные суда.

iii) Контейнеровоз

Судно, оснащченное стационарными или переносными ячеистыми направляющими и предназначенное исключительно для перевозки контейнеров.

iv) Специиализированное судно

Судно, специально сконструированное для перевозки особых грузов. 
Данная категория включает автомобилевозы, суда для перевозки скота, суда для перевозки радиоактивного топлива, баржевозы и химовозы.

v) Судно для перевозки генеральных грузов, неспециализированное

Суда, предназначенные для перевозки широкого ассортимента грузов.

Данная категория включает рефрижераторные суда, пассажирские суда ро-ро, контейнерные суда ро-ро, прочие грузовые суда ро-ро, грузопассажирские суда для перевозки генеральных грузов/пассажиров и комбинированные суда для перевозки генеральных грузов/контейнеров.

Данную категорию следует подразделять на:

a) высокоскоростные неспецииализированные суда для перевозки генеральных грузов, отвечающие требованиям Кодекса ВС ИМО, пункт 1.4.30;

b) прочие неспецииализированные суда для перевозки генеральных грузов.

vi) Сухогрузные баржи

Данная категория включает палубные баржи, саморазгружающиеся грунтоотвозные баржи, баржи-лихтеры, беспалубные сухогрузные баржи, палубные сухогрузные баржи и прочие сухогрузные баржи.

vii) Пассажирское судно

Судно, предназначенное спещиально для перевозки более 12 платных пассажиров, как палубных, так и имеющих спальные места.

Данную категорию следует подразделять на:

c) спечиализированные высокоскоростные пассажирские суда, отвечающие требованиям, изложенным в Кодексе ВС ИМО, пункт 1.4.30;

d) прочие пассажсирские суда

Судно, конструкция которого включает одну или несколько палуб и которое предназначено специально для перевозки пассажиров; если на нем не предусмотрено кают для размещения пассажиров (палубных пассажиров) или если не все пассажиры размещуаются в каютах, - при их наличии - его иногда называют "паромом".

Исключаются пассажирские суда ро-ро. 
viii ) Рыбные суда

Данная категория включает рыбопромысловые и рыбообрабатывающие суда.

ix) Эксплуатащия в прибрежной зоне

Данная категория включает буровые и поисково-разведочные суда и прочие вспомогательные суда.

x) Буксиры

Суда, предназначенные для буксирования и/или толкания других судов или прочих плавучих сооружений. Включаются портовые буксиры.

хі) Прочие

Данная категория включает дноуглубительные снаряды, научноисследовательские/гидрографические суда и прочие суда.

Для иелей представления информации в соответствии с директивой 95/64/EC о морской статистике учитываемые типы судов включают наливные суда, сухогрузные суда, контейнеровозы, специиализированные суда, неспециализированные суда для перевозки генеральных грузов и пассажирские cyдa.

\section{E.II-07. Круизное судно}

Пассажирское судно, предназначенное для обеспечения пассажиров полным комплексом туристических услуг. Все пассажиры размещаются в каютах. Включаются средства обслуживания, предназначенные для культурноразвлекательной программы на борту.

Исключаются суда, обеспечивающие обычные паромные перевозки, даже если некоторые пассажиры рассматривают такой рейс в качестве круизного плавания. Кроме того, исключаются также грузовые суда, способные перевозить весьма ограниченное число пассажиров в каютах. Исключаются также суда, предназначенные только для дневных экскурсий.

\section{E.II-08. Национальная принадлежность мореходного судна (государство флага)} Страна и/или территория, где зарегистрировано мореходное судно.

Мореходное судно подпадает под действие морских правил в отночении укомплектования судов командой, стандартов безопасности и консульского представительства его страны и/или территории приписки на борту.

В некоторых страны, например в Норвегии и Дании, существуют "международные" или "открытые" регистры, требования которых отличаются от требований "начионального" регистра. 


\section{E.II-09. Мореходное судно, плавающее под национальным флагом}

Мореходное судно, зарегистрированное в стране-респонденте.

\section{E.II-10. Мореходное судно, плавающее под иностранным флагом}

Мореходное судно, зарегистрированное в стране, не являющейся странойреспондентом.

\section{E.II-11. Торговый флот}

Количество торговых судов дедвейтом свыше 100 тонн, зарегистрированных на данную дату в стране.

Изменения во флоте связаны с полным или частичным изменением типа судов морского флота страны-респондента в результате строительства новых судов, модификачии их типа или грузоподъемности, их передачи другому государству флага или их получения от другого государства флага, списания на слом, повреждения судов или включения в речной регистр либо исключения из него. Включаются суда, находящиеся в ремонте.

\section{E.II-12. Дедвейт}

Дедвейт судна представляет собой разницу в тоннах между водоизмещением судна при осадке на летнюю грузовую марку в воде с удельным весом 1 025, и полной массой судна, т.е. водоизмещением судна в тоннах без груза, топлива, смазочного масла, балластной воды, пресной воды и питьевой воды в танках, расходуемых запасов, а также пассажиров, членов экипажа и их имущества.

\section{E.II-13. Валовой регистровый тоннаж (BPT)}

Валовой регистровый тоннаж - единица измерения размера судна, определяемая в соответствии с положениями Международной конвенции по обмеру судов 1969 года.

До принятия этой Международной конвенџии действовала Конвенция, заключенная в Осло (1947 год), в которой предусматривались иные показатели валового регистрового тоннажа для некоторых типов судов. В ряде случаев валовой регистровый тоннаж соответствующего судна можно определить только на основе этой более старой конвенции.

\section{E.II-14. Система автоматической идентификации}

Система автоматической идентификации представляет собой систему для: 
- $\quad$ автоматической передачи информации, включая название судна, тип, местоположение, курс, скорость, пригодность к судоходству и другую связанную с безопасностью информацию, надлежащим образом оснащенным береговым станциям, другим кораблям и воздушным судам;

- $\quad$ автоматического получения такой информации от аналогичным образом оснащенных судов;

- наблюдения и слежения за движением судов;

- обмена данными с береговыми объектами.

\section{E.II-15. Грузовой контейнер ИСО}

Грузовой контейнер ИСО - предмет транспортного оборудования:

i) имеющий постоянный характер и поэтому достаточно прочный, чтобы быть пригодным для многократного использования;

ii) имеющий специальную конструкцию, обеспечивающую удобную перевозку грузов одним или несколькими видами транспорта без промежуточной перегрузки;

iii) снабженный приспособлениями, позволяющими производить его быструю перегрузку, в частности, передачу с одного вида транспорта на другой;

iv) изготовленный таким образом, чтобы его можно было легко наполнять и опорожнять;

v) имеющий длину 20 футов или более.

Кроме того, контейнеры должны быть итабелируемыми и иметь внутренний объем не менее одного кубического метра. Исключаются съемные кузова.

Хотя контейнерь-платформы, используемые в морских перевозках, не имеют внутреннего объема, их следует относить к контейнерам специального типа и включать в данную категорию. Более подробное описание см. в стандартах ИСО 668 u 1496.

\section{E.II-16. ТЕУ (двадцатифутовый эквивалент)}

Стандартная единица измерения грузовместимости контейнеров, контейнеровозов и контейнерных терминалов. Один двадцатифутовый контейнер ИСО (см. раздел 17 ниже) приравнивается к 1 ТЕУ. 


\section{E.II-17. Размеры контейнеров}

Основные размеры контейнеров:
i) 20-футовый контейнер ИСО (длиной 20 футов и шириной 8 футов)
ii) 40-футовый контейнер (длиной 40 футов и шириной 8 футов)
iii) контейнер ИСО длиной более 20 футов и менее 40 футов
iv) контейнер ИСО длиной более 40 футов
1

Эквивалент ТЕУ

Кроме того, контейнеры стандартной высоты представлены в следующем диапазоне: 8 футов, 8,5 фута и 9,5 фута.

\section{E.II-18. Типы контейнеров}

Основные типы контейнеров, определенные в Руководстве по применению стандартов ИСО 668, касающихся грузовых контейнеров:

i) контейнеры общего назначения;

ii) контейнеры особого назначения:

- контейнер закрытый вентилируемый;

- контейнер открытый сверху;

- $\quad$ контейнер на базе платформы (открытый сбоку);

- $\quad$ контейнер на базе платформы (открытый сбоку) с полной верхней рамой;

- контейнер на базе платформы (открытый сбоку) с неполной верхней рамой и жестко закрепленными торцами;

- $\quad$ контейнер на базе платформы (открытый сбоку) с неполной верхней рамой и складными торцами;

- контейнер-платформа;

iii) контейнеры для специальных грузов:

- изотермический контейнер;

- термоизолированный контейнер;

- рефрижераторный контейнер (с восполняемым хладагентом);

- рефрижераторный контейнер с машинным охлаждением;

- отапливаемый контейнер;

- рефрижераторный и отапливаемый контейнер;

- контейнер-цистерна;

- контейнер для сыпучих грузов; 
контейнер для других видов грузов (например, для перевозки автомобилей, скота и пр.).

\section{E.II-19. Съемный кузов}

Перевозочная единица шириной 2,5 м, достаточно прочная для многократного использования, но не пригодная для захвата сверху или штабелирования более чем в два яруса при загрузке и предназначенная для интермодальных перевозок автомобильным или железнодорожным транспортом, когда по крайней мере один отрезок пути выполняется автомобильным или железнодорожным транспортом.

\section{E.II-20. Передвижная (ролкерная) единица}

Колесное оборудование для перевозки таких грузов, как грузовой автомобиль, прицеп или полуприцеп, которое может быть доставлено своим ходом или на буксире на судно. Включается живой скот.

В это определение включены портовые и судовые трейлеры.

Классификаџии должны соответствовать Рекомендаџии № 21 Европейской экономической комиссии Организаџии Объединенных Наций "Коды для видов груза, упаковки и материала упаковки".

Исключаются транспортные средства, перевозимые в качестве груза, в отличие от средств транспортировки грузов или пассажиров.

\section{E.II-21. Морские трейлеры}

Трейлеры, на которые загружается груз, например поддоны, контейнеры и пр., и которые затем закатываются на суда ро-ро.

Примером таких трейлеров являются трейлерь МАФИ.

\section{Е.II-22. Поддон}

Приподнятая платформа, предназначенная для облегчения операций по подъему и штабелированию грузов.

Поддоны обычно изготавливаются из дерева и имеют стандартные размеры: 1000 мм $x 1200$ мм (ИСО) и 800 мм $x 1200$ мм (ЕКС)

\section{Е.III. ПРЕДПРИЯТИЯ, ЭКОНОМИЧЕСКАЯ ДЕЯТЕЛЬНОСТЬ И СФЕРА ЗАНЯТОСТИ}

\section{E.III-01. Перевозка по найму или за вознаграждение}

Перевозка за плату пассажиров или грузов, производимая за счет третьих лиц. 


\section{E.III-02. Перевозка за собственный счет}

Перевозка, которая осуществляется не по найму и не за вознаграждение.

Такой перевозкой является транспортировка предприятием своего собственного груза без какой-либо связанной с этим финансовой сделки.

\section{Е.III-03. Предприятие}

Институциональная единица или наименьшее объединение институциональных единиц, которые охватывают и прямо или косвенно контролируют все функции, необходимые для осуществления своей производственной деятельности.

Требования, предъявляемые к предприятию, состоят в том, что на предприятие распространяется один режим собственности или контроля. Однако оно может быть гетерогенным в отночении своей экономической деятельности и своего местоположения. Учитываются также те предприятия, которые не имеют наемных служаших. Следует учитывать только те единицы, которые фактически осуществляют деятельность в течение рассматриваемого периода. Исключаются "спящие" единиць или те единиць, которые не приступили к своей деятельности.

\section{E.III-04. Предприятие морского транспорта (судоходная компания)}

Предприятие, которое осуществляет в одном или более местах деятельность по предоставлению услуг по морским перевозкам и основными видами деятельности которого в связи с производством добавленной стоимости являются морские перевозки.

В отраслевых классификациях видов деятельности используется следующее подразделение:

МСОК/ред.3: 6110 - Морской и каботажный водный транспорт

КДЕС/ред..1: 61.10 - Морской и каботажный водный транспорт

Включаются предприятия по управлению эксплуатащией торговых судов по поручению их собственников или арендаторов.

Исключаются порты и другие единиць, обеспечиваюшие вспомогательные и дополнительные транспортные услуги. Эта деятельность относится к подразделу 06 ниже.

\section{E.III-05. Государственное предприятие морского транспорта}

Предприятие морского транспорта, которое в основном принадлежит (более $50 \%$ капитала) государству или государственным органам власти и их предприятиям. 


\section{E.III-06. Портовое предприятие}

Предприятие, которое осуществляет в одном или более местах деятельность по предоставлению портовых услуг и основными видами деятельности которого в связи с производством добавленной стоимости является портовое обслуживание. Исключаются предприятия, занимающиеся обслуживанием портов прогулочных судов.

Включаются сами портовые предприятия, кроме предприятий по обслуживанию портов прогулочных судов. В отраслевых классификациях видов деятельности используется следующее подразделение:

МСОК/ред.3 $3^{\mathbf{1 2}}: 6301$ - Обработка грузов 6303 - Другие вспомогательные виды транспортной деятельности КДЕС/ред.1 $1^{\mathbf{1 3}}$ : 63.11 - Обработка грузов

63.22 - Вспомогательное обслуживание водного транспорта Примечание: подгруппа 63.22 КДЕС включает предприятия по обслуживанию портов прогулочных судов.

\section{E.III-07. Государственное портовое предприятие}

Портовое предприятие, которое в основном принадлежит (более 50\% капитала) государству или государственным органам власти и их предприятиям.

\section{E.III-08. Классификационное общество}

Предприятие, которое устанавливает стандарты проектирования и строительства мореходных судов и занимается надзором за соблюдением этих стандартов на протяжении всего срока эксплуатации судов в целях обеспечения, в интересах общества, высоких технических стандартов конструкции, касающихся проектирования, изготовления, строительства, технического обслуживания, эксплуатации и рабочих характеристик, для повышения безопасности жизни и сохранности имущества на море.

\section{E.III-09. Оборот}

Общий объем операций, осуществленных предприятием за рассматриваемый период. Это соответствует объему рыночных продаж услуг и товаров третьим сторонам. В оборот включается "другая производственная прибыль", например доход от концессий, патентов, торговых знаков и подобных активов. Оборот включает все налоги и пошлины на товары или услуги, произведенные предприятием, без учета НДС, взимаемого предприятием со своих заказчиков. Он также включает все другие начисления, относимые на счет заказчиков. Из него должны вычитаться снижение цен, возврат части цены и скидки, а также стоимость возвращенной тары, но не скидки при сделках за наличные. 
Оборот включает только обычные виды деятельности и поэтому не включает продажи основного капитала. Исключаются также эксплуатационные субсидии, полученные от государственных органов, в том числе от учреждений Европейского союза.

\section{E.III-10. Добавленная стоимость по базисным ценам}

Добавленная стоимость по базисным ценам - оборот предприятия с поправкой на любые изменения в запасах за вычетом расходов на покупку товаров и услуг. Не вычитаются стоимостные поправки, например амортизация.

\section{E.III-11. Добавленная стоимость по факторным издержкам}

Добавленная стоимость по факторным издержкам рассчитывается посредством корректировки добавленной стоимости по базисным ценам с учетом эксплуатационных субсидий, связанных с предоставлением услуг, а также налогов и пошлин, связанных с предоставлением услуг.

В эту поправку включаются субсидии на зарплату и рабочую силу, охрану окружающей среды и дотации на выплату процентов. Например, в поправку включаются такие налоги, как акцизы, гербовые сборы, налоги на финансовые и капитальные операции, налоги на регистрачию транспортных средств и налоги на страховые премии. Из поправки исключаются инвестиционные субсидии и налог на добавленную стоимость.

\section{E.III-12. Общие закупки товаров и услуг}

Включаются все товары и услуги, приобретенные для потребления в процессе предоставления услуг или для перепродажи в таком же состоянии, в каком они были получены. Исключаются капитальные товары. К числу учитываемых товаров относятся такие материалы, как продукты питания для обслуживания на борту, товары для розничной торговли на борту и в других местах, упаковочные материалы, материалы для технического обслуживания и ремонта, канцелярские товары и энергопродукты. Включаются также любые материалы и компоненты для производства капитальных товаров предприятием.

Включаются также любые оплаченные услуги, в том числе платежи третьим сторонам за ремонт и техническое обслуживание, установку, технические исследования, стоимость юридической помощи и бухгалтерских услуг, страховые премии, расходы на собрания акционеров и функционирование руководящих органов, вклад в деятельность предпринимательских и профессиональных органов, услуги почтовой, телефонной и электронной связи, транспортные услуги для персонала, расходы на рекламу, комиссионные, арендная плата, банковские расходы (кроме процентов) и стоимость всех других деловых услуг, предоставляемых третьими сторонами. 
Стоимость закупок оченивается по закупочной цене, включая все налоги и сборы, кроме НДС и других налогов, непосредственно связанных с оборотом.

\section{E.III-13. Расходы на персонал}

Расходы на персонал определяются в виде общего вознаграждения наличными или в натуре, выплачиваемого работодателем работнику (постоянным или временным работникам, а также лицам, работающим на дому) за работу, выполненную последним в течение рассматриваемого периода. Расходы на персонал включают налоги и взносы работодателей в фонды социального обеспечения, удерживаемые производственной единицей, а также обязательные и добровольные отчисления работодателя на социальные цели.

\section{E.III-14. Платежи за долгосрочную и краткосрочную аренду}

Платежи за долгосрочную аренду включают все затраты, связанные с арендой материальных активов за период свыше одного года.

Краткосрочная аренда - это аренда, которая по существу переносит не на арендатора все риски и выгоды, связанные с юридическим владением. Сюда включаются все платежи за краткосрочную аренду товаров, предоставленных в пользование предприятия на основании таких договоров, в том числе выплаты процентов и возврат основной суммы долга.

В морской отрасли в этой связи используются такие термины, как "чартерпартия", "рейсовый чартер", "последующиий рейсовый чартер" и "долгосрочный чартер".

\section{E.III-15. Стоимость материальных активов, приобретенных посредством финансового лизинга}

Аренда определяется как соглашение, на основании которого арендодатель в обмен на арендную плату передает арендатору право пользования предметом собственности на оговоренный срок. Финансовая аренда - это аренда, которая по существу переносит на арендатора все риски и выгоды, связанные с юридическим владением предметом собственности. Право собственности может либо передаваться, либо не передаваться. В этот показатель следует включать стоимость (или оценочную стоимость) всех материальных активов, предоставленных для использования производственной единицей на основании договора финансового лизинга. Стоимость товаров, используемых на основе договоров финансовой аренды, следует включать за исходный период, в котором вступает в силу договор об аренде.

Следует исключать ежегодные платежи за активы, используемые по договору финансового лизинга. Следует также исключать стоимость товаров, используемых по договору об аренде, кроме договоров о финансовой аренде. 


\section{E.III-16. Валовые капиталовложения в материальные активы}

Капиталовложения во все материальные активы, к которым относятся как новые, так и существующие единицы капитального оборудования, срок полезности которых составляет более одного года, включая такие непроизводственные материальные активы, как земля. Все капиталовложения оцениваются до корректировок стоимости и до вычета дохода от реализации. Закупленные товары оцениваются по закупочной цене, т.е. включая транспортные расходы и затраты на установку, сборы, пошлины и другие расходы на передачу права собственности.

Включаются также любое дополнительное оснащение, изменения, усовершенствования и реконструкция, которые продлевают срок службы или повышают производственную мощность капитальных товаров. Исключаются текущие, чьи расходы на техническое обслуживание, а также стоимость и текущие расходы на капитальные товары, используемые по договорам аренды и лизинга. Исключаются капиталовложения в нематериальные и финансовые активье.

\section{E.III-17. Валовые капиталовложения в здания, инфраструктуру и земельные участки}

Расходы на земельные участки, новое строительство, приобретение существующих зданий (в соответствующих случаях включая земельные участки), расширение имеющейся инфраструктуры, в том числе реконструкцию, модернизацию и крупные ремонты.

Включаются внутренние воды, порты и подходы к портам.

\section{E.III-18. Валовые капиталовложения в машины и оборудование, включая суда}

Этот вид расходов охватывает суда, оборудование (компьютеры и т.д.), транспортные средства, включая любые специальные или специализированные транспортные средства, используемые предприятием. В общий показатель включаются любое дополнительное оснащение, изменения, усовершенствования и реконструкция, которые продлевают срок службы или повышают производственную мощность этих капитальных товаров.

Исключаются текущиче расходы на техническое обслуживание.

\section{E.III-19. Продажа материальных активов, включая суда}

Стоимость существующих материальных капитальных товаров, включая суда, проданные третьим сторонам. Продажи регистрируются по фактической полученной цене, а не по балансовой стоимости, после вычета понесенных продавцом расходов на передачу любых прав собственности. 
Исключаются стоимостные корректировки и суммы, полученные от реализации, кроме как посредством продажи.

\section{E.III-20. Сфера занятости}

Число занятых, т.е. общее число лиц, работающих на предприятии (включая работающих собственников, партнеров, работающих регулярно на предприятии, и не оплачиваемых рабочих, занятых на семейном предприятии), а также лиц, занятых за пределами этого предприятия, но входящих в его штат и получающих заработную плату от этого предприятия (например, торговых агентов, персонал, занимающийся доставкой, ремонтные бригады). Включаются лица, отсутствующие в течение короткого периода (например, находящиеся в отпуске по болезни, в оплачиваемом отпуске или в специальном отпуске), а также бастующие, но не лица, отсутствующие в течение неопределенного периода. Включаются также работники, занятые неполный рабочий день, квалифицируемые в качестве таковых на основании законодательства соответствующий страны и входящие в списочный состав предприятия, а также сезонные работники, ученики и работающие на дому лица, входящие в списочный состав предприятия.

В число занятых не входят работники, предоставляемые предприятию другими предприятиями, лица, выполняющие ремонтные работы и работы по текущему обслуживанию на предприятии за счет других предприятий, а также лица, проходящие обязательную военную службу. Вместе с тем в число работников предприятия следует включать лиц, предоставленных в распоряжение предприятия по коммерческим соображениям на основании долгосрочного контракта (например, торговый персонал на пассажирских паромах) в тех случаях, когда они работают на данном предприятии, а не на предприятии, с которым у них заключено трудовое соглашение.

Понятие неоплачиваемых работников, занятых в семейном предприятии, относится к лицам, которые проживают совместно с собственником предприятия и регулярно работают на это предприятие, но которые не имеют договора найма $и$ не получают фиксированного вознаграждения за выполняемую ими работу. Это понятие ограничено теми лицами, которые не включены в списочный состав другого предприятия в качестве своего основного занятия.

Число занятых соответствует числу рабочих мест, определенному в Европейской системе бухгалтерского учета 1995 года (ESA) и измеряется в качестве среднегодового показателя.

\section{E.III-21. Категория занятости - штат предприятия морского транспорта}

Категории занятости на предприятии морского транспорта:

i) лица командного состава

ii) лица рядового состава 
iii) курсанты и другие стажеры

iv) прочий персонал на борту судна, включая работников ресторана и организаторов культурно-развлекательных мероприятий

v) персонал, базирующийся на берегу и занимающийся вопросам управления, продажи, пассажирских и грузовых перевозок и т.д.

\section{E.III-22. Категория занятости - штат портового предприятия}

Категории занятости в портовом предприятии:
i) управление и администрация порта
ii) лоцманы и другой персонал на борту судна
iii) портовые рабочие
iv) технический и обслуживающий персонал
v) прочие

\section{E.IV. ДВИЖЕНИЕ}

\section{E.IV-01. Морское судоходство}

Любое движение мореходного судна в море.

Включается движение без захода в другой порт (перемещения мореходных судов к установкам, расположенным в прибрежных водах, либо для сброса отходов в море или передвижение подводных судов со дна моря к порту).

Включаются перемещения мореходных судов по рекам и морям.

Исключаются перемещения по внутренним водным путям между морскими портами и внутренними водными портами; они относятся к движению по внутренним водным путям. Исключаются внутренние перемещения мореходных судов между различными бассейнами или доками одного и того же порта.

\section{E.IV-02. Регулярное морское сообщение (линейные перевозки)}

Обслуживание, обеспечиваемое морскими судами и осуществляемое по опубликованному графику либо настолько регулярно и часто, чтобы можно было говорить о явно выраженной систематической последовательности. 


\section{E.IV-03. Нерегулярное морское сообщение}

Морское сообщение, помимо регулярного морского сообщения.

\section{E.IV-04. Морской рейс}

Морская перевозка из указанного пункта отправления в указанный пункт назначения.

Рейс можно подразделить на ряд этапов или участков. Включаются рейсы без захода в другой порт из морского порта к установкам, находящимся в прибрежных водах, либо в какое-либо место, расположенное в море. В морском судоходстве морские рейсы иногда называют также переходом или морским переходом.

\section{E.IV-05. Этап морской перевозки}

Этап морской перевозки - перемещение судна непосредственно из одного порта в другой без захода в промежуточный порт.

\section{E.IV-06. Грузовой рейс}

Морской рейс, связанный с перевозкой груза между пунктом погрузки или посадки и портом разгрузки или высадки.

Рейс может предполагать заходы в ряд портов между указанным пунктом отправления и указанным пунктом назначения и включать ряд грузовых рейсов с загрузкой и выгрузкой груза в ряде портов.

\section{E.IV-07. Расстояние от порта до порта}

Для статистических целей расстоянием от порта до порта является фактическое пройденное расстояние.

Может быть представлено приблизительное фактическое расстояние.

\section{E.IV-08. Судно-километр}

Единица измерения, соответствующая перемещению судна на расстояние в один километр.

Следует учитывать расстояние фактического пробега. Включаются перемещения порожних судов. 


\section{E.IV-09. Заход торгового судна в порт}

Торговое судно совершает заход в порт, если оно бросает якорь и швартуется для загрузки или выгрузки груза, для посадки или высадки пассажиров либо в рамках мероприятий по экскурсионному обслуживанию пассажиров.

Исключаются постановка на якорь без какого-либо перемещения груза или пассажиров, а также прохождение порта по траверзу.

\section{E.IV-10. Заход для бункеровки}

Грузовое и пассажирское судно совершает заход в порт для бункеровки, если оно бросает якорь или швартуется в порту для приема бункерного топлива или запасов.

\section{E.IV-11. Другие заходы}

Заходы в порт грузового и пассажирского судна для других целей, помимо вышеуказанных заходов в порт или заходов для бункеровки.

\section{E.IV-12. Прибытие торгового судна}

Прибытие любого торгового судна, совершающего заход в порт на территории страны-респондента.

\section{E.IV-13. Отправление торгового судна}

Отправление любого торгового судна после захода в порт на территории страныреспондента.

\section{E.IV-14. Торговое судно, поставленное на прикол}

Торговое судно ставится на прикол, когда оно швартуется в порту из-за отсутствия работы.

\section{E.IV-15. Контроль со стороны государства порта}

Осмотр в порту торговых судов государством, в котором расположен данный порт, для проверки их мореходных качеств.

\section{E.IV-16. Задержание во время контроля в государстве порта}

Задержание торгового судна, признанного не пригодным к плаванию, в порту во время контроля со стороны государства порта. 


\section{Е.V. ИЗМЕРЕНИЕ ОБЪЕМА ПЕРЕВОЗОК}

\section{E.V-01. Морская перевозка}

Любая перевозка грузов и/или пассажиров с использованием торговых судов, совершающих рейсы полностью или частично в море.

Включаются перевозки без захода в другой порт (перевозки грузов на установки, расположенные в прибрежных водах, либо для сброса отходов в море или транспортировка грузов, извлекаемых со дна моря и выгружаемых в портах). Исключается прием бункерного топлива и запасов на суда в порту, но включаются операции по доставке бункерного топлива на суда в прибрежных зонах.

Включаются перевозки грузов мореходными судами по рекам и морям. Перевозки грузов на судах внутреннего плавания исключаются. (Они относятся к перевозкам по внутренним водным путям.) Исключаются внутренние перевозки грузов между различными бассейнами или доками одного и того же порта.

\section{E.V-02. Коммерческая морская перевозка}

Морская перевозка, производимая в коммерческих целях либо за плату (например, по найму и за вознаграждение), либо за собственный счет предприятия в рамках более широкой экономической деятельности.

\section{E.V-03. Национальная морская перевозка}

Морская перевозка между двумя портами на национальной территории либо морская перевозка без захода в другой порт в пределах национальной территории.

В морском судоходстве национальная морская перевозка также называется каботажной перевозкой. Национальная морская перевозка может осуществляться торговым судном, зарегистрированным в стране-респонденте либо в другой стране.

\section{E.V-04. Международная морская перевозка}

Морская перевозка, помимо национальной морской перевозки.

Включается международная перевозка без захода в другой порт.

\section{E.V-05. Морская перевозка, осуществляемая третьей стороной}

Международная морская перевозка между двумя странами, осуществляемая торговым судном, зарегистрированным в третьей стране.

Третьей страной является страна, помимо страны погрузки/посадки или страны разгрузки/высадки. 


\section{E.V-06. Европейское каботажное судоходство}

Перевозка грузов морем между портами, расположенными в Европе, а также между портами в Европе и портами, расположенными в неевропейских странах, имеющих прибрежную линию на замкнутых морях, граничащих с Европой.

К числу замкнутых морей, граничащих с Европой, относятся Средиземное, Балтийское и Черное моря. Включаются также перевозки в порты и из портов в Исландии.

\section{E.V-07. Морское судоходство (только Европа)}

Перевозка грузов морем, помимо европейского каботажного судоходства.

\section{E.V-08. Перевозка пакетированных грузов}

Перевозка пакетированных грузов - транспортировка груза в интермодальных транспортных единицах, таких, как контейнеры или передвижные (ролкерные) единицы.

Включаются перевозки в съемных кузовах.

\section{E.V-09. Перевозка непакетированных грузов}

Перевозка грузов, помимо перевозки пакетированных грузов.

Такая перевозка включает перевозку наливных и сухих навалочных грузов, лесоматериалов и генерального груза.

\section{E.V-10. Тонно-километр}

Единица измерения, соответствующая перевозке одной тонны груза на торговом судне на расстояние в один километр.

\section{E.V-11. Предлагаемый тонно-километр}

Предлагаемый тонно-километр означает перевозку одной тонны полезной нагрузки на торговом судне на расстоянии в один километр. Количество предлагаемых тонно-километров соответствует грузовместимости судна, умноженной на расстояние от порта до порта применительно ко всем рейсам. Включаются перевозки на баржах. 


\section{E.V-12. Выполненный тонно-километр}

Выполненные тонно-километры рассчитываются суммированием произведений общего количества тонн перевезенного груза за все рейсы на расстояние от порта до порта для каждого рейса.

\section{E.V-13. Использование провозной способности}

Количество выполненных тонно-километров, выраженное в процентах от числа предлагаемых тонно-километров.

\section{E.V-14. Количество тонн груза на борту судна}

Количество тонн груза на борту торгового судна по прибытии в порт или выходе из порта.

\section{E.V-15. ТЕУ-километр}

Единица измерения, соответствующая перевозке одного ТЕУ на расстояние в один километр.

\section{E.V-16. Предлагаемый ТЕУ-километр}

Предлагаемый ТЕУ-километр означает перевозку одного ТЕУ на контейнерном судне на расстояние в один километр. Количество предлагаемых ТЕУ-километров соответствует провозной способности судна в ТЕУ, умноженной на расстояние от порта до порта для всех рейсов.

Провозной способностью в ТЕУ считается заявленная провозная способность, указанная в регистре классификационного общества.

\section{E.V-17. Выполненный ТЕУ-километр}

Количество выполненных ТЕУ-километров, рассчитывается суммированием произведений общего числа перевезенных ТЕУ за все рейсы на расстояние от порта до порта для каждого рейса.

\section{E.V-18. Использование грузоподъемности в ТЕУ}

Количество выполненных ТЕУ-километров, выраженное в процентах от числа предлагаемых ТЕУ-километров.

\section{Е.V-19. ТЕУ на борту судна}

Количество ТЕУ на борту торгового судна по прибытии в порт или выходе из порта. 


\section{E.V-20. Пассажир морского транспорта}

Любое лицо, совершающее морское плавание на торговом судне.

Обслуживающий персонал, приписанный к торговым судам, в качестве пассажиров не рассматривается. Исключаются не заплатившие за рейс члены экипажа, перевозимые на судне, но не приписанные к нему, и грудные дети.

\section{E.V-21. Пассажир круизного судна}

Пассажир, совершающий морское плавание на борту круизного судна.

Исключаются пассажиры судов, обслуживающих дневные экскурсии.

\section{E.V-22. Перевозка пассажира морского транспорта}

Перевозка пассажира из порта, в котором начинается рейс, в порт, в котором он заканчивается. Для некоторых пассажиров, в частности пассажиров круизных судов, речь может идти об одном и том порте.

Учитывается расстояние фактического пробела судна, на котором перевозится пассажир.

\section{E.V-23. Пассажиро-километр}

Единица измерения, соответствующая перевозке одного пассажира на торговом судне на расстояние в один километр.

\section{E.V-24. Предлагаемый пассажиро-километр}

Предлагаемый пассажиро-километр означает единицу пассажировместимости при перевозке на расстояние в один километр.

Количество предлагаемых пассажиро-километров равняется сумме произведений, разрешенной пассажировместимости судна на расстояние от порта до порта для всех рейсов.

За пассажсировместимость принимается заявленная пассажсировместимость, указанная в регистре классификационного общества.

\section{E.V-25. Пассажиры на борту}

Число пассажиров на борту торгового судна по прибытии в порт или выходе из порта. 


\section{E.V-26. Выполненный пассажиро-километр}

Сумма производных, полученных путем умножения числа пассажиров морского транспорта, перевезенных за каждый рейс, на расстояние от порта до порта.

\section{E.V-27. Использование пассажировместимости}

Количество выполненных пассажиро-километров, выраженное в процентах от числа предлагаемых пассажиро-километров.

\section{E.V-28. Цель морской пассажирской перевозки}

Мотивы поездки:

i) работа и учеба (регулярные поездки)

ii) деловые поездки

iii) поездки в праздничные дни (каникулы или отпуск)

iv) прочие поездки (в магазины, с целью отдыха, семейные поездки)

\section{E.V-29. Пассажир морского транспорта, совершивший посадку}

Пассажир, совершающий посадку на торговое судно для осуществления морского пассажирского рейса.

Пересадка с одного торгового судна на другое рассматривается в качестве посадки после высадки. Исключаются пассажиры круизных судов, совершающих экскурсионное круизное плавание.

\section{E.V-30. Пассажир морского транспорта, совершивший высадку}

Пассажир, совершающий высадку с торгового судна в конце морского пассажирского рейса.

Пересадка с одного торгового судна на другое рассматривается в качестве высадки перед повторной посадкой. Исключаются пассажсиры круизных судов, совершающих экскурсионное круизное плавание.

\section{E.V-31. Экскурсионная поездка пассажира круизного судна}

Краткое временное посещение пассажиром круизного судна туристической достопримечательности, связанной с портом, при сохранении каюты на борту судна. 


\section{E.V-32. Линия морских пассажирских перевозок}

Сочетание порта посадки и порта высадки пассажира, перевозимого по морю, независимо от маршрута следования.

Эти порты являются морскими портами (за исключением перевозок река-море, когда они могут быть внутренними водными портами), обозначаемыми соответствующими кодами согласно таким международным классификационным системам, как ЛОКОД ООН (Классификатор портов и других пунктов).

Эти порты можно сгруппировать по их географическому местоположению в соответствии с такими международными классификационными системами, как НТЕС (Номенклатура территориальных единиц для статистики - Евростат).

Если порт посадки и высадки один и тот же, то речь не идет о линии морских перевозок.

\section{E.V-33. Порт посадки}

Порт, в котором пассажир начинает рейс.

Пересадка с одного торгового судна на другое рассматривается в качестве посадки после высадки. Исключаются пассажиры круизных судов, совершающих экскурсионное круизное плавание.

\section{E.V-34. Порт высадки}

Порт, в котором пассажир заканчивает рейс.

Пересадка с одного торгового судна на другое рассматривается в качестве высадки после повторной посадки. Исключаются пассажиры круизных судов, совершающих экскурсионное круизное плавание.

\section{E.V-35. Грузы, перевозимые морским транспортом}

Любые грузы, перевозимые торговыми судами.

К этим грузам относятся все виды упаковки и такое оборудование, как контейнеры, съемные кузова, поддоны или грузовые дорожные транспортные средства.

Включаются почтовые отправления; включаются также грузы, перевозимые на или в вагонах, грузовых автомобилях, прицепах, полуприцепах или баржах.

Напротив, исключаются следующие виды грузов: пассажирские дорожные транспортные средства с водителями, возвращаемые порожние коммерческие транспортные средства и прицепь, топливные цистерны и запасы на судах, рыба, 
перевозимая на рыболовных судах и плавучих рыбообрабатывающих заводах, грузы, перевозимые в пределах одного и того же порта между его различными бассейнами и доками.

\section{E.V-36. Типы груза}

Груз можно классифицировать в зависимости от конструкции самого судна и требуемого погрузочно-разгрузочного оборудования в портах и на судне. Основные категории:
i) наливной груз
ii) сухой навалочный груз
iii) контейнеры
iv) груз для горизонтальной обработки (ро-ро) (самоходные единицы)
v) груз для горизонтальной обработки (ро-ро) (несамоходные единицы)
vi) прочий генеральный груз

\section{Е.V-37. Ло-ло (вертикальная грузообработка)}

Загрузка/разгрузка судна при помощи находящихся на нем грузовых стрел/ грузоподъемных кранов или кранов, базирующихся на берегу.

\section{E.V-38. Контейнерный груз}

Контейнерный груз представляет собой контейнеры с грузом или без груза, загружаемые на суда или выгружаемые с судов, которые перевозят их по морю, с помощью вертикальных способов грузообработки.

\section{E.V-39. Ро-ро (горизонтальная грузообработка)}

Загрузка/разгрузка судна через его ворота/по апарелям при помощи колесных перевозочных средств.

Включается погрузка или выгрузка скота, передвигающегося своим ходом.

\section{E.V-40. Колесный груз}

Колесный груз представляет собой груз, будь то в контейнерах или нет, на колесных грузовых единицах и колесные грузовые единицы, которые закатываются на суда или выкатываются с судов, перевозящих их по морю. 


\section{E.V-41. Масса брутто-брутто грузов}

Общая масса грузов, любой упаковки и масса тары транспортной единицы.

\section{E.V-42. Масса брутто грузов}

Тоннаж перевозимых грузов, включая упаковку, но исключая массу тары транспортных единиц.

\section{E.V-43. Macca тары}

Масса транспортной единицы (например, контейнеров, съемных кузовов и поддонов, предназначенных для помещения в них грузов, а также грузовых дорожных транспортных средств, вагонов или барж, перевозимых морем) до погрузки любого груза.

\section{E.V-44. Категории грузов, перевозимых по морю}

Категории грузов, перевозимых по морю, определены в номенклатурах НСТ (Стандартная грузовая номенклатура для транспортной статистики - Евростат) или КЕТС (Классификация грузов для европейской транспортной статистики ЕЭК ООН).

\section{E.V-45. Опасные грузы}

Классы опасных грузов определены в главе VII Международной конвенции по охране человеческой жизни на море (СОЛАС, 1974 год) с поправками и с учетом положений, содержащихся в Международном кодексе морской перевозки опасных грузов (МКМПОГ).

\section{E.V-46. Перегрузка с судна на судно}

Выгрузка груза с одного торгового судна и его погрузка на другое судно с целью завершения рейса, даже если груз может некоторое время находиться на берегу перед продолжением рейса.

Исключается перевалка на другие виды транспорта.

\section{E.V-47. Погруженный груз}

Груз, помещенный на торговое судно для перевозки по морю.

Перегрузка с одного торгового судна на другое рассматривается в качестве погрузки после разгрузки. Погруженный груз включает национальный груз, перегруженный груз (национальный или иностранный груз, доставленный в порт по морю) и транзитный груз, доставленный наземным транспортом (иностранный 
груз, доставленный в порт автомобильным, железнодорожным, воздушным или внутренним водным транспортом).

\section{E.V-48. Выгруженный груз}

Груз, снятый с торгового судна.

Перегрузка с одного торгового судна на другое рассматривается в качестве разгрузки перед повторной погрузкой.

Выгруженный груз включает начиональный груз, перегруженный груз (национальный или иностранный груз, вывезенный из порта морем) и транзитный груз, вывезенный наземным транспортом (иностранный груз, вывезенный из порта автомобильным, железнодорожным, воздушным или внутренним водным транспортом).

\section{E.V-49. Линия морских грузовых перевозок}

Сочетание порта погрузки и порта выгрузки груза, перевозимого по морю, независимо от маршрута следования.

Эти порты являются морскими портами (за исключением перевозок река-море, когда они могут быть внутренними водными портами), обозначаемыми соответствующими кодами согласно таким международным классификационным системам, как ЛОКОД ООН (Классификатор портов и других пунктов).

Эти порты можно сгруппировать по их географическому местоположению в соответствии с такими международными классификационными системами, как НТЕС (Номенклатура территориальных единии для статистики - Евростат).

\section{E.V-50. Порт погрузки}

Порт, в котором партия груза была погружена на судно, с которого он выгружается в порту-респонденте.

Перегрузка с одного торгового судна на другое рассматривается в качестве погрузки после разгрузки.

\section{E.V-51. Порт разгрузки}

Порт, в котором партия грузов, погруженная на судно в порту-респонденте, должна быть выгружена с этого же судна.

Перегрузка с одного торгового судна на другое рассматривается в качестве разгрузки перед повторной погрузкой. 


\section{Е.VI. ПОТРЕБЛЕНИЕ ЭНЕРГИИ}

\section{E.VI-01. Потребление энергии торговыми судами}

Конечное потребление энергии судами.

Включает конечное потребление энергии порожними судами.

\section{E.VI-02. Тонна нефтяного эквивалента (т н.э.)}

Единица измерения потребления энергии (1 т н.э. = 0,041868 тераджоуля (ТДж).

Переводные коэффициенты, принятые Международным энергетическим агентством (МЭА) на 1991 год:

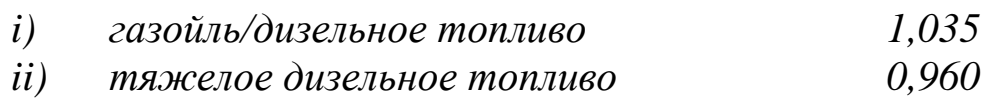

E.VI-03. Джоуль

Единица измерения потребления энергии:

1 тераджоуль $=10^{12}$ Дж $=2,78 \times 10^{5} \kappa$ К‥ч

1 тераджоуль $=23,88459 \mathrm{~m}$ н.э.

\section{E.VI-04. Газойль/дизельное топливо (дистиллятное нефтетопливо)}

Топливо, получаемое путем атмосферной перегонки самой низкой фракции сырой нефти.

Газойль/дизельное топливо включает тяжелье газойли, получаемые путем вакуумной повторной перегонки остатков атмосферной перегонки.

Газойль/дизельное топливо дистиллируется при температуре $200-380^{\circ}$ С менее чем на $65 \%$ по объему при $250^{\circ} \mathrm{C}$, включая потери, и на $80 \%$ или более при температуре $350^{\circ} \mathrm{C}$. Тяжелье фракиии, полученные путем смешивания, относятся к газойлю при условии, что их кинематическая вязкость не превышает 25 сСТ при $40^{\circ} \mathrm{C}$.

Теплотворная способность: 43,3 ТДж/1 $000 \mathrm{~m}$.

\section{E.VI-05. Тяжелое (остаточное) дизельное топливо}

Тяжелые виды топлива, состоящие из остатков перегонки.

Это топливо включает все остаточные дизельные топлива (в том числе полученные путем смешивания). Вязкость тяжелого дизельного топлива 
превышает 25 сСТ при $40^{\circ} \mathrm{C}$. Температура вспьшки всегда выше $50^{\circ} \mathrm{C}$, а удельный вес - более 0,90.

\section{F. ИНТЕРМОДАЛЬНЫЕ ПЕРЕВОЗКИ}

\section{F.I. ВВЕДЕНИЕ}

\section{F.I-01. Интермодальные перевозки}

Перевозки грузов (в одной и той же грузовой единице или на одном и том же транспортном средстве) последовательно используемыми видами транспорта без обработки самих грузов при изменении вида транспорта.

Под транспортным средством подразумевается дорожное транспортное средство, железнодорожное транспортное средство или судно.

Обратные перевозки порожних контейнеров/съемных кузовов и обратное перемещение порожних грузовых дорожных транспортных средств/прищепов сами по себе не являются составной частью интермодальных перевозок, поскольку в этом случае не транспортируется никаких грузов. Такие перевозки ассоциируются с интермодальными перевозками, поэтому целесообразно собирать данные о перемещении порожних транспортных средств вместе с данными об интермодальных перевозках.

Мультимодальные перевозки

* Европейская конференция министров транспорта (ЕКМТ) определяет мультимодальные перевозки как "перевозки грузов по меньшей мере двумя разными видами транспорта". Следовательно, интермодальные перевозки являются отдельным видом мультимодальных перевозок.

* $\quad$ В Конвенции Организации Объединенных Наџий о международных смеманных перевозках грузов используется термин "международная смешанная перевозка", определяемая как "перевозка грузов по меньшей мере двумя разными видами транспорта на основании договора смешанной перевозки из места в одной стране, где грузы поступают в ведение оператора смешанной перевозки, до обусловленного места доставки в другой стране".

Комбинированные перевозки

* Термин "комбинированнье перевозки" используется ЕЭК ООН в том же значении, что и вышеприведенное определение интермодальных перевозок.

* $\quad$ В соответствии с правилами применения Рекомендащии № 19 ЕЭК/ФАЛ "Классификатор видов транспорта" используется следующее определение:

"Комбинированные перевозки: Комбинированное использование транспортных средств, когда одно (ㅁсивное) транспортное средство перевозится на другом 
(активном $)$ транспортном средстве, которое является таковым и потребляет энергию".

* Для целей транспортной политики ЕКМТ ограничивает значение термина "комбинированные перевозки" "интермодальными перевозками, в рамках которых бо́льшая часть европейского рейса приходится на железнодорожный, внутренний водный или морской транспорт и любой первоначальный и/или конечный отрезок пути, на котором используется автомобильный транспорт, является максимально коротким".

\section{F.I-02. (Активный вид)/(Пассивный вид) транспорта}

Перевозка груза с комбинированным использованием двух видов транспорта, когда одно (пассивное) транспортное средство перевозится на другом (активном) транспортном средстве, которое обеспечивает тягу и потребляет энергию (железнодорожный/автомобильный транспорт, морской/автомобильный транспорт, морской/железнодорожный транспорт...).

Понятие контрейлерных перевозок синонимично понятию железнодорожных/ автомобильных перевозок.

\section{F.I-03. Активный вид транспорта/перевозка дорожного транспортного средства с сопровождением}

Перевозка укомплектованного грузового механического дорожного транспортного средства в сопровождении водителя другим видом транспорта (например, морским или железнодорожным).

F.I-04. Активный вид транспорта/перевозка дорожного транспортного средства без сопровождения

Перевозка грузовых механических дорожных транспортных средств или прицепов, не сопровождаемых водителем, другим видом транспорта (например, морским или железнодорожным).

\section{F.I-05. Перевозка контейнеров или съемных кузовов (активным видом транспорта)}

Транспортировка контейнеров или съемных кузовов активным видом транспорта. 


\section{F.II. ОБОРУДОВАНИЕ}

\section{F.II-01. Грузовая единица}

Контейнер, съемный кузов.

Контейнеры-платформы, используемые в морских перевозках, следует рассматривать в качестве контейнеров особого типа, и поэтому они включаются сюда.

\section{F.II-02. Интермодальная транспортная единица (ИTE)}

Контейнер, съемный кузов или полуприцеп/грузовое механическое дорожное транспортное средство, пригодные для интермодальных перевозок.

\section{F.II-03. Контейнер}

Специальный ящик для перевозки груза, укрепленный и пригодный для штабелирования и горизонтального или вертикального перемещения.

В техническом отношении контейнер определяется как: "предмет транспортного оборудования:

a) имеющий постоянный характер и поэтому достаточно прочный, чтобы быть пригодным для многократного использования;

b) имеющий специальную конструкцию, обеспечивающую удобную перевозку грузов одним или несколькими видами транспорта без промежуточной перегрузки;

c) снабженный приспособлениями, позволяющими производить его быструю перегрузку, в частности передачу с одного вида транспорта на другой;

d) изготовленный таким образом, чтобы его можно было легко наполнять и опорожнять;

е) пригодный для штабелирования и

f) имеющий внутренний объем не менее одного кубического метра".

Исключаются съемные кузова.

Хотя контейнеры-платформы, используемые в морских перевозках, не имеют внутреннего объема и поэтому не соответствуют вымеприведенному критерию $f$ ), их следует относить к контейнерам специального типа и включать в данную категорию. 


\section{F.II-04. Размеры контейнеров}

Основные размеры контейнеров:

a) 20-футовый контейнер ИСО: длиной 20 футов и шириной 8 футов;

b) 40-футовый контейнер ИСО: длиной 40 футов и шириной 8 футов;

c) контейнер особо большой емкости (особо крупногабаритный контейнер); и

d) авиационный контейнер (контейнер, соответствующий стандартам, предусмотренным для воздушных перевозок).

Контейнеры, указанные в пунктах а)-с), относятся к категории крупногабаритных контейнеров.

\section{F.II-05. Типы контейнеров}

Основные типы контейнеров, определенные в Руководстве по применению стандартов ИСО, касающихся грузовых контейнеров:

1. контейнеры общего назначения;

2. контейнеры особого назначения:

- контейнер закрытый вентилируемый;

- контейнер открытый сверху;

- $\quad$ контейнер на базе платформы открытый сбоку;

- $\quad$ контейнер на базе платформы открытый сбоку с полной верхней рамой;

- $\quad$ контейнер на базе платформы открытый сбоку с неполной верхней рамой и жестко закрепленными торцами;

- $\quad$ контейнер на базе платформы открытый сбоку с неполной верхней рамой и складными торцами;

- контейнер-платформа;

3. контейнеры для специальных грузов:

- изотермический контейнер;

- термоизолированный контейнер;

- рефрижераторный контейнер (с восполняемым хладагентом);

- $\quad$ рефрижераторный контейнер с машинным охлаждением;

- отапливаемый контейнер;

- рефрижераторный и отапливаемый контейнер;

- контейнер-цистерна;

- контейнер для сыпучих грузов; 
- $\quad$ контейнер для других видов грузов (например, для перевозки автомобилей, скота и пр.); и

- контейнер авиационный.

\section{F.II-06. ТЕУ (двадцатифутовый эквивалент)}

Стандартная единица измерения внутреннего объема контейнеров, контейнеровозов и контейнерных терминалов. ТЕУ равнозначен одному 20-футовому контейнеру ИСО.

Один 40-футовый контейнер ИСО приравнивается к двум ТЕУ.

\section{F.II-07. Съемный кузов}

Перевозочная единица, являющаяся достаточно прочной для многократного использования, но не пригодная для захвата сверху или штабелирования при загрузке и предназначенная для интермодальных перевозок, когда один отрезок пути выполняется автомобильным транспортом.

\section{F.II-08. Контейнер-платформа}

Грузовая платформа без верхней рамы, имеющая такую же длину и ширину, что и база контейнера, и оборудованная верхними и нижними угловыми фитингами.

\section{F.II-09. Поддон}

Приподнятая платформа, предназначенная для облегчения операций по подъему и штабелированию грузов.

Поддоны обычно изготавливаются из дерева и имеют стандартные размеры: 1 000 мм х 1200 мм (ИСО) и 800 мм $x 1200$ мм (ЕКС).

\section{F.II-10. Вагон для интермодальных перевозок}

Вагон, который специально построен или оборудован для перевозки интермодальных транспортных единиц (ИТЕ) или других грузовых дорожных транспортных средств.

\section{F.II-11. Ролкерная единица}

Колесное оборудование для перевозки грузов, таких, как грузовой автомобиль, прицеп или полуприцеп, которое может быть доставлено своим ходом или на буксире на судно или поезд.

В это определение включены портовые и судовые трейлеры. 


\section{ПРЕДМЕТНЫЙ УКАЗАТЕЛЬ}

\section{А. ЖЕЛЕЗНОДОРОЖНЫЙ ТРАНСПОРТ}

Автомотриса A.II-12

Администрация общая А.III-06

Багажный вагон А.II-18

Буксируемое транспортное средство-километр A.IV-09

Буксируемый тонно-километр брутто A.IV-14

Буксируемый тонно-километр брутто-брутто A.IV-13

Бункерный вагон А.II-30

Бурый уголь-лигнит A.VI-09

Вагон

- багажный A.II-18

- $\quad$ бункерный А.ІІ-30

- $\quad$ грузоподъемность А.II-32

- для интермодальных перевозок А.ІІ-31

- $\quad$ изотермический A.II-23

- $\quad$ крытый A.II-22

- $\quad$ ледник А.II-24

- $\quad$ отапливаемый А.II-26

- $\quad$ пассажирский A.II-15

- $\quad$ платформа A.II-28

- $\quad$ полувагон А.II-27

- $\quad$ прицепной, моторвагонного поезда А.II-14

- $\quad$ рефрижератор A.II-25

- товарный A.II-19

- товарный, принадлежащий хозяйствующему объекту на железнодорожном транспорте А.II-20

- $\quad$ товарный, принадлежащий частному владельцу A.II-21

- $\quad$ цистерна A.II-29

Вагон для интермодальных перевозок А.II-31

Вагон-ледник А.II-24

Вагон-километр A.IV-11

Вагон-платформа A.II-28

Вагон-рефрижератор А.II-25

Вагон-цистерна А.ІІ-29

Виды грузовых отправок A.V-17

Виды железнодорожных перевозок A.V-02

Виды занятости А.ІІІ-06

Виды расходов А.III-11

Виды электрической энергии А.I-17

Выгруженный груз A.V-23

Высокоскоростное железнодорожное транспортное средство А.II-02

Высокоскоростное железнодорожное транспортное средство с наклонным 
кузовом А.ІІ-03

Газойль/дизельное топливо (дистиллятное топливо) А.VI-05

Главный путь А.I-08

Грузовая отправка A.V-16

Грузоподъемность вагона А.II-32

Грузы, перевезенные железнодорожным транспортом A.V-15

- выгруженные A.V-23

- $\quad$ погруженные A.V-22

- $\quad$ категории A.V-20

- $\quad$ опасные A.V-21

- сквозные транзитные A.V-26

Джоуль А.VI-03

Добавленная стоимость А.III-12

Дорога железная - А.I-01

Дорожно-эксплуатационные и путевые работы А.ІІІ-06

Железная дорога - А.I-01

Железнодорожная перевозка A.V-01

- $\quad$ виды A.V-02

- $\quad$ международная A.V-04

- $\quad$ национальная A.V-03

- транзитная A.V-05

Железнодорожная сеть А.I-04

Железнодорожное движение A.IV-01

Железнодорожное движение по национальной территории A.IV-03

Железнодорожное предприятие А.III-02

Железнодорожное транспортное средство А.II-01

Железнодорожный габарит приближения строений A.I-07

Железнодорожный путь А.I-05

Железнодорожный транспорт, легкий А.I-03

Занятость

- $\quad$ виды A.III-06

- cфера A.III-05

Изотермический вагон А.II-23

Каменный уголь А.VI-08

Капиталовложения

- $\quad$ в инфраструктуру A.III-14

- $\quad$ в материальные активы A.III-13

- $\quad$ в подвижной состав А.III-15

Категории грузов, перевозимых железнодорожным транспортом A.V-20

Колея

- нормальная A.I-06

- узкая A.I-06

- широкая A.I-06

Коммерческий пассажир железнодорожного транспорта A.V-07

Комплексная компания А.III-04

Крытый вагон А.II-22

Легкий железнодорожный транспорт А.I-03 
Линия A.I-12

- $\quad$ модернизированная высокоскоростная A.I-14

- протяженность эксплуатируемых линий А.I-15

- специализированная высокоскоростная A.I-13

- $\quad$ электрифицированная A.I-16

Линия железнодорожного грузового сообщения A.V-27

Локомотив А.II-07

Максимальная эксплуатационная скорость А.I-18

Маневровая работа A.IV-02

Macca A.V-18

Международная железнодорожная перевозка A.V-04

Международные грузовые перевозки железнодорожным транспортом погрузка (вывозимые грузы) A.V-24

Международные грузовые перевозки железнодорожным транспортом разгрузка (вывозимые грузы) A.V-25

Метро A.I-02

Модернизированная высокоскоростная линия A.I-14

Мотовоз А.II-08

Моторное топливо (бензин) A.VI-04

Национальная железнодорожная перевозка A.V-03

Оборот А.III-07

Общая администрация А.III-06

Обычное высокоскоростное железнодорожное транспортное средство А.II-04

Опасные грузы A.V-21

Отапливаемый вагон А.II-26

Паровоз А.ІІ-09

Пассажир железнодорожного транспорта A.V-06

- $\quad$ коммерческий A.V-07

- поездка A.V-12

- совершивший высадку A.V-11

- совершивший посадку A.V-10

- $\quad$ цель поездки A.V-09

Пассажир железнодорожного транспорта, совершивший высадку A.V-11

Пассажир железнодорожного транспорта, совершивший посадку A.V-10

Пассажиро-километр на железнодорожном транспорте A.V-08

Пассажирский вагон А.II-15

Пассажирское железнодорожное транспортное средство А.II-13

Погруженный груз A.V-22

Подъездные железнодорожные пути A.I-10

Поезд A.IV-05

Поездка пассажира железнодорожного транспорта A.V-12

Поездная секция А.II-05

Поездо-километр A.IV-07

Полувагон A.II-27

Поступления А.III-08

Потребление энергии на железнодорожном транспорте А.VI-01 
Предлагаемое место-километр A.IV-12

Предлагаемый тонно-километр A.IV-10

Прицепной вагон моторвагонного поезда А.II-14

Протяженность эксплуатируемых линий A.I-15

Прочие операции А.III-06

Пункт высадки A.V-14

Пункт погрузки A.V-28

Пункт посадки A.V-13

Пункт разгрузки A.V-29

Путь

- $\quad$ главный A.I-08

- $\quad$ железнодорожный A.I-05

- $\quad$ подъездной железнодорожный A.I-10

- $\quad$ частный подъездной железнодорожный

Расходы А.III-10 электрифицированный А.I-09

- $\quad$ виды А.III-11

- $\quad$ на содержание инфраструктуры А.ІІІ-16

- $\quad$ на содержание подвижного состава А.III-17

Расходы на содержание инфраструктуры А.III-16

Расходы на содержание подвижного состава А.III-17

Рейс железнодорожного транспортного средства A.IV-04

Сеть железнодорожная А.I-04

Сжиженные нефтяные газы (СНГ) А.VI-07

Сквозные транзитные грузы, перевозимые железнодорожным транспортом A.V-26

Служба тяги и подвижного состава А.III-06

Специализированная высокоскоростная линия А.I-13

Сфера занятости А.III-05

Тепловоз А.II-11

Типы поездов A.IV-06

Типы поступлений А.III-09

Товарный вагон А.II-19

Товарный вагон, принадлежащий хозяйствующему субъекту на железнодорожном транспорте А.II-20

Товарный вагон, принадлежащий частному владельцу А.II-21

Тонна нефтяного эквивалента A.VI-02

Тонно-километр на железнодорожном транспорте A.V-19

Транзитная железнодорожная перевозка A.V-05

Транспортное средство

- высокоскоростное железнодорожное А.II-02

- $\quad$ высокоскоростное железнодорожное с наклонным кузовом А.II-03

- $\quad$ железнодорожное А.II-01

- обычное высокоскоростное железнодорожное А.ІІ-04

- пассажирское железнодорожное A.II-13

- $\quad$ тяговое A.II-06

Транспортные операции и управление движением А.III-06

Тяговое транспортное средство А.II-06 
Тяговое транспортное средство-километр A.IV-08

Тяжелое (остаточное) дизельное топливо А.VI-06

Управляющий инфраструктурой А.III-03

Хозяйствующий субъект на железнодорожном транспорте А.III-01

Цель поездки пассажира железнодорожного транспорта A.V-09

Частный подъездной железнодорожный путь А.I-11

Число сидячих и спальных мест А.II-16

Число стоячих мест А.II-17

Ширина колеи А.I-06

Электрифицированная линия А.I-16

Электрифицированный путь А.I-09

Электрическая энергия A.VI-10

Электровоз А.ІІ-10

\section{В. АВТОМОБИЛЬНЫЙ ТРАНСПОРТ}

Автобус дальнего следования или городской автобус В.ІІ-14

Автодорожная перевозка B.V-01

Автодорожная перевозка, осуществляемая третьей стороной B.V-05

Автодорожная транзитная перевозка B.V-06

Автомагистраль B.I-04

Автопоезд В.II-28

Автотранспортное предприятие B.III-04

Альтернативное топливо В.II-36

В пределах населенных пунктов В.VII-16

Велосипед В.II-07

Вид энергии, на котором работает двигатель В.II-35

Водитель В.VII-09

Возраст дорожного транспортного средства В.II-32

Выбывшее дорожное транспортное средство B.IV-10

Выгруженный груз B.V-22

Газойль/дизельное топливо (дистиллятное нефтетопливо) В.VI-05

Городская автодорожная перевозка B.V-07

Городская дорога В.I-05

Государственное автотранспортное предприятие В.ІІІ-08

Грузовое дорожное механическое транспортное средство В.II-20

Грузовое дорожное транспортное средство В.II-18

Грузовой автомобиль В.II-21

Грузоподъемность В.ІІ-30

Грузы

- $\quad$ перевезенные автомобильным транспортом B.V-16

- $\quad$ ввозимые в страну автомобильным транспортом (в отличие от сквозных транзитных грузов, перевозимых автомобильным транспортом) B.V-24

вывозимые из страны автомобильным транспортом (в отличие от сквозных транзитных грузов, перевозимых автомобильным транспортом) B.V-23 
- $\quad$ выгруженные B.V-22

- опасные B.V-20

- $\quad$ погруженные B.V-21

- $\quad$ сквозные транзитные B.V-25

- типы B.V-19

Джоуль B.VI-03

Дизельное топливо/газойль (дистиллятное нефтетопливо) В.VI-05

Дистиллятное нефтетопливо B.VI-05

Добавленная стоимость В.III-15

Дорога - В.I-01

- городская В.I-05

- $\quad$ категории "E" B.I-06

- $\quad$ категория B.I-03

Дорога категории "E" B.I-06

Дорожная сеть B.I-02

Дорожное движение B.IV-01

- $\quad$ городское B.IV-04

- $\quad$ по национальной территории B.IV-02

- $\quad$ порожних транспортных средств B.IV-03

Дорожное механическое транспортное средство В.ІІ-05

Дорожное транспортное средство B.II-01

- $\quad$ возраст B.II-32

- $\quad$ грузовое В.II-18

- $\quad$ иностранное В.II-04

- $\quad$ механическое B.II-05

- $\quad$ национальное В.II-03

- $\quad$ парк B.II-02

- $\quad$ пассажирское B.II-06

- $\quad$ пассажирское дорожное механическое В.II-08

- $\quad$ полная масса B.II-31

- $\quad$ специального назначения B.II-29

Дорожное транспортное средство, следующее транзитом B.IV-11

Дорожно-транспортное происшествие

- $\quad$ без смертельного исхода В.VII-03

- $\quad$ с нанесением травмы B.VII-01

- $\quad$ с участием водителей, которые, согласно протоколу, находились в состоянии алкогольного опьянения, под воздействием наркотиков или медикаментов B.VII-15

- $\quad$ с участием дорожного транспортного средства и пешехода В.VII-12

- с участием нескольких дорожно-транспортных средств B.VII-14

- $\quad$ с участием одного дорожного транспортного средства B.VII-13

- $\quad$ со смертельным исходом В.VII-02

Дорожный тягач B.II-22

Жилой прицеп B.II-13

За пределами населенных пунктов В.VII-17

Иностранное дорожное транспортное средство В.II-04

Каботажная автодорожная перевозка B.V-03 
Капиталовложения

- $\quad$ в дороги В.III-17

- $\quad$ в дорожные транспортные средства В.III-18

- $\quad$ в материальные активы B.III-16

Категория дороги В.I-03

Легкораненые B.VII-08

Линия автомобильного грузового сообщения B.V-26

Линия автомобильного пассажирского сообщения B.V-13

Macca B.V-17

Масса порожнего транспортного средства В.II-34

Международная автодорожная перевозка В.V-04

Мопед B.II-10

Моторное топливо (бензин) B.VI-04

Мотоцикл В.II-11

Национальная автодорожная перевозка В.V-02

Национальное дорожное транспортное средство В.II-03

Оборот В.III-10

Опасные грузы B.V-20

Парк дорожных транспортных средств В.ІІ-02

Пассажир автомобильного транспорта B.V-08

- $\quad$ совершивший высадку B.V-12

- совершивший посадку B.V-11

- $\quad$ цель поездки B.V-10

Пассажир B.VII-10

Пассажиро-километр на автомобильном транспорте B.V-09

Пассажирский автомобиль В.II-12

Пассажирское дорожное механическое транспортное средство В.ІІ-08

Пассажирское дорожное транспортное средство В.II-06

Перевозка

- $\quad$ автодорожная B.V-01

- $\quad$ автодорожная транзитная B.V-06

- $\quad$ автодорожная, осуществляемая третьей стороной B.V-05

- $\quad$ городская автодорожная B.V-07

- $\quad$ за собственный счет B.III-02

- $\quad$ каботажная автодорожная B.V-03

- $\quad$ международная автодорожная B.V-04

- $\quad$ национальная автодорожная B.V-02

- по найму или за вознаграждение B.III-01

Перевозка за собственный счет В.III-02

Перевозка по найму или за вознаграждение В.III-01

Пешеход В.VII-11

Погибший B.VII-05

Погруженный груз B.V-21

Полная масса транспортного средства (разрешенная максимальная масса) B.II-31

Полоса движения B.I-08

Полуприцеп B.II-26 
Поступления В.III-11

типы В.III-12

Потерпевший В.VII-04

Потребление энергии на автомобильном транспорте В.VI-01

Предлагаемое место-километр для сидящего/стоящего пассажира B.IV-08

Предлагаемый тонно-километр B.IV-07

Предприятие В.III-03

- $\quad$ автотранспортное B.III-04

- $\quad$ городского пассажирского автотранспорта В.III-07

- $\quad$ государственное автотранспортное В.III-08

- $\quad$ грузового автотранспорта В.III-06

- $\quad$ пассажирского автотранспорта В.III-05

Предприятие городского пассажирского автотранспорта В.III-07

Предприятие грузового автотранспорта В.ІІІ-06

Предприятие пассажирского автотранспорта В.III-05

Прибывшее дорожное транспортное средство B.IV-09

Прицеп В.II-24

Проезжая часть B.I-07

Прочая дорожная поверхность В.VII-22

Пункт разгрузки B.V-28

Пункт высадки B.V-15

Пункт погрузки B.V-27

Пункт посадки B.V-14

Рабочий объем цилиндров В.II-33

Раненый B.VII-06

Расходы B.III-13

- $\quad$ виды B.III-14

- $\quad$ на содержание дорог В.III-19

- $\quad$ на содержание дорожных транспортных средств В.ІІІ-20

Рейс дорожного транспортного средства B.IV-05

Светлое время суток В.VII-18

Сельскохозяйственный трактор В.II-23

Сельскохозяйственный прицеп В.II-25

Сжиженные нефтяные газы (СНГ) В.VI-06

Сжиженный природный газ (СПГ) В.VI-07

Сквозные транзитные грузы, перевозимые автомобильным транспортом В.V-25

Сочлененное транспортное средство В.ІІ-27

Сумерки (или условия не известны) B.VII-20

Сухая дорожная поверхность B.VII-21

Сфера занятости В.III-09

Темное время суток В.VII-19

Типы грузов, перевозимых автомобильным транспортом B.V-19

Типы кузова грузовых дорожных транспортных средств В.II-19

Типы пассажирских дорожных механических транспортных средств В.II-09

Тонна нефтяного эквивалента (т н.э.) В.VI-02

Тонно-километр на автомобильном транспорте B.V-18

Трамвай B.II-16 
Трамвайный путь B.I-09

Транспортное средство-километр B.IV-06

Транспортное средство специального назначения В.II-29

Троллейбус В.II-15

Тяжелораненый B.VII-07

Число сидячих/спальных мест в автобусах дальнего следования, городских автобусах и троллейбусах В.ІІ-17

Электрическая энергия В.VI-08

\section{С. ВНУТРЕННИЙ ВОДНЫЙ ТРАНСПОРТ (ВВТ)}

Баржа

$$
\begin{array}{ll}
\text { - } & \text { несамоходная наливная С.II-13 } \\
\text { - } & \text { несамоходная С.II-12 } \\
\text { - } & \text { самоходная баржа-толкач С.II-09 } \\
\text { - } & \text { самоходная наливная баржа-толкач C.II-10 } \\
\text { - } & \text { самоходная наливная С.II-08 } \\
\text { - } & \text { самоходная С.II-07 } \\
\text { - } & \text { толкаемая-буксируемая наливная C.II-17 } \\
\text { - } & \text { толкаемая-буксируемая С.II-16 } \\
\text { - } & \text { толкаемая наливная С.II-15 } \\
\text { - } & \text { толкаемая С.II-14 }
\end{array}
$$

Буксир C.II-18

Водный путь C.I-01

$$
\begin{array}{ll}
\text { - } & \text { категории C.I-03 } \\
\text { - } & \text { сеть С.I-07 } \\
\text { - } & \text { судоходный, регулярно используемый для перевозок C.I-08 } \\
& \text { судоходный внутренний водный C.I-02 }
\end{array}
$$

Выбывшее судно ВBT C.IV-11

Выгруженный груз C.V-22

Газойль/дизельное топливо (дистиллятное нефтетопливо) C.VI-05

Год постройки судна С.II-24

Городская перевозка внутренним водным транспортом C.V-07

Грузовое судно С.II-04

Грузоподъемность С.II-21

Грузы, ввозимые в страну по внутренним водным путям (в отличие от сквозных транзитных грузов, перевозимых по внутренним водным путям) C.V-24

Грузы, вывозимые из страны по внутренним водным путям (в отличие от сквозных транзитных грузов, перевозимых по внутренним водным путям) C.V-23

Грузы, перевозимые по внутренним водным путям C.V-16

$$
\begin{array}{ll}
\text { - } & \text { ввозимые в страну C.V-24 } \\
\text { - } & \text { вывозимые из страны C.V-23 } \\
\text { - } & \text { опасные C.V-20 } \\
\text { - } & \text { погруженные C.V-21 } \\
\text { - } & \text { сквозные транзитные C.V-25 }
\end{array}
$$


- типы C.V-19

Движение по внутренним водным путям C.IV-01

- $\quad$ на национальной территории C.IV-02

Джоуль C.VI-03

- $\quad$ порожних судов C.IV-03

Дистиллятное нефтетопливо C.VI-05

Добавленная стоимость С.III-12

Иностранное судно ВВТ C.II-03

Каботажная перевозка внутренним водным транспортом C.V-03

Капиталовложения

- $\quad$ в инфраструктуру С.III-14

- $\quad$ в материальные активы C.III-13

- $\quad$ в суда C.III-15

Категории судоходных внутренних водных путей C.I-03

Линия грузового сообщения BBT C.V-26

Линия пассажирского сообщения ВBT C.V-13

Macca C.V-17

Международная перевозка внутренним водным транспортом C.V-04

Моторное топливо (бензин) C.VI-04

Мощностью (кВт) С.II-23

Национальное судно ВВТ C.II-02

Несамоходная баржа С.II-12

Несамоходная наливная баржа C.II-13

Оборот C.III-07

Опасные грузы C.V-20

Пассажир внутреннего водного транспорта C.V-08

- совершивший высадку C.V-12

- совершивший посадку C.V-11

- цель поездки C.V-10

Пассажир внутреннего водного транспорта, совершивший высадку C.V-12

Пассажир внутреннего водного транспорта, совершивший посадку C.V-11

Пассажировместимость пассажирского судна BВТ C.II-22

Пассажиро-километр на внутреннем водном транспорте C.V-09

Пассажирское судно С.II-05

Перевозка

- $\quad$ внутренним водным транспортом (BBT) C.V-01

- $\quad$ городская C.V-07

- $\quad$ за собственный счет C.III-02

- $\quad$ каботажная C.V-03

- международная C.V-04

- $\quad$ национальная C.V-02

- $\quad$ осуществляемая третьей стороной C.V-05

- по найму или за вознаграждение C.III-01

- транзитная C.V-06

Перевозка внутренним водным транспортом (BBT) C.V-01

Перевозка внутренним водным транспортом, осуществляемая третьей стороной C.V-05 
Перевозка за собственный счет С.III-02

Перевозка по найму или за вознаграждение C.III-01

Погруженный груз C.V-21

Поступления C.III-08

типы C.III-09

Потребление энергии на BBT C.VI-01

Предлагаемое место-километр C.IV-09

Предлагаемый тонно-километр C.IV-08

Предприятие ВBT C.III-04

- $\quad$ государственное C.III-05

Предприятие С.III-03

Прибывшее судно BBT C.IV-10

Пункт высадки C.V-15

Пункт погрузки C.V-27

Пункт разгрузки C.V-28

Пункт посадки C.V-14

Расходы C.III-10

- $\quad$ виды C.III-11

- $\quad$ на содержание инфраструктуры C.III-16

- $\quad$ на содержание судов C.III-17

Рейс на внутреннем водном транспорте C.IV-04

Самоходная баржа С.II-07

Самоходная баржа-толкач C.II-09

Самоходная наливная баржа С.II-08

Самоходная наливная баржа-толкач C.II-10

Самоходное судно типа "река-море" C.II-11

Сеть судоходных внутренних водных путей C.I-07

Сквозные транзитные грузы, перевозимые по внутренним водным путям C.V-25

Состав на внутреннем водном транспорте C.IV-06

Судно ВВТ С.II-01

- выбывшее C.IV-11

- $\quad$ грузовое C.II-04

- $\quad$ иностранное С.II-03

- $\quad$ национальное С.II-02

- $\quad$ пассажирское C.II-05

- $\quad$ прибывшее C.IV-10

- следующее транзитом C.IV-12

Судно ВBT, следующее транзитом C.IV-12

Судно-километр C.IV-05

Судоходная река C.I-04

Судоходное озеро C.I-05

Судоходный внутренний водный путь, регулярно используемый для

перевозок C.I-08

Судоходный внутренний водный путь C.I-02

Судоходный канал C.I-06

Сфера занятости С.III-06 
Типы грузов, перевозимых по внутренним водным путям C.V-19

Толкаемая баржа C.II-14

Толкаемая-буксируемая наливная баржа С.II-17

Толкаемая наливная баржа С.II-15

Толкаемая-буксируемая баржа C.II-16

Толкач C.II-19

Толкач-буксир C.II-20

Тонна нефтяного эквивалента (т н.э.) C.VI-02

Тонно-километр на внутреннем водном транспорте C.V-18

Транзитная перевозка внутренним водным транспортом C.V-06

Транспортное средство-километр C.IV-07

Флот судов внутреннего плавания C.II-06

Цель поездки пассажира внутреннего водного транспорта C.V-10

\section{D. НЕФТЕПРОВОДНЫЙ ТРАНСПОРТ}

Виды расходов D.III-09

Газойль/дизельное топливо (дистиллятное нефтетопливо) D.VI-05

Государственное нефтепроводное предприятие D.III-03

Грузы, транспортируемые в страну по нефтепроводу (в отличие от сквозных транзитных грузов, транспортируемых по трубопроводу) D.IV/V-09

Грузы, транспортируемые из страны по нефтепроводу (в отличие от сквозных транзитных грузов, транспортируемых по нефтепроводу) D.IV/V-08

Грузы, транспортируемые по нефтепроводу D.IV/V-04

- $\quad$ в страну D.IV/V-09

- $\quad$ из страны D.IV/V-08

- $\quad$ сквозные транзитные D.IV/V-10

- типы D.IV/V-06

Джоуль D.VI-03

Дистиллятное нефтетопливо D.VI-05

Добавленная стоимость D.III-10

Капиталовложения

- $\quad$ в инфраструктуру D.III-12

- $\quad$ в материальные активы D.III-11

Международная транспортировка по нефтепроводу

Моторное топливо (бензин) D.VI-04

Национальная транспортировка по нефтепроводу D.IV/V-02

Нефтепроводная линия D.IV/V-11

Нефтепроводная сеть D.I/II-02

Нефтепроводное предприятие D.III-02

Нефтепроводы D.I/II-01

- $\quad$ пропускная способность D.I/II-03

Оборот D.III-05

Поступления D.III-06

типы D.III-07

Потребление энергии на нефтепроводном транспорте D.VI-01

Предлагаемый тонно-километр D.IV/V-07 
Предприятие D.I/II-03

- $\quad$ государственное нефтепроводное D.III-03

- $\quad$ нефтепроводное D.III-02

Природный газ D.VI-07

Пропускная способность нефтепровода D.I/II-03

Пункт подачи D.IV/V-12

Пункт приема D.IV/V-13

Расходы D.III-08

виды D.III-09

Расходы на содержание инфраструктуры D.III-13

Сжиженные нефтяные газы (CHГ) D.VI-06

Сквозные транзитные грузы, транспортируемые по нефтепроводу D.IV/V-10

Сфера занятости D.III-04

Типы грузов, транспортируемых по нефтепроводу D.IV/V-06

Типы поступлений D.III-07

Тонна нефтяного эквивалента (т н.э.) D.VI-02

Тонно-километр на нефтепроводном транспорте D.IV/V-05

Транспортировка по нефтепроводу D.IV/V-01

- международная D.IV/V-03

- $\quad$ национальная D.IV/V-02

Электрическая энергия D.VI-08

\section{Е. МОРСКОЙ ТРАНСПОРТ}

Валовой регистровый тоннаж Е.II-13

Валовые капиталовложения

- $\quad$ в здания, инфраструктуру и земельные участки Е.III-17

- $\quad$ в материальные активы Е.III-16

- $\quad$ в машины и оборудование, включая суда Е.III-18

Вертикальная грузообработка E.V-37

Выгруженный груз E.V-48

Выполненный ТЕУ-километр Е.V-17

Выполненный тонно-километр Е.V-12

Газойль/дизельное топливо (дистиллятное нефтетопливо) Е.VI-04

Год последнего значительного переоборудования или модификации Е.II-03

Год постройки судна Е.II-02

Горизонтальная грузообработка Е.V-39

Государственное портовое предприятие Е.III-07

Государственное предприятие морского транспорта Е.III-05

Государство флага Е.II-08

Грузовой контейнер ИСО Е.II-15

- размеры Е.II-17

- типы Е.II-18

Грузовой рейс Е.IV-06

Грузооборот Е.V-12

Грузы, перевозимые морским транспортом E.V-35 
- $\quad$ выгруженные E.V-48

- $\quad$ категории E.V-44

- $\quad$ колесные E.V-40

- $\quad$ контейнерные E.V-38

- $\quad$ масса брутто E.V-42

- $\quad$ масса брутто-брутто E.V-41

- $\quad$ опасные E.V-45

- $\quad$ погруженные E.V-47

- типы E.V-36

Дедвейт Е.II-12

Джоуль Е.VI-03

Дистиллятное нефтетопливо E.VI-04

Добавленная стоимость

- $\quad$ по базисным ценам Е.III-10

- $\quad$ по факторным издержкам E.III-11

Доступность порта с моря Е.I-06

Европейское каботажное судоходство E.V-06

Задержание во время контроля в государстве порта E.IV-16

Занятость

- $\quad$ категория - персонал портового предприятия Е.III-22

- $\quad$ категория - штат предприятия морского транспорта Е.III-21

- $\quad$ сфера Е.III-20

Заход торгового судна

$$
\begin{array}{ll}
\text { - } & \text { в порт Е.IV-09 } \\
\text { - } & \text { для бункеровки E.IV-10 } \\
\text { - } & \text { другие заходы E.IV-11 }
\end{array}
$$

Использование грузоподъемности в ТЕУ E.V-18

Использование пассажировместимости Е.V-27

Использование провозной способности E.V-13

Категории грузов, перевозимых по морю E.V-44

Категория занятости - штат портового предприятия Е.III-22

Категория занятости - штат предприятия морского транспорта Е.III-21

Классификационное общество Е.III-08

Колесный груз Е.V-40

Количество тонн груза на борту судна E.V-14

Коммерческая морская перевозка E.V-02

Контейнерный груз Е.V-38

Контроль со стороны государства порта E.IV-15

Корабль (катер) Е.II-05

Круизное судно Е.II-07

Линейные перевозки E.IV-02

Линия морских грузовых перевозок E.V-49

Линия морских пассажирских перевозок E.V-32

ЛОКОД ООН Е.I-05

Ло-Ло (вертикальная грузообработка) E.V-37

Macca

$$
\text { брутто грузов Е.V-42 }
$$


- $\quad$ брутто-брутто грузов E.V-41

- $\quad$ тары E.V-43

Международная морская перевозка E.V-04

Мореходное судно Е.II-01

- $\quad$ год последнего значительного переоборудования или модификации Е.II-03

- $\quad$ год постройки Е.II-02

- $\quad$ круизное Е.II-07

- $\quad$ национальная принадлежность (государство флага) Е.II-08

- $\quad$ отправление E.IV-13

- $\quad$ плавающее под иностранным флагом Е.II-10

- плавающее под национальным флагом Е.II-09

- $\quad$ поставленное на прикол E.IV-14

- $\quad$ прибытие E.IV-12

- $\quad$ торговое E.II-06

Мореходное судно, плавающее под иностранным флагом Е.II-10

Мореходное судно, плавающее под национальным флагом Е.II-09

Морская перевозка E.V-01

Морская перевозка, осуществляемая третьей стороной E.V-05

Морской трейлер Е.II-21

Морское судоходство (только Европа) E.V-07

Морское судоходство E.IV-01

Морской пассажирский рейс E.V-22

Морской рейс E.IV-04

Наземные портовые сооружения E.I-07

Национальная морская перевозка E.V-03

Национальная принадлежность мореходного судна Е.II-08

Нерегулярное морское сообщение E.IV-03

Оборот Е.III-09

Общие закупки товаров и услуг Е.III-12

Опасные грузы E.V-45

Отправление торгового судна E.IV-13

Пассажир

- $\quad$ круизного судна E.V-21

- $\quad$ морского транспорта E.V-20

- совершивший высадку E.V-30

- $\quad$ совершивший посадку E.V-29

- $\quad$ число на борту судна E.V-25

- экскурсионная поездка E.V-31

Пассажир круизного судна E.V-21

Пассажир морского транспорта E.V-20

Пассажир морского транспорта, совершивший высадку E.V-30

Пассажир морского транспорта, совершивший посадку E.V-29

Пассажиро-километр E.V-23

- $\quad$ выполненный E.V-26

- $\quad$ предложенный E.V-24 
Перевозка

- $\quad$ за собственный счет Е.III-02

- $\quad$ коммерческая морская E.V-02

- $\quad$ линия морских грузовых E.V-49

- $\quad$ линия морских пассажирских E.V-32

- $\quad$ международная морская E.V-04

- $\quad$ морская Е.V-01

- $\quad$ морская, осуществляемая третьей стороной E.V-05

- $\quad$ национальная морская E.V-03

- $\quad$ непакетированных грузов Е.V-09

- $\quad$ нерегулярное морское сообщение E.IV-03

- $\quad$ пакетированных грузов Е.V-04

- $\quad$ по найму или за вознаграждение E.III-01

- $\quad$ регулярное морское сообщение (линейные перевозки) E.IV-02

- $\quad$ этап E.IV-05

Перевозка за собственный счет Е.III-02

Перевозка непакетированных грузов E.V-09

Перевозка пакетированных грузов E.V-08

Перевозка по найму или за вознаграждение Е.III-01

Перегрузка с судна на судно E.V-46

Передвижная (ролкерная) единица Е.II-20

Платежи за долгосрочную и краткосрочную аренду Е.III-14

Погруженный груз E.V-47

Поддон Е.II-22

Порт E.I-02

$$
\begin{array}{ll}
- & \text { доступность с моря E.I-06 } \\
\text { - } & \text { статистический Е.I-03 } \\
\text { - } & \text { узловой E.I-04 }
\end{array}
$$

Порт высадки Е.V-34

Порт погрузки E.V-50

Порт посадки Е.V-33

Порт разгрузки E.V-51

Портовое навигационное оборудование и службы Е.I-15

Портовое предприятие Е.III-06

Портовые краны

$$
\begin{array}{ll}
\text { - } & \text { по грузоподъемности E.I-12 } \\
\text { - } & \text { по типу Е.I-13 }
\end{array}
$$

Портовые ремонтные средства Е.I-14

Портовые складские площади Е.I-08

Портовые соединения с внутренними районами и каботажное плавание Е.I-16

Потребление энергии торговыми судами E.VI-01

Предлагаемый ТЕУ-километр Е.V-16

Предлагаемый тонно-километр Е.V-11

Предприятие Е.III-03

$$
\begin{array}{ll}
\text { - } & \text { государственное Е.III-05 } \\
\text { - } & \text { государственное портовое Е.III-07 } \\
\text { - } & \text { морского транспорта (судоходная компания) E.III-04 }
\end{array}
$$


- $\quad$ портовое Е.ІІІ-06

Предприятие морского транспорта (судоходная компания) Е.III-04

Прибрежная морская зона Е.I-01

Прибытие торгового судна E.IV-12

Причал для горизонтальной обработки грузов (Рo-Po) E.I-11

Продажа материальных активов, включая суда Е.III-19

Протяженность портовых причалов по глубине воды Е.I-10

Протяженность портовых причалов по способу использования Е.I-09

Размеры контейнеров Е.II-17

Расстояние от порта до порта E.IV-07

Расходы на персонал Е.III-13

Регулярное морское сообщение (линейные перевозки) E.IV-02

Ро-ро (горизонтальная грузообработка) E.V-39

Система автоматической идентификации Е.II-14

Статистический порт Е.I-03

Стоимость материальных активов, приобретенных посредством финансового лизинга Е.III-15

Судно-километр E.IV-08

Судоходная компания Е.III-04

Сухогрузная мореходная баржа Е.II-04

Сфера занятости Е.III-20

Съемный кузов Е.II-19

ТЕУ (20-футовый эквивалент) Е.II-16

ТЕУ-километр Е.V-15

- $\quad$ выполненный Е.V-17

- $\quad$ использование грузоподъемности в ТЕУ E.V-18

- $\quad$ на борту судна E.V-19

- $\quad$ предлагаемый E.V-16

ТЕУ на борту судна E.V-19

Типы груза E.V-36

Типы контейнеров Е.II-18

Тонна нефтяного эквивалента (т.н.э.) Е.VI-02

Тонно-километр Е.V-10

- $\quad$ выполненный E.V-12

- $\quad$ предложенный E.V-11

Торговое судно Е.II-06

Торговое судно, поставленное на прикол E.IV-14

Торговый флот Е.II-11

Тяжелое (остаточное) дизельное топливо Е.VI-05

Узловой порт Е.I-04

Цель морской пассажирской перевозки E.V-28

Число пассажиров на борту судна E.V-25

Экскурсионная поездка пассажира круизного судна E.V-31

Этап морской перевозки E.IV-05 


\section{F. ИНТЕРМОДАЛЬНЫЕ ПЕРЕВОЗКИ}

Активный вид (пассивный вид) транспорта F.I-02

Активный вид транспорта/перевозка дорожного транспортного средства без сопровождения F.I-04

Активный вид транспорта/перевозка дорожного транспортного средства с сопровождением F.I-03

Вагон для интермодальных перевозок F.II-10

Грузовая единица F.II-01

Двадцатифутовый эквивалент F.II-06

Интермодальная транспортная единица (ИТЕ) F.II-02

Интермодальные перевозки F.I-01

Комбинированные перевозки F.I-01

Контейнер F.II-03

$$
\begin{array}{ll}
\text { - } & \text { размеры F.II-04 } \\
\text { - } & \text { типы F.II-05 }
\end{array}
$$

Контейнер-платформа F.II-08

Кузов, съемный F.II-07

Мультимодальные перевозки F.I-01

Пассивный вид (активный вид) F.I-02

Перевозка контейнеров или съемных кузовов (активным видом транспорта) F.I-05

Перевозка

- $\quad$ дорожного транспортного средства без сопровождения F.II-04

- $\quad$ дорожного транспортного средства с сопровождением F.II-03

- интермодальная F.I-01

- комбинированная F.I-01

- контейнеров или съемных кузовов F.II-05

- мультимодальная F.I-01

- $\quad$ смешанная F.I-01

Поддон F.II-09

Размеры контейнеров F.II-04

Ролкерная единица F.II-11

Смешанные перевозки F.I-01

Съемный кузов F.II-07

ТЕУ (двадцатифутовый эквивалент) F.II-06

Типы контейнеров F.II-05 